Universidade de São Paulo

Faculdade de Saúde Pública

RAFAEL AUGUSTO TAMASAUSKAS TORRES

Gestão do tempo no cotidiano de médicos residentes

de Clínica Médica em um hospital público universitário de São Paulo, Brasil.

São Paulo 


\title{
Gestão do tempo no cotidiano de médicos residentes de Clínica Médica em um hospital público universitário de São Paulo, Brasil.
}

\author{
Versão Corrigida
}

Dissertação de Mestrado para o Programa de PósGraduação em Saúde Pública para obtenção do título de Mestre em Ciências.

Área de Concentração: Saúde do Trabalhador

Orientadora: Prof. ${ }^{a}$ Dra. Frida Marina Fischer

São Paulo

2018 
Autorizo a reprodução e divulgação total ou parcial deste trabalho, por qualquer meio convencional ou eletrönico, para fins de estudo e pesquisa, desde que citada a fonte.

Torres, Rafael Auguato Tamanauskan

Gentso do tempo no cotidiano de mfidicos reaidentes de Clinica Nedica em um houpital pablico univeraitsrio de Săo Paulo, Brasil. / Rafael Auguato Tamasaunkan Torrea; orientadora Frida Marina Fiacher. -. Săo Paulo, 2018.

$106 \mathrm{p}$.

Diseertaç5o (Meatrado) -. Faculdade de Salude Pablica da Univereidade de Săo Paulo, 2018.

1. Reaidencia Medica. 2. Trabalho em turnoa. 3. Geatso do tempo. I. Fiecher, Prida Marina, orient. II. Titulo. 


\section{AGRADECIMENTOS}

À Profa. Dra. Frida Marina Fischer, por toda paciência e orientação ao longo deste trabalho. À Dra. Andrea Aparecida da Luz, por todo apoio e auxílio ao longo deste projeto.

Aos professores Dra. Maria da Penha Vasconcellos, Dra. Elaine Cristina Marqueze, Dr. João Silvestre da Silva Júnior e Dra. Cristiane Cabral, pelas contribuições ao trabalho.

À Faculdade de Saúde Púbica da Universidade de São Paulo, pela oportunidade de realização do curso de mestrado.

À Comissão de Residência Médica, em especial Dra. Vera Hermina Kalika Koch, por permitir a realização deste estudo.

Aos participantes desta pesquisa, pelo tempo e dedicação à este projeto.

À Cássia Moura dos Santos pelo auxílio na coleta de dados.

Aos professores Dr. René Mendes, Dra. Marcia Bandini e Dr. Eduardo Costa Sá, por todos os ensinamentos e estímulo para realização deste curso.

À minha família, em especial minha esposa e minha mãe, pelo apoio ao longo desta jornada. 


\section{SUMÁRIO}

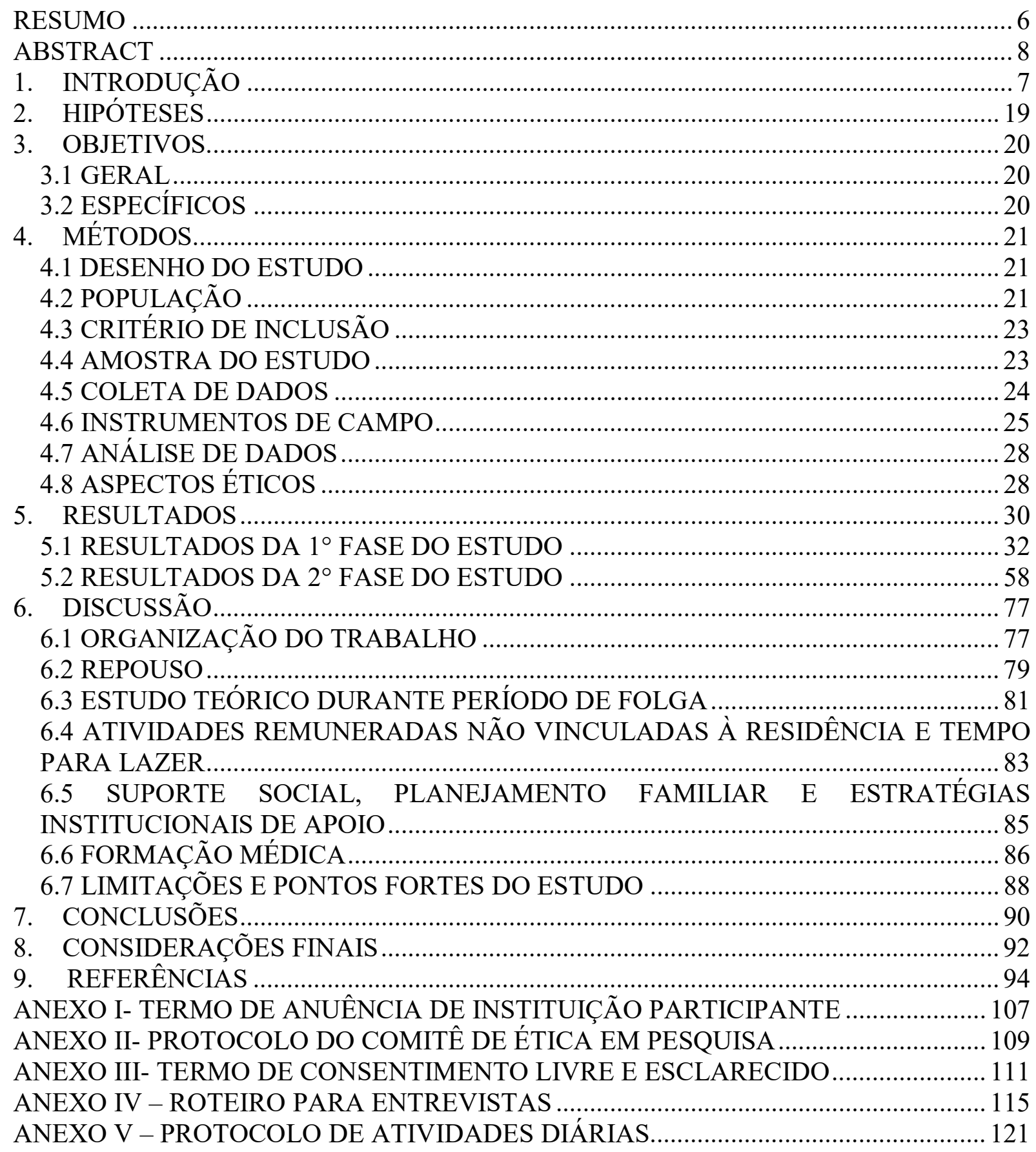




\section{RESUMO}

TORRES, Rafael Augusto Tamasauskas. Estratégias para gestão do tempo no cotidiano de médicos residentes de Clínica Médica em um hospital público universitário de São Paulo, Brasil. 2018. 106 f. Dissertação (Mestrado em Saúde Pública) - Faculdade de Saúde Pública, Universidade de São Paulo; 2018.

Introdução: A formação médica é um processo complexo que envolve a aquisição de diversas competências. Este processo desenvolve-se durante a graduação e tende a consolidarse na residência médica. Embora seja uma forma reconhecida de capacitação profissional, críticas são feitas em relação à sobrecarga de trabalho, carga horária excessiva e privação de sono. Objetivo: Descrever e analisar estratégias de gestão do tempo no cotidiano de médicos residentes de Clínica Médica em um hospital universitário de São Paulo, Brasil. Métodos: Na $1^{\circ}$ fase foram realizadas 8 entrevistas com médicos residentes abordando aspectos de vida pessoal, familiar, empregos, estudo teórico e atividades práticas. Realizada análise de conteúdo com auxílio do programa MaxQDA. Na $2^{\circ}$ fase foram preenchidos protocolos de atividades diárias por 7 residentes, 5 no estágio de avaliação pré-operatória e 2 no estágio do pronto-socorro de clínica médica. Calculadas médias individuais e em grupo destes dados. Resultados: Após análise de conteúdo 5 categorias foram selecionadas: a) Organização do trabalho durante as atividades práticas da residência; b) Atividade para aprendizado ou atividade profissional?; c) Moradia, planejamento financeiro e atividades domésticas; d) Tempo para lazer e relacionamentos interpessoais; e) Planejamento familiar / filhos; f) Repouso / Sono. Há relatos de atividades remuneradas não vinculadas a residência, diminuindo o tempo previsto para repouso, estudo ou lazer. Nos períodos de plantões noturnos há uma piora do convívio social e familiar devido ao deslocamento do repouso para o período diurno. $\mathrm{O}$ grupo no estágio de avaliação pré-operatório, em dias de atividade na residência, apresentou mediana de tempo diário em atividade de 7,5h; em repouso noturno $6,7 \mathrm{~h}$; em estudo teórico $2,2 \mathrm{~h}$ e no repouso diurno $0 \mathrm{~h}$. Para o grupo no estágio do prontosocorro de clínica médica, nos dias de atividades diurnas esses tempos foram 13,0h; 7,0h; 0h e $0 \mathrm{~h}$, respectivamente. Para os dias de atividades noturnas, foram $12,5 \mathrm{~h} ; 0 \mathrm{~h} ; 0 \mathrm{~h} \mathrm{e} 7,1 \mathrm{~h}$, respectivamente. Discussão: Há diferenças entre trabalho prescrito e real pois a duração da jornada é superior ao previsto em alguns estágios, devido a intercorrências e visitas em enfermarias. $\mathrm{O}$ aumento do período da residência permitiria diminuição da carga horária diária, mas impactaria no planejamento pessoal destes médicos. Há uma privação parcial de sono que piora em estágios com plantões, interferindo inclusive em relacionamentos sociais, principalmente fora do ambiente de trabalho. Durante plantões noturnos há um pior desempenho das atividades, incluindo incidentes como interpretação errônea de exames e erros de prescrição médica. Conclusões: Os residentes vivenciam um período de aprendizado intenso, mas que exige uma carga horária elevada e trabalho complexo, com períodos de plantões noturnos e em fins de semana. Optam por adiar o momento da maternidade /paternidade para centrar a atenção nos estudos, seja para a prova de título da especialidade, quanto para um novo concurso de residência. Há diversas estratégias adotadas para gestão do tempo: residir próximo ao hospital; auxílio das atividades domésticas por diaristas; realizar 
refeições nos restaurantes do hospital; adiamento da maternidade/paternidade; apoio social centrado no convívio com outros residentes e supervisores.

Palavras-chave: Residência médica. Trabalho em turnos. Gestão do tempo. 


\begin{abstract}
TORRES, Rafael Augusto Tamasauskas. Time managing strategies in the daily routine of Internal Medicine residents in a public university hospital in São Paulo, Brazil. 2018. 106 pp. Dissertation (Master's degree in Public Health) - School of Public Health, University of São Paulo; 2018.
\end{abstract}

Introduction: Medical education concerns in a complex process which involves acquisition of a wide range of skills. This process develops from undergraduate education to medical residency, when it consolidates. As long as it is a recognized way of training, criticisms are made due to work overload, excessive working hours, and sleep deprivation. Objective: To describe and analyze strategies of time management in the daily life of Internal Medicine residents in a university hospital in São Paulo, Brazil. Methods: In the first phase, 8 interviews were conducted with resident physicians addressing aspects of personal and family life, jobs, theoretical study and practical activities. Data analysis was carried out using the MaxQDA program. In the second phase, protocols of daily activities were filled by 7 residents, 5 in the preoperative evaluation internship and 2 in the adult emergency room internship. Individual and group averages of the time spent with residency activities, rest, leisure, study and other jobs were performed. Results: After data analysis, 5 categories were selected: a) Organization of work during the practical activities of the residence; b) Activity for learning or professional activity?; c) Housing, financial planning and domestic activities; d) Time for leisure and interpersonal relationships; e) Family planning / children; f) Rest / Sleep. Paid activities beside the residency program were reported and responsible for decreasing the rest, study and leisure time. During the night shifts was noticed a decrease of social and family ties due to the change of resting hours towards the daytime. For the group in the preoperative evaluation internship, were identified the median daily time in activity of $7,5 \mathrm{~h}$ of working time, $6,7 \mathrm{~h}$ of night rest, $2,2 \mathrm{~h}$ of internal medicine theory study and $0 \mathrm{~h}$ of daytime rest. For the adult emergency room internship group, the activities hours were 13,0h; 7,0h; $0 \mathrm{~h}$ and $0 \mathrm{~h}$, respectively. Lastly, for night shifts routines, the activities hours were 12,5h; 0h; $0 \mathrm{~h}$ and 7,1h respectively. Discussion: There are differences between described and factual work since the working shift length is higher than anticipated in some internships, due to intercurrences and medical visits in wards. Increasing the duration of residency programs would let a decrease of daily working hours, but would impact in the personal planning of resident doctors. Sleep deprivation gets worse in internships composed by shift hours, impacting in social relationships outside work. During working shifts is notable a worse performance, being reported incidents such as lab tests misreading and prescription mistakes. Conclusions: Resident physicians experience a period of intense learning that requires a high and complex workload with night and weekend shifts. For that, maternity/paternity is postponed to aim studies for board or fellowship exams. There are various strategies used to improve time management: housing around hospital, support of maid services at home, oncampus feeding and social support centered on other residents and medical staff.

Keywords: Medical residency. Shift work. Time management. 


\section{INTRODUÇÃO}

1.1 Breve panorama do serviço médico no Brasil

Em 1910, no Brasil, haviam 13.270 médicos inscritos no Conselho Federal de Medicina. É nítido o aumento do número de médicos nos últimos anos sendo que em 2015 haviam 432.870 médicos registrados neste conselho (SHEFFER; BIANCARELLI; CASSENOTE, 2015). Neste mesmo período a população brasileira passou de 17,4 milhões para 204 milhões de pessoas (INSTITUTO BRASILEIRO DE GEOGRAFIA E ESTATÍSTICA, 2018).

Dados de aproximadamente 15.000 médicos brasileiros (MACHADO, 1997) mostraram que $80 \%$ destes consideravam a profissão desgastante. Entre os principais motivos (auto referidos) estão o excesso de trabalho multiemprego, baixa remuneração, más condições de trabalho, responsabilidade profissional elevada, conflito / cobrança da população e perda de autonomia.

Apesar desse quadro, trata-se de uma população de difícil estudo devido à dificuldade de acesso a mesma (CABANA et al., 2007), ao auto tratamento e consultas de corredor que ocorrem dentro da categoria e à chamada "Síndrome da Invulnerabilidade Médica", ou seja, o sentimento de que não adoecerá, causando negligência com o cuidado de sua própria saúde (CLEVER, 1990).

Segundo SHEFFER; BIANCARELLI; CASSENOTE (2015), após estudar os dados do Conselho Federal de Medicina e realizar um inquérito nacional com aproximadamente 2.400 médicos, há uma tendência de feminização e juvenescimento desta classe, sendo que alguns dados chamam atenção: 
- 55\% dos médicos concentram-se na região sudeste do país;

- 59\% dos médicos tem títulos de especialista, sendo que na região Sudeste a relação especialista/generalista é de 1,38;

- 48,5\% dos médicos possuem 3 vínculos de trabalho ou mais e 29,5\% possuem 2 vínculos;

- 32,4\% trabalham mais que 60 horas semanais e 43,1\% entre 40 e 60 horas;

- 44,6\% trabalham em plantões médicos.

Ou seja, alta concentração na região sudeste, busca por especialização, múltiplos vínculos de trabalho, jornadas semanais extensas e trabalho em regime de plantão e são características importantes dessa população, no Brasil (SHEFFER; BIANCARELLI; CASSENOTE, 2015).

\subsection{A formação médica}

Durante a formação médica nos últimos anos de graduação há um estágio curricular obrigatório de treinamento em serviço, denominado internato médico (PONTES; SOUSAMUÑOZ, 2014). Nele o aluno é imerso em uma formação prática generalista, com aquisição de competências técnicas para a atuação no processo de saúde-doença em seus diferentes níveis de atenção e necessidades, propiciando atuação em promoção, prevenção, recuperação e reabilitação da saúde (ASSOCIAÇÃO BRASILEIRA DE EDUCAÇÃO MÉDICA, 1982; BAFFA, 2008). 
$\mathrm{O}$ internato funciona em regime de rodízio, no qual os estudantes passam em diversos estágios (Clínica Médica, Cirurgia, Ginecologia, Obstetrícia, Pediatria, Saúde Coletiva, Medicina da Família, etc.) e geralmente conta com quatro semestres de duração (dois anos) (FERRI; GOMES, 2015). Apesar de graduandos, a carga de tarefas operacionais e burocráticas em alguns casos pode ser alta, inclusive plantões noturnos, o que pode causar um detrimento do aprendizado (PONTES; SOUSA-MUÑOZ, 2014). Alguns estudantes queixamse de cumprimento excessivo de tarefas operacionais, o que chamam de "tocar serviço" " nas enfermarias (CHAVES; GROSSEMAN, 2007; PONTES; SOUSA-MUÑOZ, 2014).

Após esta fase, o médico formado pode inserir-se em um programa de pós-graduação sob a forma de curso de especialização, mediante aprovação em concurso, chamado de Residência Médica. Segundo o CONSELHO FEDERAL DE MEDICINA (2017) ela funciona em instituições de saúde, sob a orientação de profissionais médicos de elevada qualificação ética e profissional, de acordo com o previsto no decreto 80.281, de 5 de setembro de 1977 , que a regulamenta.

O Programa de Residência Médica, cumprido integralmente dentro de uma determinada especialidade, confere ao médico residente o título de especialista. A expressão "residência médica" só pode ser empregada para programas que sejam credenciados pela Comissão Nacional de Residência Médica (CONSELHO FEDERAL DE MEDICINA, 2017; MINISTÉRIO DA EDUCAÇÃO, 2017), sendo composta pelos Ministérios da Saúde,

\footnotetext{
1 "Tocar serviço" na linguagem médica significa priorizar o atendimento de um grande número de pacientes, atendendo de forma rápida, por vezes sem a supervisão ou cuidado adequado para o caso.
} 
da Educação (MEC) e da Previdência Social (MPAS), além de entidades médicas, como o CFM (CONSELHO FEDERAL DE MEDICINA, 2017).

Em 5 de setembro de 1977 o Decreto no 80.281 (BRASIL, 1977) institui a Residência Médica no Brasil e cria a Comissão Nacional de Residência Médica que tem por finalidade orientar normas em âmbito nacional para o bom funcionamento destes programas. A legislação que rege estes pode ser acessada pelo portal do Ministério da Educação na página "Portarias sobre a Residência Médica” (MINISTÉRIO DA EDUCAÇÃO, 2017b).

Dados sobre a quantidade total de vagas de residência médica no Brasil são de difícil mensuração, pois não há dados oficiais. CHAVES et al. (2013) levantaram os editais para estes concursos no ano de 2011, das instituições cadastradas e atualizadas junto à Comissão Nacional de Saúde, sendo abordadas 362 instituições, estimando aproximadamente 7.931 vagas por ano.

Em 2017 haviam 35.187 médicos cursando residência, em 6.574 programas de 790 instituições credenciadas pela Comissão Nacional de Residência Médica, sendo que 40\% destas vagas estão concentradas em 4 áreas (Clínica Médica, Pediatria, Cirurgia Geral e Ginecologia e Obstetrícia) e 34,5\% dos médicos residentes encontram-se em São Paulo (SHEFFER et al, 2018).

Os profissionais que buscam este meio de especialização almejam um amadurecimento profissional, processo complexo que envolve aquisição de competências resultante da interação de um conjunto de fatores individuais e ambientais (NOGUEIRA-MARTINS, 2010). Este processo se desenvolve durante todo o curso de graduação e tende a se consolidar durante a residência médica, fase caracterizada por um período de plena imersão na atividade profissional, com muitas horas de trabalho e estudo, cuidando-se de pacientes em situações 
assistenciais complexas e, com frequência, de difícil manejo, seja pela gravidade dos quadros clínicos quanto pelas carências e limitações institucionais (NOGUEIRA-MARTINS, 2010).

\subsection{Contextualização dos programas de Residência Médica}

Desde a segunda metade do século 20 houve mudanças científico-tecnológicas de impacto mundial, acompanhadas de contradições ideológicas, filosóficas e éticas que transformaram a área da saúde (BERNARD, 1998). Segundo este autor o desenvolvimento científico aplicado, sustentado pelas tecnologias de informática e automação, aumentou a eficácia dos procedimentos diagnósticos e terapêuticos.

A necessidade de treinamento e capacitação dos profissionais para o uso destas tecnologias levou, no ensino médico, ao modelo das residências médicas e a lógica da formação em serviço. Este movimento resultou no aumento da formação de especialistas e na lógica do cuidado da saúde centrado em hospitais de ensino, sendo que a gestão políticoadministrativa das instituições de saúde orientou-se, no geral, nesta direção (AMORETTI, 2005).

Houve expansão do número de professores e alunos que atuam na formação em medicina, decorrente do crescimento acentuado do aparelho formador em medicina nas três últimas décadas, sobretudo na América Latina e em particular no Brasil (ALMEIDA, 1998).

Segundo AMORETTI (2005), a organização e a expansão dos serviços nos hospitais ocorreram em conjunto com as necessidades de diagnósticos e tratamentos possibilitados pelos recursos então disponíveis. A busca de expansão dos serviços hospitalares orientou o crescimento de vagas nas diferentes residências médicas das especialidades. 
A produtividade apoiada em procedimentos resultou na ampliação da oferta dos serviços, com o consequente aumento dos recursos (humanos, materiais e financeiros). A residência médica, focada no treinamento em serviço, passou a representar mão-de-obra especializada, tornando-se necessária à continuidade da assistência hospitalar (AMORETTI, 2005).

A expansão da residência médica passa então a ocorrer pela necessidade de organização dos próprios serviços médicos para as práticas hospitalares em determinados contextos específicos, e não pelas necessidades sociais de incremento da formação de profissionais de determinada especialidade (AMORETTI, 2005).

Esta mão-de-obra especializada adicional fornecida pela residência é temporária e precisa ser regularmente renovada. Os serviços especializados funcionam adequadamente segundo a sua própria lógica, mas lançam no mercado de trabalho um número crescente de especialistas. A definição das vagas nos programas das residências médicas ocorre, na maior parte das vezes, de forma autônoma e quase automática, segundo as próprias necessidades do serviço, desejo das sociedades de especialistas ou do governo (AMORETTI, 2005).

\subsection{Carga de atividades nos programas de residência}

O Brasil segue o mesmo modelo de residência médica de vários países, como Inglaterra, Suécia, França e Estados Unidos, com duração, a depender da especialidade, de 2 a 5 anos. A diferença de formação nestes casos acontece antes desta fase, durante a graduação e na prestação de serviço obrigatório antes do período da residência em alguns casos (COUSINS, 1981; MCCALL, 1988; NOGUEIRA-MARTINS, 2010; OSWALD; EICHENBERG, 2013; VEASEY et al., 2002). 
Uma longa jornada com horas estendidas é descrita como uma tradição na maioria dos programas em vários países (VEASEY et al., 2002). No Brasil, a Lei 6932 de 1981 estabelece um teto de 60 horas de trabalho semanais, com no mínimo um dia de descanso por semana (preferencialmente aos finais de semana), sendo permitido 24 horas de plantão por semana (BRASIL, 1981). Apesar de não recomendável, uma vez que o vínculo com o hospital é educacional, é permitido ao médico residente trabalhar em outras instituições no seu tempo livre (MOTA et al., 2013).

Segundo GASPAR et al. (1984) os médicos que trabalham em plantões noturnos e frequentemente fazem jornadas superiores a 30 horas, especialmente nos dias em que acumulam um plantão noturno intercalado entre dois períodos diurnos de trabalho, necessitam de atenção especial devido consequências negativas deste ritmo de trabalho.

Em estudo conduzido por MOTA et al. (2013) foram avaliados médicos residentes do Hospital Federal de Uberlândia (Brasil) sobre aspectos metabólicos e dietéticos. 62,5\% dos participantes relataram trabalhar em outros lugares em conjunto com a residência médica, locando este trabalho em períodos noturnos e/ou nos finais de semana.

Em estudo realizado com médicos residentes do Paraná (ASAIAG et al., 2010) a mediana de horas semanais em atividades da residências foram de 66 horas, não considerando os estágios e plantões extra curriculares. Ao levantar a carga horária total, pode-se chegar à 75,9 horas semanais. Tal carga horária de trabalho pode acarretar danos à saúde dos médicos residentes (FABICHAK; DA SILVA-JUNIOR; MORRONE, 2014; LOURENÇÃO; SOLER; MOSCARDINI, 2010; NOGUEIRA-MARTINS，2010; NOGUEIRA-MARTINS; JORGE, 1998). 
Há críticas com relação à sobrecarga de trabalho assistencial, carga horária de trabalho excessiva e privação de sono durante a residência, embora seja reconhecida como uma forma eficiente de capacitação profissional (NOGUEIRA-MARTINS; JORGE, 1998).

A Resolução da Comissão Nacional de Residência Médica $n^{\circ} 4$ de 2011 estabelece a obrigatoriedade de 6 horas consecutivas de descanso imediatamente após o cumprimento do plantão noturno com duração mínima de 12 horas, não sendo permitido o acúmulo de horas de descanso (COMISSÃO NACIONAL DE RESIDÊNCIA MÉDICA, 2011).

As atividades desempenhadas durante a Residência Médica podem ser consideradas como um trabalho em turnos atípico pois os residentes, algumas vezes, trabalham em sucessivos turnos. Após trabalhar no turno noturno, por exemplo, um médico pode ter um dia completo de trabalho (MOTA et al., 2013).

RODRIGUES (1998) discute que o trabalho em turnos é de estudo complexo por lidar com variáveis de difícil mensuração, abranger muitas variáveis que afetam os trabalhadores fora do local de trabalho e tratar de assuntos subjetivos e de caráter multidisciplinar.

Este tipo de trabalho gera quatro fontes principais de dificuldades: a dessincronização dos ritmos biológicos em função das inversões dos períodos de atividade e repouso, as perturbações do ciclo sono-vigília, a necessidade de adequação dos fatores domésticos e a reestruturação das atividades sociais (MONK, 1989).

As funções fisiológicas de um organismo, como temperatura corporal, sono e vigília apresentam ritmicidade própria determinada por osciladores endógenos. A interação entre esses osciladores e sincronizadores ambientais (alternância dia/noite, por exemplo) e sociais (horário de trabalho, por exemplo) resultam na ritmicidade biológica (FISCHER, MORENO, ROTENBERG, 2013). 
Segundo MORENO; FISCHER; ROTENBERG (2003) trabalhar em horários noturnos pode levar à conflitos destes sincronizadores, podendo ocasionar um pior desempenho nas tarefas, aumentar o risco de acidentes de trabalho e expor os trabalhadores de forma mais acentuada a estressores ambientais que podem levar a um envelhecimento funcional precoce.

A restrição de sono, inclusive, afeta negativamente as interações sociais e as decisões comportamentais dos indivíduos, podendo prejudicar na qualidade das interações sociais (DICKINSON; MCELROY, 2017). Podem reduzir as capacidades de regulação emocional e levar a perda de sensibilidade para estímulos que fornecem informações emocionais críticas do ambiente (GOLDSTEIN-PIEKARSKI et al., 2015; SIMON et al., 2015). Estas alterações interferem em vários aspectos da vida cotidiana dos indivíduos (trabalho, estudo, lazer, relacionamentos amorosos, etc.).

CHAGAS CARDOSO et al. (2009) avaliaram a qualidade do sono de estudantes de medicina e médicos residentes da Faculdade de Medicina da Universidade Federal de Goiás. A média de sono desta população é de 6,13 h por noite, inferior à média da população adulta em geral (entre 7 e 9 horas). Segundo este mesmo autor, em conformidade com o encontrado no estudo de PURIM et al. (2016), esta privação de sono pode explicar os períodos de sonolência excessiva, a fragmentação do sono e a pior qualidade subjetiva do sono, características mais marcantes no grupo dos residentes.

Há também efeitos adversos do trabalho em turno para a saúde e bem-estar, inclusive, de médicos residentes. Dentre esses efeitos temos práticas alimentares inapropriadas, sobrepeso, alterações metabólicas, distúrbios do humor, fadiga, desencadeamento ou agravamento de problemas cardiovasculares ou intestinais (MANSUKHANI et al., 2012; MOTA et al., 2013; 
PIKOVSKY et al., 2013; PORTELA; ROTENBERG; WAISSMANN, 2004; VEASEY et al., 2002).

\subsection{Cotidiano e gestão do tempo}

Percebe-se que o trabalho não só é um dos princípios hierárquicos pelo qual a vida social se organiza, como ocupa a maior parte da vida dos indivíduos (MELLO, 1994), compondo grande parte do cotidiano dos médicos residentes.

É necessária a gestão do tempo entre os diversos papéis que desempenhamos no cotidiano que, segundo MAHER (1981), pode ser entendida como a habilidade para planejar quais atividades devem ser realizadas, como cumpri-las e quando fazê-las. Esse planejamento envolve o estabelecimento de prioridades e, a partir delas, as estratégias para alcançá-las (DE SOUSA PELLEGRINI; CALAIS; SALGADO, 2012).

A partir dos anos 60 , com o aumento do número de mulheres no mercado de trabalho, as relações entre as atividades familiares e profissionais entram em foco (EDWARDS, 2001). Alguns estudos desta época designados por "estudos sobre famílias de duplo-emprego ou dupla-carreira" tinham como temática central a análise do conflito entre o trabalho e a vida pessoal (ANDRADE, 2011).

O modelo de EDWARDS; ROTHBARD (2000) descreve a existência de três tipologias de conflitos no desempenho dos papéis no cotidiano:

- de tempo, que surge quando os sujeitos não dispõem do tempo que consideram suficiente para o cumprimento satisfatório das obrigações associadas a cada um dos papéis de vida;

- da pressão associada ao exercício concomitante de papéis, que ocorre quando a insatisfação no exercício de um papel dificulta a resposta às exigências do outro papel; 
- comportamental, que surge quando os comportamentos aprendidos e mesmo reforçados no exercício de um dos papéis não são válidos para o desempenho de outros papéis.

Tanto as exigências de cada um dos papéis, como as características do próprio indivíduo são variáveis que contribuem para o aumento da conflitualidade entre estas representações (FRONE, 2000; MUNIR et al., 2012).

Estes conflitos podem gerar consequências em três níveis:

- do indivíduo: desenvolvimento de depressão, baixa autoestima, má saúde física e consumo de substância aditivas;

- da dinâmica familiar: insatisfação geral com a família e com a relação conjugal, fraca participação nas atividades familiares, ausência em momentos importantes da vida familiar e dificuldades de interação com os filhos;

- no domínio profissional: menor satisfação com o trabalho, menor compromisso organizacional, fraco desempenho profissional e redução da produtividade, absenteísmo (CROUTER et al., 1999; FRONE, 2000; FRONE; MARKEL; YARDLEY, 1997; MUNIR et al., 2012).

Segundo LEMKE et al. (2001) profissionais muito envolvidos em sua carreira podem tolerar a interferência desta em sua vida pessoal ao considerar que este é o preço a pagar por uma profissão que lhes traz recompensas sociais e remuneratórias.

Estas influências nas representações do eu no cotidiano trazem à tona discussões sobre estratégias para conciliação do tempo despendido com atividades profissionais e pessoais (DAVIES, 2014; SANBORN, 2013). O alcance deste equilíbrio não é uma tarefa fácil, por vezes impossível, tendo em vista que os seres humanos apresentam opiniões, condutas e interesses diferentes (ALTOÉ et al., 2014). 
Diversos fatores contribuem para as interferências entre a rotina de trabalho e a familiar, tais como a jornada de trabalho, distância do trajeto para o trabalho, carga horária, falta de apoio gerencial, envolvimento com o trabalho, importância atribuída ao local de trabalho, questões relacionadas ao estado civil, número de filhos e apoio familiar (LEWANDOWSKI, 2012).

CLARK (2000) define que a conciliação entre a vida profissional e pessoal compreende a satisfação e o bom funcionamento nas duas esferas com um mínimo conflito de papéis. Aspectos como atenção, necessidade de horas de trabalho flexíveis, aprendizagem ao longo da vida e preferências individuais podem se refletir nos arranjos laborais e consequentemente nos aspectos inerentes a esta gestão de tempo (KHALLASH; KRUSE, 2012).

As estratégias para conciliar estas tarefas no cotidiano devem propiciar aos indivíduos tanto um conforto relativo ao trabalho quanto às questões pessoais. As práticas mais comuns no ambiente laboral são direcionadas à organização do trabalho e refletem-se na flexibilidade do trabalho, políticas favoráveis à família, concessão de auxílio creche e redução da carga horária (ANDRADE, 2011; DARCY et al., 2012).

Assim, percebe-se a importância de entender as estratégias de gestão do tempo no cotidiano dos médicos residentes, inclusive com as repercussões que o trabalho noturno (plantões) traz para estes. 


\section{HIPÓTESES}

Para este estudo algumas hipóteses foram formuladas:

1) A atual organização da Residência Médica, na especialidade estudada, permite a conciliação entre vida pessoal e profissional;

2) Há vínculos de trabalho dos médicos residentes externos a residência e estes podem afetar de maneira negativa sua vida pessoal;

3) Os plantões noturnos (previstos durante a residência e os realizados em outros vínculos de trabalho) são complicadores da gestão do tempo dos médicos residentes. 


\section{OBJETIVOS}

\subsection{GERAL}

Descrever e analisar as estratégias de gestão do tempo no cotidiano de médicos residentes de Clínica Médica em um hospital público universitário de São Paulo, Brasil.

\subsection{ESPECÍFICOS}

a) Descrever a rotina de médicos residentes de Clínica Médica;

b) Identificar se são realizadas atividades remuneradas não vinculadas à residência médica e, caso haja, sua interferência nas outras atividades do cotidiano;

c) Identificar fatores sociofamiliares dos médicos residentes relacionando-os às estratégias de gestão de tempo;

d) Comparar residentes quando estes realizam plantões noturnos com períodos em que não o fazem, durante dias de trabalho e de folga, em diferentes estágios, quanto a:

- percepção de qualidade do sono;

- duração e alocação do ciclo vigília-sono;

- tempo despendido com família e lazer e a percepção do aproveitamento deste;

- tempo despendido com atividades práticas da residência, estudo e outros trabalhos remunerados. 


\section{MÉTODOS}

\subsection{DESENHO DO ESTUDO}

Este estudo apresenta um desenho misto (quali e quantitativo), em duas fases. TURATO (2005) refere que a pesquisa qualitativa tem como foco a significação atribuída por um indivíduo ou por um grupo de indivíduos a um fenômeno por eles vivenciado, a fim de criar um modelo de entendimento entre as ligações de diversos elementos mostrando uma ordem invisível ao olhar comum.

Desta maneira, na primeira fase do estudo foi realizada entrevista com oito médicos residentes de Clínica Médica, que estavam iniciando o $2^{\circ}$ ano de residência, de diferentes grupos, que descreveram como foram suas atividades durante o $1^{\circ}$ ano de residência médica e como estas interferiram em sua vida pessoal, sendo esta fase de abordagem qualitativa.

Após análise das entrevistas da primeira fase do estudo foram selecionados dois estágios do segundo ano de residência onde foi planejada a avaliação actimétrica, protocolo de atividades diárias e nova entrevista com os participantes, com foco nestes dois estágios, sendo esta fase mista (quanti e qualitativa).

$\mathrm{Na}$ abordagem quantitativa, uma vez que houve o seguimento das atividades dos médicos residentes por 10 dias, embora seja um período curto, considerou-se este um estudo longitudinal (UENO; NATAL, 2013).

\subsection{POPULAÇÃO}

O hospital selecionado é um hospital público, universitário, de grande porte, localizado em São Paulo, Brasil. Segundo os dados do Edital para concurso de Residência Médica 
(COREME, 2016) deste hospital, amparado pelas resoluções do Conselho Nacional de Residência Médica, são definidas como áreas básicas para Residência Médica as seguintes: Cirurgia Geral, Clínica Médica, Medicina da Família e Comunidade, Medicina Preventiva e Social, Obstetrícia e Ginecologia e Pediatria, com 133 vagas, distribuídas conforme a tabela 1. Para o concurso de 2017, para áreas básicas houve 1.663 candidatos para 133 vagas.

Tabela 1- Programas oferecidos em áreas básicas, duração total do programa, número de vagas e de candidatos no concurso para ingresso em 2017, São Paulo, Brasil.

\begin{tabular}{lccc}
\hline Programa & Duração (anos) & Vagas & Candidatos \\
\hline Áreas básicas & 2 & 31 & 442 \\
Cirurgia Geral & 2 & 40 & 666 \\
Clínica Médica & 2 & 7 & 36 \\
Medicina de Família e Comunidade & 2 & 6 & 14 \\
Medicina Preventiva e Social & 3 & 14 & 184 \\
Obstetrícia e Ginecologia & 3 & 35 & 321 \\
Pediatria & & $\mathbf{1 3 3}$ & $\mathbf{1 6 6 3}$ \\
Total & & & \\
\hline Fonte: Informações extraídas de COREME (2016).
\end{tabular}

Fonte: Informações extraídas de COREME (2016).

Há 60 vagas anuais para a Residência de Clínica Médica, porém, neste concurso, 20 vagas estavam asseguradas para candidatos aprovados no concurso anterior e que participaram do Serviço Militar Obrigatório

Para viabilidade do estudo escolheu-se a Clínica Médica como população alvo por três principais motivos:

a) tratar-se da área básica com a maior quantidade de residentes (60 por ano); 
b) por ser uma área básica intermediária para várias especialidades, como por exemplo cardiologia, pneumologia, endocrinologia, geriatria, entre outras;

c) ser uma área clínica com plantões noturnos previstos durante alguns estágios da residência.

A Clínica Médica, também conhecida como Medicina Interna treina especialistas que aplicam o conhecimento científico e experiência clínica para o diagnóstico, prevenção, tratamento e cuidados do paciente adulto, envolvendo todo o espectro da saúde, até mesmo as doenças complexas (NUNES; SANTANA, 2016).

Os residentes de Clínica Médica, no hospital estudado, são divididos em grupos de 5 a 6 componentes e cada grupo permanece 1 mês em cada estágio, incluindo as férias.

\subsection{CRITÉRIO DE INCLUSÃO}

$\mathrm{O}$ critério de inclusão neste estudo foi cursar o $2^{\circ}$ ano do programa de residência no hospital escolhido, pois estes já sofreram a exposição que desejamos estudar. Os médicos residentes do $1^{\circ}$ ano iniciaram suas atividades há pouco tempo, na ocasião do estudo, não sendo adequado sua escolha para esta pesquisa.

\subsection{AMOSTRA DO ESTUDO}

A amostra selecionada para este estudo foi de 12 residentes, sendo que 8 participaram da primeira fase e 7 participaram na segunda fase (alguns residentes participaram das duas fases). Na segunda fase cinco estavam no estágio de Avaliação Pré-Operatória e 2 no estágio do Pronto-Socorro de Clínica Médica, como observaremos na Figura 1, adiante. 


\subsection{COLETA DE DADOS}

Após abordagem presencial do primeiro residente, outros residentes foram sendo indicados por este. Realizado contato telefônico com os outros convidados e agendado entrevistas fora do horário de trabalho / residência, em localidades próximas ao hospital estudado, como bibliotecas, cafés ou mesmo na faculdade.

$\mathrm{Na}$ primeira fase do estudo foram convidados a participar 14 residentes, no início do $2^{\circ}$ ano de residência de Clínica Médica, de diversas "panelas"" ou grupos de reisdência. Destes, 8 aceitaram participar do estudo.

Após as entrevistas da $1^{\circ}$ fase, foram selecionadas as categorias que comporiam o protocolo de atividade diária: atividades da residência (aquelas praticadas no horário previsto a residência médica), trabalho (entendido como atividades remuneradas não relacionadas a residência médica), estudo (realizado fora do horário previsto para as atividades da residência), sono, lazer, transporte, alimentação ou outras atividades.

Foram selecionados os estágios que participariam da $2^{\circ}$ fase do estudo: o Ambulatório de Avaliação Pré-Operatória (Pré-op) foi escolhido por ser referido pelos residentes como o estágio com menor carga horária de atividade prática e de menor complexidade e, como seu contraponto, o estágio no Pronto-Socorro de Clínica Médica (PSM).

Aceitaram participar da $2^{\circ}$ fase da pesquisa 5 residentes que estavam no estágio Pré-op e 2 residentes que estavam no PSM. Foi aplicado questionário sociodemográfico e coletados dados de actimetria em conjunto com protocolos de atividades diárias. Esta fase teve duração de 10 dias consecutivos, que incluam dias de folga e de trabalho e foi realizada, como

\footnotetext{
2 "Panelas" na linguagem dos residentes são os grupos definidos no início da residência para realizar os estágios. No caso, cada "Panela" de residentes de Clínica Médica é composta por 5 ou 6 residentes.
} 
tentativa de comparação, no estágio de maior e menor complexidade do segundo ano de residência, em grupos diferentes, em agosto de 2017.

Devido a repetidas falhas de equipamento e de uso dos actímetros estes resultados foram excluídos do estudo, sendo mantido apenas os dados obtidos pelos protocolos de atividades diárias.

Após análise destes resultados, foram realizadas novas entrevistas com os participantes da $2^{\circ}$ fase, para validação dos dados quantitativos e aprofundamento do entendimento destes estágios. Na Figura 1 segue organograma da coleta de dados.

Figura 1- Organograma da coleta de dados, São Paulo, Brasil, 2017.

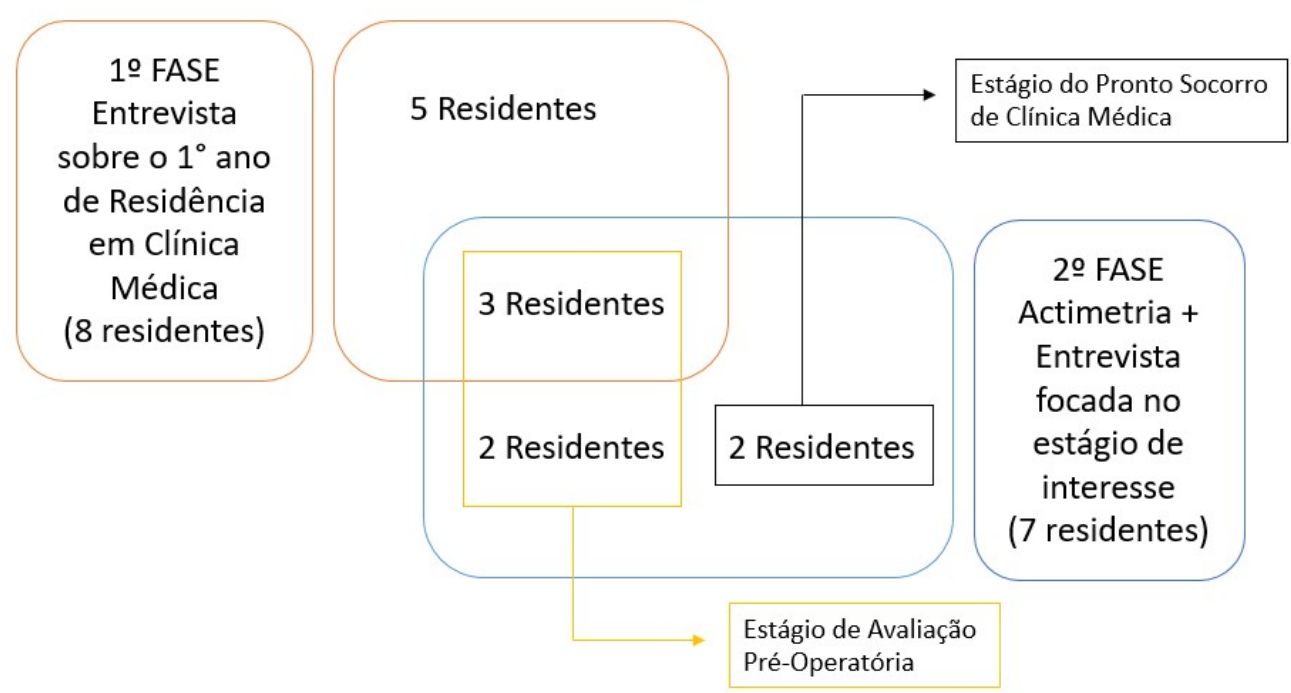

Fonte: Dados da pesquisa. Elaboração própria.

\subsection{INSTRUMENTOS DE CAMPO}

Durante a pesquisa de campo foram utilizados os seguintes instrumentos de campo: entrevista semiestruturada e protocolo de atividades diárias. 


\subsubsection{Entrevista semiestruturada}

A entrevista é uma técnica muito utilizada na pesquisa qualitativa, tanto por seu caráter econômico quanto por possibilitar a exploração de um longo material empírico. Optou-se pelo método de entrevista compreensiva, o qual é composto por um processo circular entre compreensão, escuta atenta, recuo do pesquisador e análise crítica, uma técnica mais pessoal do que rígida, decorrente do envolvimento do investigador no desenvolvimento da pesquisa mas mantendo grau de formalização mais elevado que as técnicas etnográficas (FERREIRA, 2014).

Realizou-se entrevistas semiestruturadas com os médicos residentes, a fim de analisar as estratégias de gestão do tempo do cotidiano destes trabalhadores na primeira fase deste estudo, cujas questões norteadoras foram formuladas com base nos estudos de ALTOÉ et al. (2014) e WONG; KO (2009).

O roteiro utilizado para direcionamento das entrevistas encontra-se no ANEXO IV. Este instrumento não foi utilizado de maneira rígida, sendo que os pontos elencados não foram abordados necessariamente nesta ordem, ocorrendo o aprofundamento ou não em cada tópico de acordo com as interações entre entrevistador e entrevistado.

As entrevistas foram gravadas em aparelho gravador digital e posteriormente transcritas.

4.6.2 Protocolo de atividades diárias.

KNAUTH et al. (1983) idealizaram o protocolo de atividades diárias, o qual foi adaptado por FISCHER (1986). Este instrumento consiste em uma grade horária de 24 horas dividida 
em intervalos de tempo de 15 minutos, que pode apresentar várias opções de atividades. Os participantes foram orientados a traçar uma reta do horário de início de cada atividade até o fim da mesma. O modelo de protocolo utilizado neste estudo consta no ANEXO V.

Esse procedimento fornece detalhes sobre as atividades realizadas durante o dia, sendo realizado durante os dias em que o participante estava em uso do actímetro.

MONK (1989) desenvolveu escalas analógicas visuais para avaliação de estados afetivos, as quais foram utilizadas na avaliação da qualidade do sono em diversos estudos (AKERSTEDT; GILLBERG, 1982; BORGES, 2002). A percepção da qualidade do sono foi verificada neste protocolo, que incluiu escalas analógicas visuais de 10 centímetros, que foram precedidas pelas perguntas “Como foi a qualidade de seu sono noturno? E diurno?" e “Como você sentiu-se ao acordar do seu sono noturno? E diurno?”. Os participantes foram orientados a assinalar com um traço vertical a sua percepção quanto à qualidade do sono. A escala inicia com a expressão "muito ruim" (valor zero) e finaliza com "muito bom/muito bem" (valor dez). Após a marcação, o valor foi medido com uma régua para determinar a percepção da qualidade do sono, em até uma casa decimal.

\subsubsection{Pré-teste}

Segundo RICHARDSON (1999) o pré-teste deve ser aplicado em grupos que apresentem as mesmas características da população incluída na pesquisa, sendo importantes para revisar e direcionar aspectos da investigação. Tais testes permitem que o investigador avalie a exatidão e coerência das respostas antes da aplicação em grandes populações.

Os instrumentos de pesquisa foram submetidos a um pré-teste com o intuito de eliminar as possíveis inconsistências e minimizar as dificuldades de compreensão. Para a realização do 
pré-teste, os instrumentos de pesquisa foram aplicados em dois médicos residentes do Hospital Universitário onde o estudo foi conduzido. O grupo piloto foi constituído por conveniência, com médicos residentes do $2^{\circ}$ ano de residência, que não cursavam a área de Clínica Médica. Durante aplicação do pré-teste não houve falhas na utilização ou no equipamento para actimetria. O pré-teste auxiliou no treinamento e adequação das perguntas para as estrevistas da $1^{\circ}$ fase do estudo.

\subsection{ANÁLISE DE DADOS}

Para análise qualitativa utilizou-se a análise de conteúdo, por ser um conjunto de técnicas de comunicação que, por procedimentos sistemáticos obtém indicadores que permitem a inferência de conhecimento relativo à produção / percepção destas mensagens (OLIVEIRA, 2008).

Os dados foram categorizados e analisados com a ajuda do software MaxQDA 12 (Qualitative Data Analysis Software), que auxiliou na organização de arquivos em grupos e na criação de links para relacionar diferentes citações (MAXQDA, 2017).

Para análise dos dados quantitativos foi utilizado o programa Microsoft Excel (MICROSOFT CORPORATION, 2013) encontrando-se média, mediana e desvio padrão, para os valores encontrados. Por tratar-se de um baixo número de participantes, não foi realizada análise estatística entre os grupos, apenas a comparação descritiva destes dados.

\subsection{ASPECTOS ÉTICOS}

Esta pesquisa obteve a anuência da Comissão de Residência Médica do hospital estudado (ANEXO I) e está cadastrada na Plataforma Brasil, com aprovação do Comitê de Ética e 
Pesquisa da Faculdade de Saúde Pública da Universidade de São Paulo (FSP/USP) (ANEXO II), número CAAE 62190916.0.0000.5421.

Os participantes do estudo receberam e aderiram ao termo de consentimento livre e esclarecido (ANEXO III) conforme resolução 466/123 do Conselho Nacional de Ética em Pesquisa (BRASIL, 2012), sendo seguido as recomendações desta resolução.

\footnotetext{
${ }^{3}$ Em vigor na data de aprovação
} 


\section{RESULTADOS}

Doze residentes de Clínica Médica aceitaram participar deste estudo. Apresentam média de idade de 27 anos, sem filhos. Sete participantes (58\%) do sexo masculino e 4 (33\%) em uso de medicações para ansiedade ou depressão. Oito residentes participaram da primeira fase desse estudo e 7 participaram da segunda. Na Tabela 2 segue uma breve caracterização destes participantes, a fase do estudo na qual participaram e, no caso da $2^{\circ}$ fase, em qual estágio estavam.

Tabela 2- Caracterização dos residentes que participaram do estudo, São Paulo, Brasil, 2017.

\begin{tabular}{cccccccc}
\hline $\begin{array}{c}\text { Identificação } \\
\text { do participante }\end{array}$ & Idade & Sexo & $\begin{array}{c}\text { Participou da } \\
\text { primeira fase }\end{array}$ & $\begin{array}{c}\text { Participou da } \\
\text { segunda fase }\end{array}$ & $\begin{array}{c}\text { Estágio da } \\
2^{\circ} \text { fase }\end{array}$ & $\begin{array}{c}\text { Medicações } \\
\text { em uso }\end{array}$ & Filhos? \\
\hline P1 & 27 & Masculino & Sim & Não & -- & Não & Não \\
P2 & 26 & Feminino & Sim & Não & -- & Não & Não \\
P3 & 27 & Feminino & Sim & Não & -- & Alprazolan & Não \\
P4 & 28 & Masculino & Sim & Não & -- & Não & Não \\
P5 & 26 & Feminino & Sim & Não & -- & Não & Não \\
P6 & 27 & Masculino & Sim & Sim & PRÉ-OP & Minoxidil & Não \\
P7 & 28 & Masculino & Sim & Sim & PRÉ-OP & Não & Não \\
P8 & 25 & Feminino & Sim & Sim & PRÉ-OP & Fluoxetina & Não \\
P9 & 27 & Masculino & Não & Sim & PRÉ-OP & Paroxetina & Não \\
P10 & 27 & Feminino & Não & Sim & PRÉ-OP & Levotiroxina & Não \\
P11 & 27 & Masculino & Não & Sim & PSM & Venlafaxina & Não \\
P12 & 26 & Masculino & Não & Sim & PSM & Não & Não \\
\hline
\end{tabular}

Fonte: Dados da pesquisa. Elaboração própria.

Nota: PRÉ-OP: Ambulatório de Avaliação Pré-Operatória; PSM: Pronto-Socorro de Clínica Médica.

Durante as entrevistas os residentes forneceram a grade de estágios previstos nos dois anos de residência. A escala do primeiro ano de Residência, a duração de cada estágio e a presença de plantões noturnos, em fim-de-semana ou em feriados seguem detalhados na Tabela 3 , enquanto a escala para os residentes do $2^{\circ}$ ano seguem na Tabela 4 . Importante salientar que cada grupo segue uma ordem diferente destes estágios e que esta escala pode 
sofrer alterações quanto aos estágios que a compões ou mesmo a duração de cada um deles no início do ano letivo.

Tabela 3- Grade de estágios do primeiro ano de Clínica Médica no Hospital Estudado, São Paulo, Brasil, 2017.

\begin{tabular}{lccc}
\hline Estágio & Sigla & $\begin{array}{c}\text { Duração } \\
\text { (em meses) }\end{array}$ & $\begin{array}{c}\text { Presença de Plantão Noturno e/ou Fim de } \\
\text { Semana/Feriado }\end{array}$ \\
\hline Férias & --- & 1 & --- \\
Ambulatório Geral e Didático de Clínica Médica & AGD & 2 & Enf. HU (fim-de-semana e feriado) \\
Unidade de Terapia Intensiva & UTI & 1 & Na própria UTI \\
Enfermaria de Hospital Secundário & Enf. H & 2 & Enf. HU (noite) \\
Pronto-socorro de Clínica Médica & PSM & 1 & No próprio PSM \\
Unidade de Cuidados Intermediários & UCI & 1 & Na própria UCI \\
Pronto-socorro de Hospital Cardiológico & PSCor & 1 & No próprio PSCor \\
Unidade Coronariana & UCO & 1 & Na própria UCO \\
Estágio Eletivo 1 & --- & 1 & Código Azul (intercorrências em enfermaria) \\
Estágio Eletivo 2 & --- & 1 & Enfermaria de Clínica do $5^{\circ}$ e $6^{\circ}$ andar \\
\hline Fonte: Dados da pesquisa. Elaborañ
\end{tabular}

Fonte: Dados da pesquisa. Elaboração própria.

Tabela 4- Grade de estágios do segundo ano de Clínica Médica no Hospital Estudado, São Paulo, Brasil, 2017.

\begin{tabular}{lccc}
\hline Estágio & Sigla & $\begin{array}{c}\text { Duração } \\
\text { (em meses) }\end{array}$ & $\begin{array}{c}\text { Presença de Plantão Noturno e/ou Fim de } \\
\text { Semana/Feriado }\end{array}$ \\
\hline Férias & --- & 1 & -- \\
InterconsultaPré-operatórioNAD & Pré-op & 1 & IC (diurnos, nos Finais de Semana) \\
Instituto do Câncer & IC & 1 & --- \\
Enfermaria de Clínica Médica (5ªndar) & Enf. 5 & 1 & Na própria Enf. \\
Pronto-socorro de Clínica Médica & PSM & 1 & No próprio PSM \\
Unidade de Terapia Intensiva & UTI & 2 & Na própria UTI \\
Pronto Atendimento de Hosp. Secundário & PA H & 1 & No próprio PA \\
Enfermaria de Clínica Médica (6 $6^{\circ}$ andar) & Enf. $6^{\circ}$ & 2 & Na própria Enf. \\
Estágio Eletivo 1 & --- & 1 & No PSM (noite) \\
Estágio Eletivo 2 & --- & 1 & No PSM (noite) \\
\hline
\end{tabular}

Fonte: Dados da pesquisa. Elaboração própria.

As atividades previstas durante a residência são divididas entre estágios Ambulatoriais (AGD, PRÉ-OP, IC) nos quais são atendidos pacientes com consultas agendadas, estágios de 
Pronto-Socorro (PSM, PSCor, PA H) nos quais são atendidos pacientes com quadros agudos que ameaçam a vida, estágios de Enfermarias (HU, Enf $5^{\circ}$, Enf $6^{\circ}$ ) nos quais são atendidos pacientes que estão internados em situações menos complexas) e estágios de Unidades de Terapia Intensiva ou Intermediárias (UTI, UCI e UCO) nos quais há pacientes internados em situações mais complexas.

A seguir serão descritos os resultados da $1^{\circ}$ e $2^{\circ}$ fase deste estudo.

\subsection{RESULTADOS DA $1^{\circ}$ FASE DO ESTUDO}

Após a análise das oito entrevistas sobre a residência médica em seu primeiro ano 5 categorias foram selecionadas para este estudo, descritas abaixo e agrupadas na Tabela 5.

Tabela 5 - Resumo das categorias selecionadas para este estudo, São Paulo, Brasil, 2017.

\begin{tabular}{ll}
\hline Categorias & Contexto abordado pela categoria \\
\hline $\begin{array}{l}\text { Organização do trabalho durante as } \\
\text { atividades práticas da residência }\end{array}$ & $\begin{array}{l}\text { Explicações sobre como funcionam os diversos estágios da } \\
\text { Residência em Clínica Médica }\end{array}$ \\
$\begin{array}{l}\text { Atividade para aprendizado ou } \\
\text { atividade profissional? }\end{array}$ & $\begin{array}{l}\text { Abordagem da dualidade entre o vínculo para ensino e a } \\
\text { necessidade de atendimento do serviço }\end{array}$ \\
$\begin{array}{l}\text { Moradia, planejamento financeiro e } \\
\text { atividades domésticas }\end{array}$ & $\begin{array}{l}\text { Relatos explicando como se dá a escolha da moradia e sua } \\
\text { manutenção e a interferência do planejamento financeiro }\end{array}$ \\
$\begin{array}{l}\text { Tempo para lazer e relacionamentos } \\
\text { interpessoais }\end{array}$ & $\begin{array}{l}\text { Como o residente lida com o tempo disponível para lazer e } \\
\text { com os relacionamentos interpessoais do cotidiano }\end{array}$ \\
Planejamento familiar/filhos & $\begin{array}{l}\text { Qual o planejamento do residente sobre filhos e quais } \\
\text { questões norteiam estas decisões } \\
\text { Relatos sobre o tempo para repouso/sono e a percepção da } \\
\text { qualidade deste }\end{array}$ \\
\hline Repouso/Sono &
\end{tabular}

Fonte: Dados da pesquisa. Elaboração própria. 


\section{a) Organização do trabalho nas atividades práticas da residência médica}

A residência em clínica médica no hospital estudado é dividida em diversos estágios com duração de 1 a 2 meses cada. Cada estágio apresenta uma gama de atividades previstas. Didaticamente conseguimos dividir esses estágios em estágios com atividades de prontosocorros, de enfermarias, ambulatoriais e de unidades de terapia intensiva ou semi,

"São plantões dentro de um mesmo ambiente [...] pacientes já internados. Se trabalha o dia inteiro, aí você emenda no plantão noturno, então, no geral, a maior parte do estágio a gente acaba fazendo 24 horas na verdade! você já trabalhou o dia inteiro e você só emendou o noturno até o dia seguinte. A gente até aumentava um pouco mais porque tinha que passar visita ${ }^{4}$ depois. Então, em vez de 24 horas ia para 26, 27. Chega um momento a noite que você perde o rendimento, né? A vantagem desses plantões é que geralmente dá para você dormir um pouco porque é um ambiente controlado, então teoricamente, se não está acontecendo nada, você consegue descansar, só que também é dependente do dia, dependente se teve algum problema com os pacientes ou não [...]"

P6, masc

\footnotetext{
4 "Passar visita" na linguagem médica significa a discussão com o grupo de residentes que ocorre caso a caso nas enfermarias, acompanhado do supervisor, geralmente à beira do leito.
} 
Nas falas que descrevem o estágio da UTI percebemos a sobrecarga física dos residentes, devido um estágio com alta carga horária em que, às vezes, é necessário realizar plantões noturnos após atividade diurna. Há a queda de rendimento percebida pelos próprios médicos, acentuada no período noturno além da discussão dos casos em grupo que ocorrem após o plantão.

"Na [Enf. H] a gente entra umas 07:00 h da manhã e aí fica lá o dia inteiro. Evolui os pacientes. Às vezes, na hora do almoço tinha alguma aulinha e depois voltava. A tarde você ia resolver as pendencias do paciente ou fazer internação ou fazer as coisas da alta. Se você for rápido dá para terminar lá pelas 15:00 h. Todo dia alguém de algum grupo ficava até as 17 h00h para resolver as intercorrências [...] e todo dia ficava um de plantão, ai quem ficava de plantão ficava lá a noite inteira, de manhã acordava, evoluía seus pacientes, resolvia as pendencias e ia para casa [...]"

$\mathrm{P} 2$, fem.

As atividades nas Enfermarias ocupam uma carga horária menor em relação à UTI: a maior parte do grupo cessa suas atividades por volta das 15:00hs. Um dos residentes permanece na enfermaria até as 17:00ha e outro fica de plantão durante à noite, sendo liberado após a avaliação dos pacientes em conjunto com os outros residentes e o supervisor na manhã seguinte, chamada de "visita". 
“[...] plantão de PS não dá para descansar [....] nem do PSCor, nem do PSM porque no PSCor você é o único residente a noite lá, entendeu? [...] junto com os internos e os da casa [referindo-se aos residentes do hospital do PSCor] mas para tocar a porta lá você é o único médico, os da casa ficam nas salas de emergência e na retaguarda [....] então você fica responsável por bastante coisa." P5, fem.

As atividades nos Prontos-Socorros são consideradas desgastantes. Nestes plantões são relatados a ausência de descanso e um estado de alerta constante pelo residente.

“Tem os eletivos que é bem tranquilo, geralmente você escolhe onde você quer passar [...] eu passei no eletro, muito tranquilo, muito bom; entrava ás $08 h 00$ da manhã e saía as 15 h00 da tarde e nesses estágios [eletivos] a gente dá plantão a noite no código azul que é para os pacientes que tem alguma emergência do hospital, paciente de enfermaria que de repente começa a passar mal, a enfermagem chama o código azul e a gente vai lá atender"

P2, fem.

Há 2 meses de estágios eletivos durante os quais os residentes escolhem onde desejam estagiar. Na grande maioria são escolhidos estágios ambulatoriais. Durante este período eles realizam, como atividade noturna, plantões de intercorrências nas enfermarias, chamados de “código azul”. 
Percebe-se pelas falas que as Unidades de Terapia Intensiva, Intermediárias e os ProntoSocorros aparecem com uma alta demanda de tempo e complexidade, por vezes relatado como um trabalho desgastante, o que já não acontece nos estágios ambulatoriais, eletivos e de enfermarias.

“[...] por exemplo na UCI, que foi o estágio que traumatizou toda minha panela. É, a gente teve muitos pacientes que acabaram falecendo e tal e são casos assim complicadíssimos [...] pra mim o pior foi quando eu tive que dar uma notícia de morte cerebral para um pai de um paciente de 19 anos, então você vai pegando esses tipos de casos, que acaba mexendo muito com você, e a gente ainda é meio cru, então a gente não aprendeu ter tantos mecanismos de defesas emocionais [...] é uma carga horária alta, mas o pior não era a carga horária, que ai a gente consegue lidar, o pior era o que a gente tinha que conviver dentro da residência, tipo com essas histórias, com esses pacientes."

P6, masc.

Há uma exposição do residente a situações complexas e pacientes graves. Apesar de ser uma etapa importante da formação, a maneira com que estas exposições ocorrem não parecem ser a adequada. Como a maioria dos residentes possuem pouco tempo de formado (graduado) não desenvolveram mecanismos de defesa e estratégias de abordagem suficientes para lidar com essas situações sem apoio adequado da supervisão do programa. 
“[...] o plantão é bem cansativo também. Eu já passei situação assim [durante estágio na UCI] de estar escrevendo [...] e dar uma piscada no meio da evolução [...] uma vez fui escrever para medicação: glicose, para glicemia, eu fui escrever 4 ampolas [...] cada ampola 10 ml, $40 \mathrm{ml}$ de glicose. Só que coloquei 40 ampolas por causa do sono, assim, eu pisquei."

P1, masc.

“[...] eu gosto de escutar o paciente, por mais bobas que as queixas sejam, [...] no final do plantão, a paciência vai se esgotando, então essas queixas bobas você já não trata da mesma forma como se deve tratar [...] casos mais graves .... coisas que se eu não tivesse cansado, não passaria, passam despercebido, com grande facilidade”

P4, masc.

"[...] às vezes há o momento de não conseguir mais pensar, de não conseguir raciocinar, fazer algo automático! às vezes dar uma dose errada de medicamento e ser chamado pela enfermagem: -Doutor isso aqui está errado!... por causa do sono. Geralmente os plantões noturnos são 24 horas, porque você está de dia na residência e tem o plantão á noite, nunca é só a noite então acaba que é aquela coisa que se estende e, volta e meia, o desempenho acaba prejudicado [...]" P7, masc. 
O tempo de atividade na jornada é comumente apontado como um fator estressante e cansativo que propicia posturas profissionais por vezes não adequadas ou mesmo equívocos de prescrição. Há uma clara percepção de piora na qualidade do atendimento quanto maior o tempo na jornada de trabalho. O cansaço aparece como fator crucial impactando nas decisões médicas e na relação médico paciente.

Os próprios residentes sabem que seu rendimento está abaixo do esperado, mas há a necessidade de desempenho das atividades, principalmente durante a realização de plantões noturnos após as atividades diurnas.

“É relativamente comum [entrevistado que trabalhou 6 noites seguidas no pronto-socorro] [...] a gente tem 30 dias e 21 plantões pra dar, e a gente não trabalha 24hs, o que eu acho bom porque eu não conseguiria também [...] se eu faço 5 plantões seguidos eu estou acabado, então tipo, eu vou perder o sexto dia ali, ter aquele dia livre mesmo não vai adiantar, às vezes o que a gente faz é juntar, fazer vários plantões, pra livrar mais, ou antes ou depois [...] em duas semanas eu faço 12 plantões, então em outras duas semanas eu só tenho 8, aí eu consigo vários dias livres depois [...] o controle que eles fazem é mensal, eles não fazem controle na semana, porque quem define essas escalas somos nós, então eles colocam um número de plantões a partir das 60hs semanais, só que quem vai definir o quanto a gente vai fazer somos nós."

P6, masc. 
Diversos estágios preconizam atividades de plantões. Nos estágios de prontos-socorros a escala inteira é dividida em plantões de 12 horas, que são distribuídos pelos próprios residentes de forma equitativa. As horas totais são controladas mas como a distribuição destes plantões fica a cargo dos próprios residentes, em alguns casos, há períodos com vários dias de atividades contínuas para maximizar possíveis folgas.

“[...] existe [referindo-se as folgas pós-plantão], ela não é tão caxias na enfermaria porque você evolui ainda o paciente no dia, plantão inicia as 19:00h acaba as 07:00h, mais você vai embora 10, 11:00h, mas ai também não precisa voltar [...] já no PS é das 19 horas da noite as 7 horas da manhã e acabou, pelo menos isso, PS eu não dormia nada, nada, nada [...]"

$\mathrm{P} 4$, masc.

A folga pós plantão, determinada pela Resolução CNRM n 4 de 2011 (COMISSÃO NACIONAL DE RESIDÊNCIA MÉDICA, 2011) é respeitada, porém, em alguns estágios a jornada noturna é estendida, ultrapassando as habituais 12 horas de plantão devido às “evoluções $5 "$ e "visitas"

\footnotetext{
${ }^{5}$ Evoluir na linguagem médica significa avaliar o paciente, registrar o atendimento no prontuário e realizar a prescrição médica.

6 "Passar visita" na linguagem médica significa a discussão com o grupo de residentes que ocorre caso a caso nas enfermarias, acompanhado do supervisor, geralmente à beira do leito.
} 
"No pronto-socorro você faz a carga horaria certinha: 60 horas, ai é independentemente se era noturno ou diurno, variava muito por semana: tem semana que a gente fazia uns direto, tipo 3 noites seguidas, ai depois voltava para a parte do dia [...] era ruim [...] as duas primeiras noites são muitos ruins, porque você está todo bagunçado. Na terceira em diante você se acostuma e seu horário biológico meio que vira aí você consegue dormir, chegava em casa as 10:00h da manhã, dormia até umas 17:00h da tarde acordava, comia e ia de novo para o plantão [...] quando você se adaptava esse novo horário tem que voltar a rotina de trabalhar de dia"

$\mathrm{P} 1$, masc.

"Os dois estágios que eu dei de cara foi a UTI e o Pronto-Socorro e teve essa questão: não pregava o olho a noite inteira e ficava tenso a noite inteira. Então, e aí o ruim era esse: chegava em casa e seu sono é muito ruim, durante o dia eu não recuperava [...] chegava em casa dormia, 4 horas, acordava e não conseguia mais dormir, ficava um cansado e tals, não recuperava, depois de uns dois dias que você fala: agora eu estou recuperado"

$$
\text { P1, masc. }
$$

A tolerância para trabalho em turno também é colocada como ponto chave pelos residentes, principalmente com os trabalhos em dias seguidos. As mudanças de horários 
constantes, em alguns estágios, alternando plantões noturnos e diurnos é apontado como um fator de complicação para as atividades sociais e para o repouso adequado.

“[...] depois do plantão [...] você tem a folga e você não dorme naquela folga [...] aproveita a folga por que na folga é de dia que as lojas estão abertas, dá para levar o cachorro para tomar banho [...] então, tem que aproveitar esse momento ... de dia não dá para descansar tanto"

P3, fem.

“[...] no dia seguinte você tem pós plantão então dava pra emendar com os plantões fora [...]"

P5, fem.

Devido ao pouco tempo livre em alguns estágios, muitas vezes, o tempo que seria destinado para descanso acaba sendo ocupado com outras atividades do cotidiano ou mesmo com outras atividades remuneradas.

\section{b) Atividade para aprendizado ou atividade profissional?}

Muitos hospitais e serviços de saúde utilizam-se das atividades práticas dos residentes como pilar fundamental para manter o atendimento. 
“[...] a parte do dinheiro impactou bastante [...] você vai lá fora e vê que você consegue ganhar bem, e na residência você perde toda sua disponibilidade pra trabalhar, então você tem que fazer uma readequação grande e é muito fácil na hora que você está parado se perder nos gastos [...] eu ganho, sei lá, atualmente 1/4 do que eu ganhava, 1/3 talvez [...] agora, a parte da carga horária que é a grande questão [...] fora que muitos pontos você se sente trabalhando num lugar que você não tem a assistência que você esperava, você se sente trabalhando mesmo pra tocar serviço, você sabe que você não está ganhando, sabe tipo, você ganha muito pouco pela hora, então tem seus momentos de frustração [...]"

P6, masc.

O limite entre as atividades para aprendizado e as atividades para manter o serviço em funcionamento são muito tênues, e a vantagem de manter estes médicos é clara, uma vez que que a bolsa de residência é aproximadamente $1 / 7$ do valor que estes profissionais ganhariam se fossem contratados em regime CLT pelos serviços.

“E eu, como estudei muito no $6^{\circ}$ ano para prestar a prova [referindose a prova de ingresso na residência] estava então um pouco de saco cheio assim sabe... daquele estudo que você senta um pouco por dia ... eu não fiz isso ao longo deste ano inteiro. Eu peguei a primeira vez num livro para sentar e estudar em fevereiro desse ano, depois de 
novembro de 2015 [risos] entendeu? Então ... era falta de tempo junto com outras coisas para conciliar e foi uma opção minha, foi consciente, mas não deixava de me deixar aflita, entendeu?"

P5, fem.

Poucos estágios preconizam tempo para estudo teórico. Há unanimidade nos relatos que seriam necessárias mais horas de estudo teórico durante o curso, no entanto o mesmo não ocorre devido à baixa disponibilidade de tempo para o mesmo.

“A assistente do meu grupo era super brava, ela puxava a orelha nas coisas certas, por exemplo. Não certas mas, é... ela prestava atenção na gente. Por exemplo, eu ia toda descabelada, ele via que eu estava toda descabelada e falava: Ah, você está descabelada [risos]”

$$
\text { P3, fem. }
$$

“O povo nessa fase só pensa na parte profissional então tudo que pode atrapalhar isso te deixa com certo receio. As vezes podem te olhar de um outro jeito, diferente. Estão esperando só a parte de trabalhar e render e tal. Qualquer situação diferente pode atrapalhar o serviço... então a gente tipo, tinha um pouco de receio em relação a isso."

P1, masc. 
Por tratar-se de atividades vinculadas à ensino - aprendizagem há preocupação dos residentes pela avaliação dos supervisores, que ocorre diariamente e envolve diversas esferas, desde a aquisição de conhecimento quanto a postura durante o desempenho das tarefas. Percebe-se uma preocupação também com a opinião dos pares (outros médicos residentes) sobre o desempenho pessoal.

Como forma de apoio ao médico residente, a residência em clínica médica possui um programa de tutoria estruturado, onde cada médico tutor orienta um grupo de 8 residentes, com reuniões mensais, a fim de verificar sua adaptação a residência, auxiliar no andamento do curso ou mesmo em questões pessoais.

“[...] é uma tutoria que é uma vez por mês, em que a gente se reúne para debater questões mais éticas, de trabalho e tudo mais, mas acaba sendo um ambiente que a gente usa para conversar sobre coisas que aconteceram; eles até pedem para gente fazer o que chamam de incidente crítico, escrever coisas que foram muito ruins ou muito boas que marcaram a gente e a gente discute a respeito dos casos [...] interessante, legal [...] tipo, se a pessoa precisa de um suporte psicológico maior, não é só isso que vai resolver, mas consegue abrir uma porta para a pessoa, para ele conversar [...]"

P6, masc.

“[...] gosto muito dela [referindo-se a sua tutora], e ela percebeu minha mudança dos 2 meses do HU pra UTI do PS [...] ela acabou perguntando mais, e eu acabei falando do convívio que eu tinha muito 
ruim com uma $R 3$ [...] ela falava de uma forma desrespeitosa com todos nós [...] a partir disso me pediu autorização, fez uma queixa formal da clínica medica, de assédio moral, acabei nem vendo o desfecho, nem me interessei... passou."

$$
\text { P4, masc. }
$$

Os residentes relatam esta iniciativa de forma positiva, demonstrando uma aproximação da instituição / professores com o aluno e gerando oportunidades para troca de experiências e diálogo entre os próprios estudantes e com os professores do programa.

\section{c) Moradia, planejamento financeiro e atividades domésticas}

Em sua totalidade os residentes moram próximo ao hospital do estudo devido tempo de deslocamento para as atividades. Os que originariamente não eram desta região mudaram-se ao passar na residência.

"Eu morei com meus pais a vida inteira, ai eu saí de casa no internato e fui morar com duas amigas minhas aqui pertinho, com a facilidade de estar perto do hospital [...] então eu acabei me mudando pra cá” P2, fem.

"Eu tenho uma faxineira que me ajuda 1 vez por semana [...] a alimentação minha mãe também me ajuda, deixando algumas coisas congeladas, mas eu como predominantemente fora. Então dentro de 
casa, minhas funções são bem mínimas... não dá muito tempo, também”

P5, fem.

"Eu tenho uma diarista que vem uma vez por semana [...] eu faço a limpezas menores [...] geralmente quando eu tenho tempo em casa eu cozinho, alguma coisa, faço minhas alimentações, mas a maior parte das vezes eu acabo comendo fora mesmo, na rua, principalmente à noite"

$$
\text { P6, masc. }
$$

A presença de faxineiras / diaristas também aparecem nos relatos, de modo a auxiliar nas atividades domésticas. As refeições nos períodos dos estágios são realizadas quase que exclusivamente no restaurante do hospital, tanto pela questão de custo quanto de tempo para as refeições. Nenhum dos entrevistados moram atualmente com familiares. 2 residentes auxiliam nas contas de seus familiares e apenas 1 recebe ajuda financeira dos mesmos.

Não é incomum o consumo de grande parte do tempo destinado para folga, lazer ou estudo teórico para realização de outras atividades remuneradas que não a residência.

\section{“[...] eu nunca parei pra fazer conta mas com certeza trabalho muito} mais que 60hrs semanais porque tem a questão dos plantões externos que foi uma opção minha [...] eu descansei em todos [referindo-se aos plantões realizados no código azul] [...] eu conseguia dormir quase 
todo plantão e no dia seguinte você tem pós plantão então dava pra emendar com os plantões fora [...]"

P5, fem.

Dos 8 residentes entrevistados 7 exerciam outras atividades para complementar renda, realizando de 2 a 4 plantões de 12 horas no mês, a depender da disponibilidade de horário após as atividades da residência. O comportamento apresentado é referido nas entrevistas devido a busca de independência financeira, somando o valor bolsa da residência com os trabalhos extras para o alcance da mesma, sempre em regimes diferentes do CLT.

\section{d) Tempo para lazer e relacionamentos interpessoais}

Há relatos de intensa dificuldade para conciliar o tempo entre as atividades práticas, horas de estudo, outras atividades remuneradas e tempo para lazer, atividades domésticas e relacionamentos interpessoais.

“[...] resumindo, a residência é se adaptar a falta de tempo que é meio que uma falta de tempo crônica. A maior parte do dia você ocupa dentro do hospital por causa da residência então tem que adaptar os horários: diminuir a academia, dormir mais tarde porque quer ficar um pouco com o namorado [...] tem a parte financeira também que demanda um pouco mais de tempo e de organização, e tipo, fazer unha, cortar cabelo, fazer depilação; isso você faz quando dá [...] você acaba aprendendo a relevar e se adaptar de uma maneira diferente. No começo eu ficava tipo...meu Deus não está 
dando para fazer nada e eu ficava meio sofrida, mas hoje em dia vai super de boa..."

P5, fem.

"[...] acaba que realmente tem um cansaço, vou te falar que as vezes cansa, é pesado. Porque por mais que você acabe o estágio em um horário bom, você tem que estudar, então eu chegava em casa descansava um pouco e tinha que estudar, aí falava: academia para amanhã ... e acaba que não vai para a frente [...]"

$$
\text { P1, masc. }
$$

Percebe-se uma dificuldade para conciliação de horários, por vezes identificada como uma falta de tempo crônica. Nesta fase há uma reestruturação da agenda do jovem médico que geralmente vem acompanhada de queixas de fadiga crônica.

"[...] eu dei dois plantões noturnos esse final de semana, sexta e sábado [...] então eu dormi até uma hora da tarde pra tentar reconhecer o dia [...] eu falo que eu quero ser feliz...você quer ter umas horas acordadas de lazer, assistir Netflix, você não quer dormir direto apesar de estar com sono...é... ai hoje quando eu acordei eu até falei para o meu namorado: eu não sabia que eu estava tão cansada...[risos]...porque eu sai do hospital e meu corpo todo estava 
doendo. Não sei o que estava acontecendo, não sei se foi por causa do plantão $[\ldots]$ "

P8, fem.

"[...] mas eu tento me organizar para pelo menos uma vez por mês ou uma vez a cada 40 ou 50 dias livrar um fim de semana completo. Seja para ir viajar com o namorado ou uma festa no sábado à noite, ai eu deixo domingo para curar a ressaca, essas coisas, entendeu [...]"

P5, fem.

"[...] tem que escolher entre comer, dormir... e ficar um pouco com o namorado, ou falar com seus pais, ou ir na academia e cada dia você escolhe uma coisa"

P5, fem.

Muitas vezes o horário que era previsto para repouso / descanso é sacrificado para que o residente consiga algum tempo para lazer ou obrigações sociais (interações sociais, afetivas, festas, etc.).

“Contando com os plantões de fora acaba ficando um pouco pesado principalmente pela questão fisica mais também pela questão de querer ter um tempo livre para ver amigos, ter um tempo livre para ir pra casa sabe ... então você tem que se manter em São Paulo, tem que trabalhar fora [...] as vezes une o cansaço físico as vezes gera muitas 
dúvidas também né, putz será que eu fiz a coisa certa? Meus amigos já estão todos formado e não trabalham tanto como eu. Às vezes essas dúvidas acabam vindo [...] Eu penso que daqui algum tempo tudo vai se acalmar e eu vou poder compensar, né? Mais tempo com os amigos, com a família e outros relacionamentos"

P7, masc.

Aparece constantemente nos relatos a necessidade de complementar financeiramente à bolsa de residência. Como alternativa os residentes encaixam outros empregos nos horários livres, o que também compromete parte do tempo livre.

"Eu, que estou no mercado ainda, não tem tempo para se encontrar, sabe? Tipo às vezes estou interessado mas tem que esperar, tipo, uma semana, duas dependendo do estágio ou então acho que eu estou muito cansado, e aí fica parecendo que a gente enrola as pessoas e não é isso ... atrapalha bastante."

P6, masc.

“[...] a gente estava tentando montar um esquema de fim de semana sim e fim de semana não [referindo-se a ver o namorado] claro que não dava sempre certo, a gente já ficou o mês inteiro sem se ver... só que quando a gente fica muito tempo sem se ver é assim: pelo amor de D’uuss ... a gente fica desesperado, então o nosso ideal é de $15 \mathrm{em}$ 
15...quando dá, dá, e quando não dá, não dá! [...] plantão, não tem fim de semana livre aí não dá...é igual agora.... agora a gente está a três finais de semana sem se ver, ai a gente vai se ver nesse."

P8, fem.

“Teve um estágio especificadamente que foi o PSM, ai também eu dei muito plantão noturno, chegava em casa quase 9h, 9 e meia da manhã, dormia até as $18 \mathrm{~h}$ da tarde e ia para o plantão de novo, aí quando eu acordava, ela [referindo-se a ex-namorada] estava dormindo e vice e versa, foi o único atrito principal..." [terminou relacionamento de 2 anos e meio há 2 semanas desta entrevista]

P4, masc.

Assim como ocorre com a disponibilidade de tempo para lazer e relacionamentos interpessoais, há também interferência nos relacionamentos amorosos. Há relatos da dificuldade em conciliar o tempo disponível, tanto para início de relacionamentos quanto para a manutenção de relacionamentos.

"Eu comecei a namorar no ano passado, então final de semana à noite eu costumo sair e aproveitar com o namorado [...] mas assim, é meio desequilibrado, porque eu mais trabalho do que aproveito pra descansar [...] eu gosto de carinho, de contato, então ajudou bastante [...] ele entender 100\% o fato de eu dar plantão à noite, sábado, 
domingo... não interessa, tipo, se a gente consegue se encontrar em outros buracos da semana tá tudo certo, entendeu?"

P5, fem.

"Se eu tenho algum tempinho à noite é para tentar passar com ele, ai ele dá plantão também. Tem plantão fixo de terça-feira, ano passado ele tinha 2 plantões de PS por semana, então tinha semana que ele dava plantão terça, quarta, domingo e eu no sábado, e aí a gente se via 2 noites por semana."

P2, fem.

Para a manutenção dos relacionamentos é relatado a necessidade de adaptação da rotina dos casais. Em muitos casos, o relacionamento com outro médicos facilita a compreensão desta dinâmica.

\section{e) Planejamento familiar/filhos}

Sete dos oito entrevistados são solteiros e não possuem filhos. Um dos residentes é casado e aguardo o nascimento de um filho não planejado.

“[...] eu não me vejo estudando pra uma prova super concorrida com uma criança pequena em casa, sei que não iria dar certo [...] todo mundo que está em uma relação estável pensa nisso, em ter filho ... a gente, por ser médico, sabe que quanto mais você atrasa isso maior a chance de ter um filho com algum problema genético, alguma 
complicação na gestação ... então assim, você fica nesse equilíbrio fisico de balançar sua vida profissional e o risco de ter uma gestação com um monte de problemas [Entrevistador] E porque não ter filho agora? [Participante] Porque eu não iria conseguir estudar para a prova ... por causa da prova [referindo-se à prova que irá prestar para o concurso da próxima residência]."

P2, fem.

É marcante, no discurso das quatro residentes femininas, a impossibilidade de ter filhos no momento devido a concentração que estudar para a prova da especialidade ou para outra residência subsequente exige.

Abaixo segue relatos do único residente casado, cuja esposa é residente de pediatria, e que está aguardando o filho nascer.

“Assim, nós sempre tivemos a ideia de ter filho, e quando casou a gente sabia que se tiver filho vai ser muito bem vindo, mas não era na hora que a gente queria [...] pra ela vai ser muito mais trabalhoso porque vai ter que parar a residência e depois repor [...] vai ter que trabalhar grávida, dar plantão grávida. Então assim, é muito ruim." P1, masc.

"Agora que ela está gravida é impossivel ela trabalhar fora da residência e acaba que você tem que arrumar uma disponibilidade 
maior ainda para sustentar sua casa [...] você começa a ficar um pouco mais cansado porque trabalha fora mais vezes, acaba que prejudica a residência [...] ter menos tempo pra estudar, chegar as vezes mais cansado do seu dia-dia, e é isso atrapalha"

$$
\text { P1, masc. }
$$

"No princípio as pessoas foram super tranquilas [referindo-se a residência da esposa] - Você vai ter seu tempo de licença e tudo mais! Mas ai começa ter problema menores [...] em muitos estágios da pediatria eles coletam o exame de sangue dos pacientes e tem muito contato com perfuro cortante [...] mais risco de se furar. Ela esperava que o pessoal fosse ter um pouco mais de bom senso e até agora não tá rolando [...] o grupo de residente deu parabéns e tudo mais, mas isso é primeira impressão. Quando precisa trocar plantão, quando realmente precisa de ajuda aí não teve tanto apoio assim”

$$
\mathrm{P} 1 \text {, masc. }
$$

Como caso único neste estudo, foi selecionado trechos em que há descrição das modificações da rotina do participante e de sua esposa. Percebe-se no discurso que não há, de fato, um apoio ou estratégia institucional para lidar com médicas residentes gestantes. 


\section{f) Repouso/Sono}

O tempo disponível para repouso / sono varia entre os diversos estágios, sendo mais marcado a ausência deste nos estágios em Pronto - Socorros e Unidades de Terapia Intensivas. Em estágios de Enfermarias e Ambulatoriais, com exceção dos dias em que há plantões noturnos, esse tempo é relatado como mais adequado.

“Varia bastante! Por exemplo, nos estágios mais tranquilos, no caso, pegar o AGD que eu citei, dá pra dormir umas 7 horas por noite, 6 a 8 vai, menos nos dias de plantão noturno [...] você geralmente está dormindo 7 por noite normalmente, ai vem um plantão noturno e você só vai conseguir dormir as 9 da manhã do dia seguinte, isso não é no AGD é no eletivo, ai você desregula totalmente seu sono ... então apesar de você ter na maior parte do tempo conseguir dormir uma quantidade ok de horas, essa variação de horário prejudica bastante, isso nos tranquilos, nos pesados, UCI, UTI e tudo mais, 5 horas por noite, 4, 5, as vezes 6 vai dependendo."

P6, masc.

"Os dois estágios que eu dei de cara foi a uti e o pronto-socorro e teve essa questão: não pregava o olho a noite inteira, ficava tenso a noite inteira. Então, e aí o ruim era que chegava em casa e seu sono é muito ruim durante o dia [...] eu não recuperava, porque chegava em casa dormia 4 horas e acordava e não consegue mais dormir, ficava 
cansado e não recuperava, depois de uns dois dias que eu estou recuperado."

$\mathrm{P} 1$, masc.

Como já relatado, a privação de sono e o cansaço também impactam no desenvolvimento das tarefas.

"Acaba lentificando muito o processo [referindo-se ao sono atrapalhando o processo decisório] o que eu provavelmente poderia resolver muito rapidamente, eu precisava de mais tempo pra resolver [...] no pronto-socorro o plantão noturno é um pouco mais complicado [...] Há sempre coisas para fazer, porque são pacientes em geral de hospitais terciários: são mais graves, mais complexos [...] então mesmo se você tem poucos pacientes, e você está conseguindo lidar com todos eles, você ainda tem muitas coisas”

$$
\text { P6, masc. }
$$

"No plantão noturno tudo funciona mais devagar ... chega um momento do plantão que você já tá muito cansado, duas três da manhã você já tá lentificado, e as coisas no hospital também já estão mais lentificadas ... em alguns estágios a gente acaba ficando sozinho a noite, então você não consegue descansar [...] Sem contar que, tudo bem eu tenho um plantão noturno hoje á noite, nem por isso eu 
consigo descansar durante o dia para me preparar para um plantão [...] tipo eu estou seguindo a minha rotina, o meu dia a dia, eu não consegui fazer nada diferente, para mudar para descansar para esse plantão de hoje [...]"

$$
\text { P6, masc. }
$$

Por vezes, a tensão é externada em sonhos, dificuldade para dormir ou mesmo em um sono não repousante.

"[...] eu tenho uma facilidade para dormir graças a Jesus Cristo [...] em alguns estágios eu tinha umas alucinações [...] de você acordar e tipo: eu tenho que trocar não sei o que daquele paciente [risos] não prescrevi não sei o que lá, entendeu? Teve uma vez, na UCI, minha mãe estava lá em casa e aí eu acordei após plantão noturno. Eu acordei e ela estava na sala [...] eu fui até a sala e falei: tem que prescrever não sei o que ... aí minha mãe só olhou para mim e eu falei: eu estou viajando, né? [risos] aí eu voltei de novo para a cama e dormi. "

P8, fem.

Há diversos relatos de uso de café como estimulante para evitar ao sono. Em menor frequência, bebidas energéticas também são utilizadas. 
“[...] tinha plantão que realmente, por você estar mais cansado, tomava café, energético pra dar energia e poder aguentar [...] quando o plantão está muito tumultuado meio que fica tão na adrenalina ali que acaba não dando sono. Quando está muito cheio meio que o sono não aparecia, sabe? Às vezes estava uma coisa mais tranquila aí vai dando sono e dai acaba usando essas coisas pra dar uma segurada, mas de forma geral assim eu sempre levo energético para garantir o plantão $[\ldots]$ "

P7, masc.

\subsection{RESULTADOS DA $2^{\circ}$ FASE DO ESTUDO}

\subsubsection{Protocolos de atividades diárias}

Aceitaram participar desta fase 5 residentes do grupo do estágio do Pré-operatório e 2 (de 5) residentes do grupo do PSM, cuja caracterização foi realizada na Tabela 2. O modelo de protocolo de atividades diárias encontra-se no Anexo V.

Com os dados obtidos na aplicação dos protocolos de atividades diárias (coleta simultânea em agosto de 2017 com os grupos do $2^{\circ}$ ano de residência que estavam nos estágios Pré-op e PSM) foram montadas representações do ciclo atividade repouso, que seguem abaixo, nas figuras 2 a 8 .

Para estas representações foram selecionados os dados de repouso, atividade prática da residência e atividade remunerada não vinculada à residência. Os demais dados obtidos com os protocolos de atividades diárias encontram-se descritos nas Tabelas 6, 7 e 8. Após 
levantamento destes dados foram realizadas novas entrevistas com estes participantes para elucidação dos dados e aprofundamento sobre a percepção destes estágios.

O Participante P6, masculino, de 27 anos que estava no estágio de Avaliação Préoperatória na ocasião da coleta não realizou plantões em finais de semana e nem atividades remuneradas além das previstas na residência. Percebe-se a locação do sono principal no período noturno, com exceção do dia $19 / 08$ (sábado), sendo este deslocado para o período matutino devido atividades de lazer. Observa-se um maior tempo de duração de repouso nas noites de sexta (11 e 18/08), o que pode indicar uma compensação do repouso na folga, como segue na Figura 2.

Figura 2- Representação do ciclo atividade repouso do participante P6, São Paulo, Brasil, 2017.

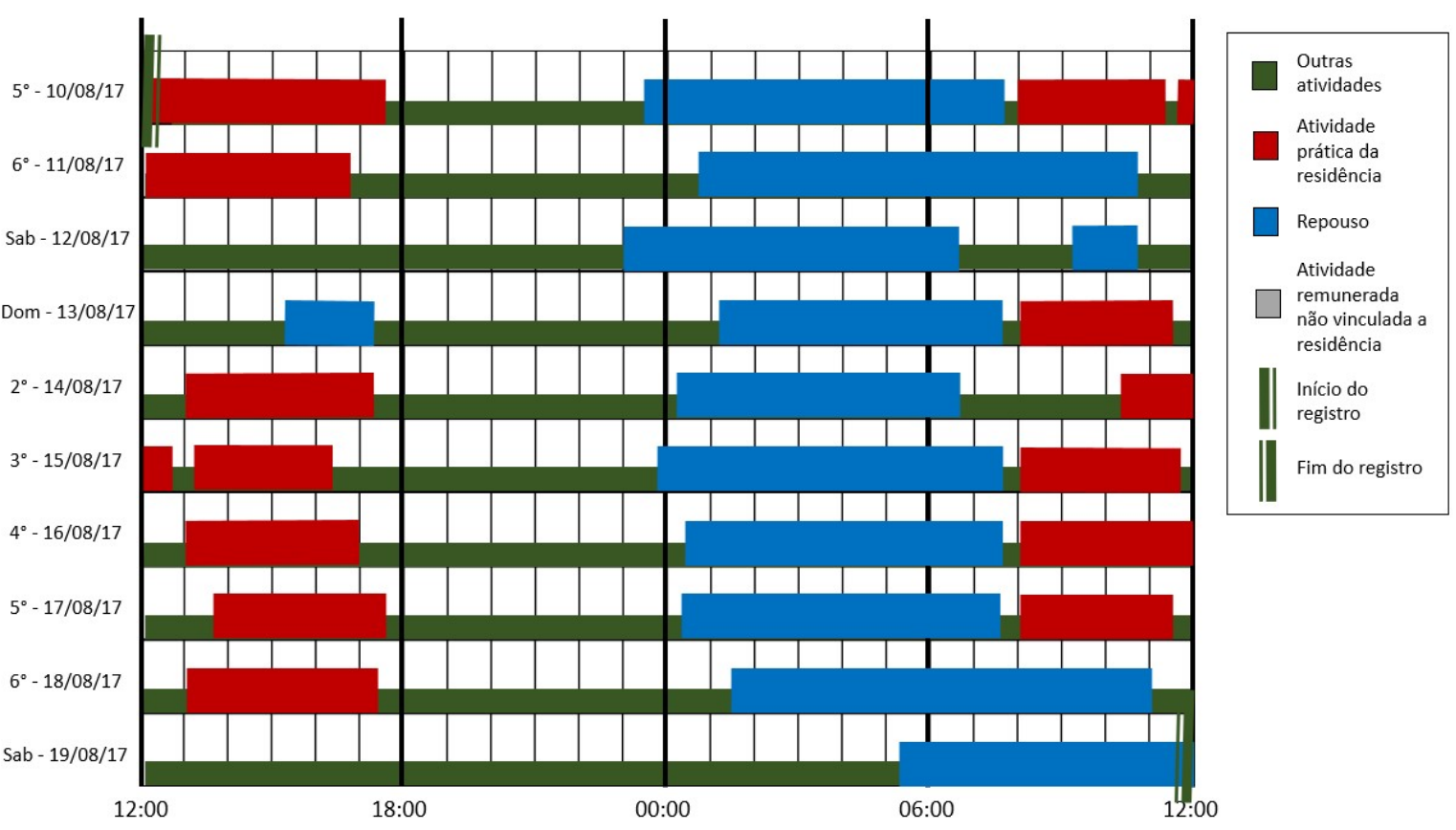

Fonte: Dados da pesquisa. Elaboração própria. 
O Participante P7, de 28 anos que estava no estágio de Avaliação Pré-operatória não realizou registro das atividades por 10 dias consecutivos. Percebe-se que há um tempo menor de duração do repouso noturno, principalmente dias 15 e 17/08, com a presença de repouso diurno em três dias. Realizou plantão pela residência de 12 horas diurnas no sábado (19/08) e no domingo (2008), o que eleva seu tempo em atividades da residência, mas não interfere na alocação de seu sono principal. No estágio analisado os residentes realizam apenas plantões diurnos pela residência, em finais de semana, não havendo plantões noturnos previstos, como demonstrado na Figura 3.

Figura 3- Representação do ciclo atividade repouso do participante P7, São Paulo, Brasil, 2017.

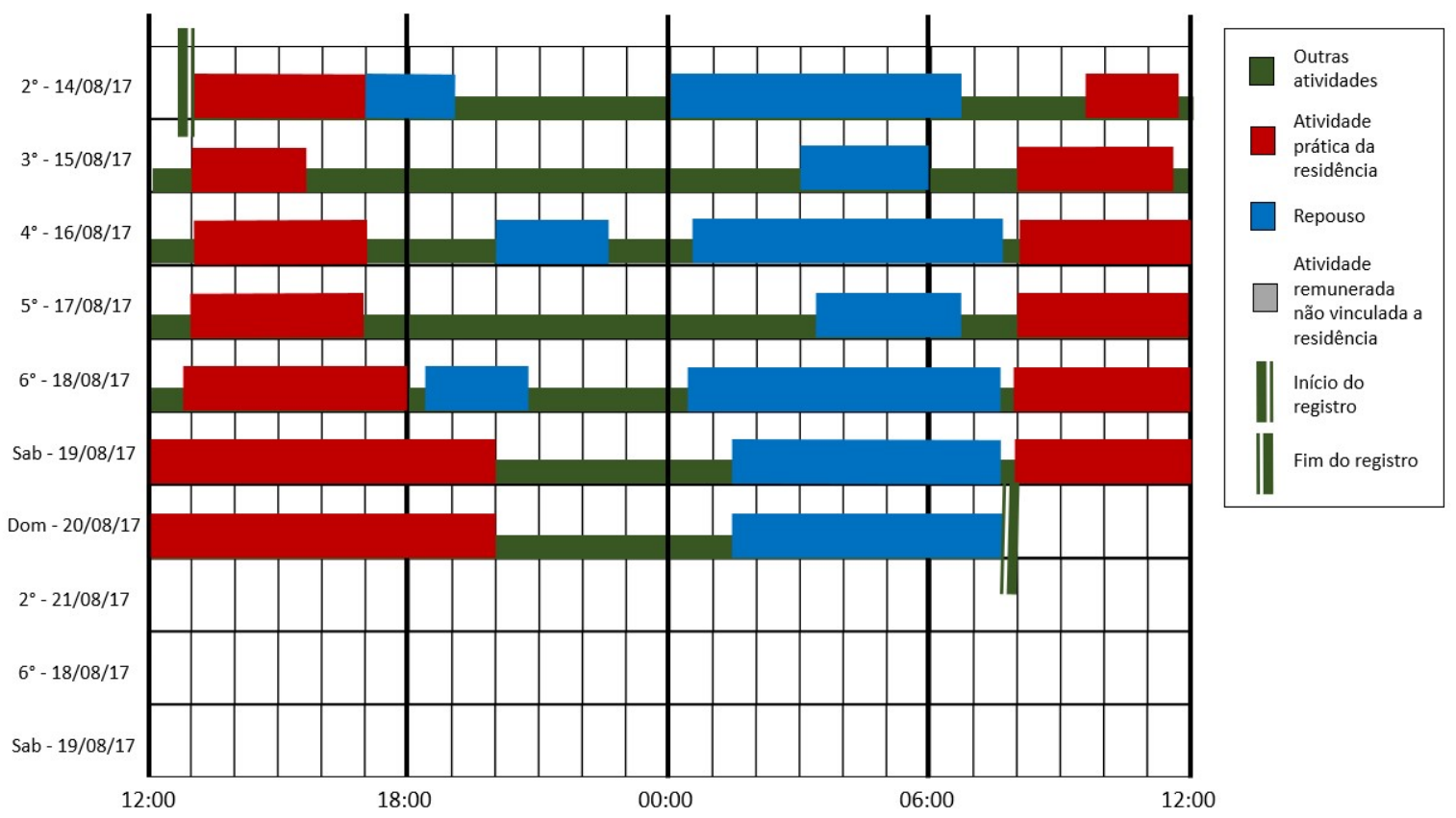

Fonte: Dados da pesquisa. Elaboração própria. 
A participante P10, feminina, com 27 anos, no momento da coleta encontrava-se no estágio de Avaliação Pré-operatória. Relata que frequentemente apresenta despertares perto das 06:00h, independente do estágio, mas que retorna o sono após usar o banheiro ou beber água. $\mathrm{Na}$ ocasião da coleta dos dados não realizou plantões em finais de semana e não realizou outras atividades remuneradas além das previstas na residência. No dia 11/08 no período da tarde terminou suas atividades da residência perto das 15:00 hs, deslocou-se para casa onde realizou um cochilo e retornou ao hospital para realizar uma avaliação pontual (interconsulta), atividade prevista neste estágio. Apresenta um padrão de repouso regular com extensão deste período aos sábados, como demonstrado na Figura 4.

Figura 4- Representação do ciclo atividade repouso do participante P10, São Paulo, Brasil, 2017.

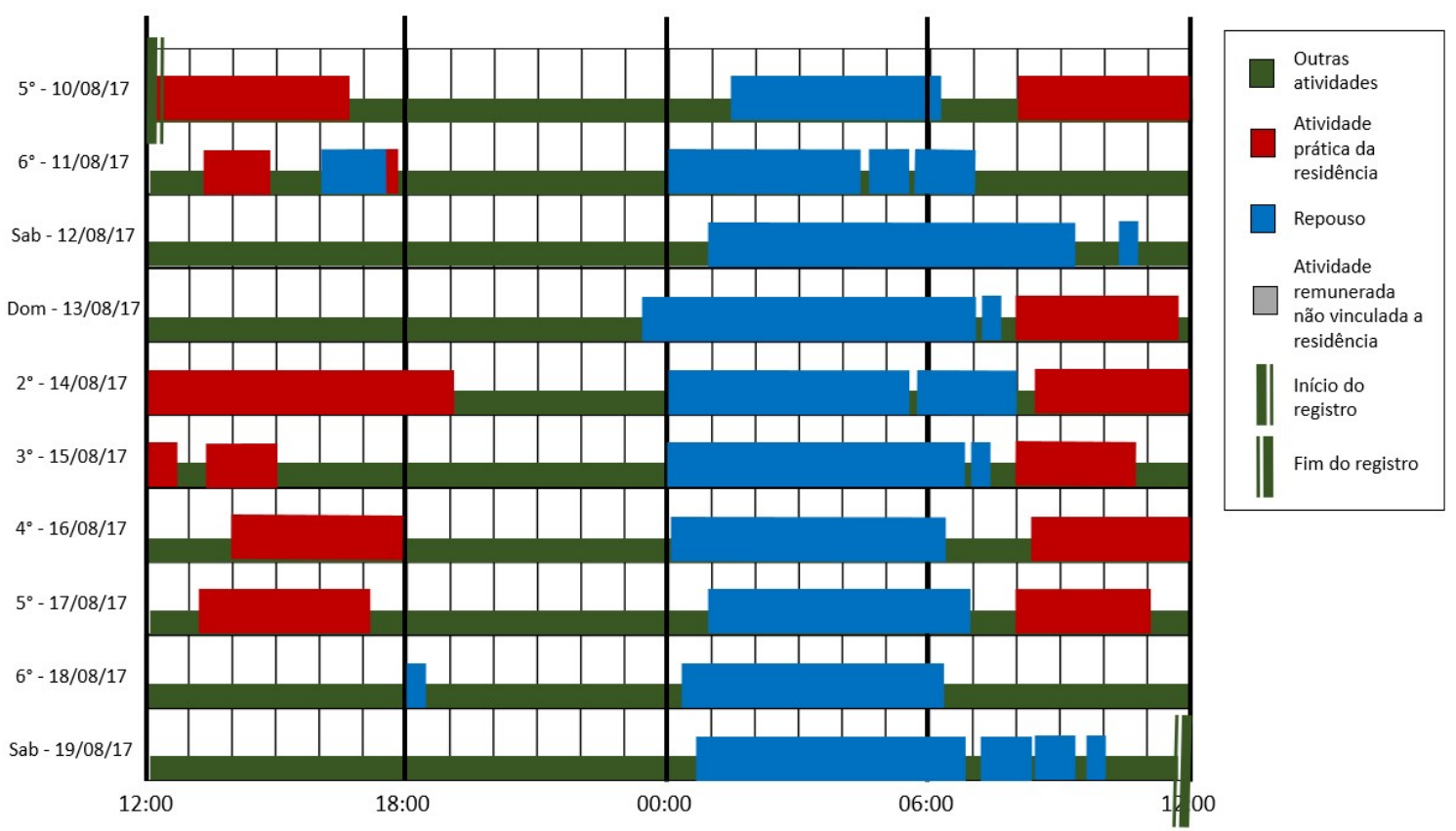

Fonte: Dados da pesquisa. Elaboração própria. 
Participante P8, feminina, de 25 anos que estava no estágio de Avaliação Pré-operatória realizou plantão diurno pela residência no domingo (13/08). Houve falha de registro do repouso/atividade após as 01:00 h até as 13:00 h do dia 14/08. No entanto, há o relato que a mesma desempenhou atividades normais da residência no período matutino do dia 14. Esta participante coletou dados por mais 3 dias (20, 21 e 22 de agosto) que não estão representados na Figura mas foram contabilizados na análise numérica. Dia 11/08 (sexta) não teve atividades pela residência no período da tarde, utilizando esse período para estudo teórico e outras atividades. Apresenta 2 horas de repouso (das 19:00 as 21:00) dias 10 e 1408, sendo que dia 14 este repouso adicional ocorre 1 dia após seu plantão diurno, de 12 horas, como demonstrado na Figura 5.

Figura 5- Representação do ciclo atividade repouso do participante P8, São Paulo, Brasil, 2017.

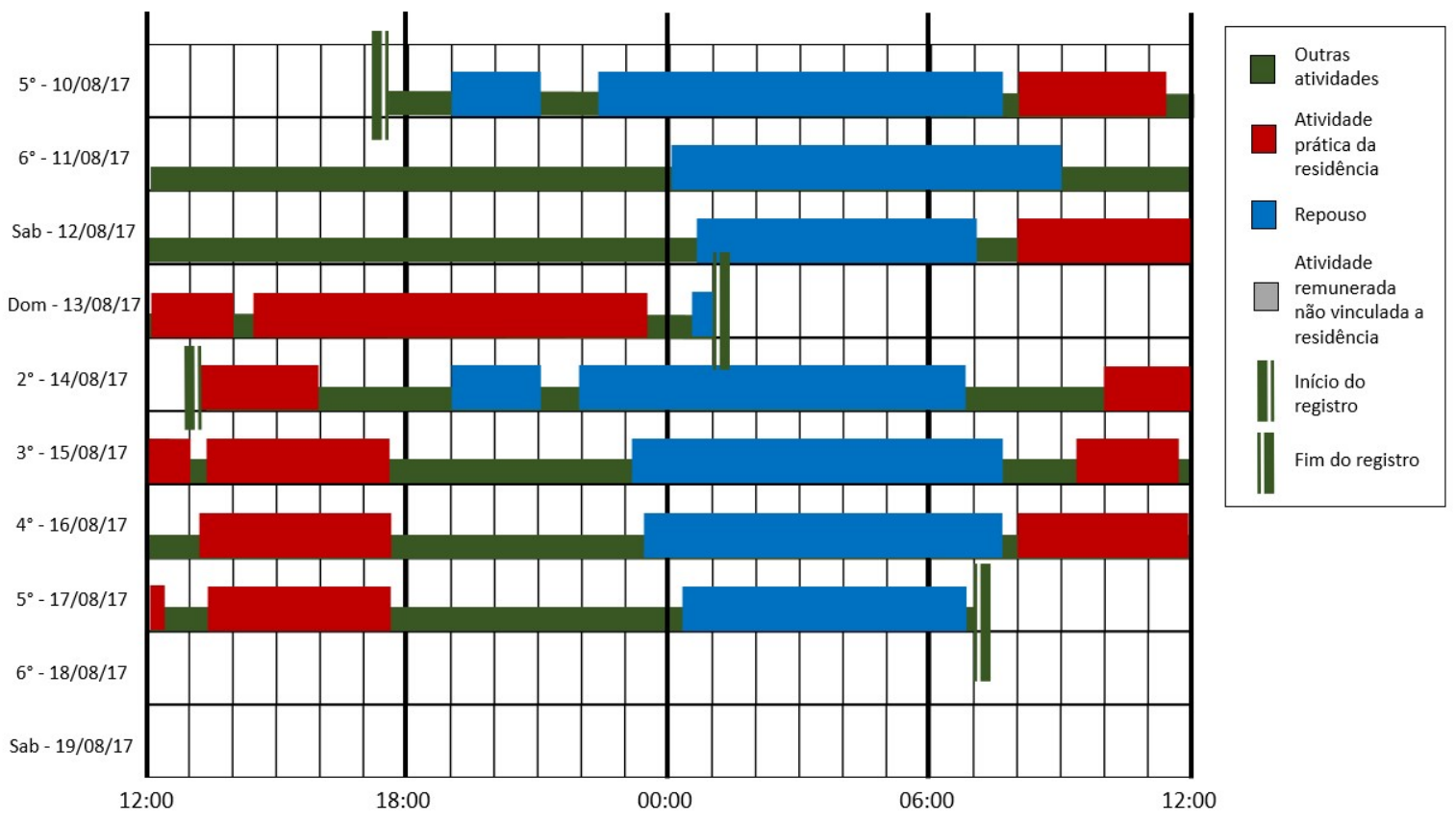

Fonte: Dados da pesquisa. Elaboração própria. 
Participante P9, masculino, de 27 anos que estava no estágio de Avaliação Pré-operatória foi o único dos participantes que desempenhou atividades remuneradas não vinculadas à residência durante a coleta. Também realizou plantão diurno pela residência no sábado, dia 12.08. Houve descontinuidade na coleta dos dados, sendo retomada a coleta do mesmo 6 dias após seu término. Os dados foram mantidos por tratar-se de um caso índice para o estudo. Percebe-se que há períodos para repouso durante os plantões realizados em outros serviços, sendo que realizou plantão noturno na sexta-feira dia 11/08, plantão diurno no domingo 13/08 e plantão diurno e noturno no domingo dia 2008. Apesar destes plantões, seu repouso principal continua locado no período noturno devido à possibilidade de repouso durante parte da jornada de trabalho, como demonstrado na Figura 9.

Figura 6- Representação do ciclo atividade repouso do participante P9, São Paulo, Brasil, 2017.

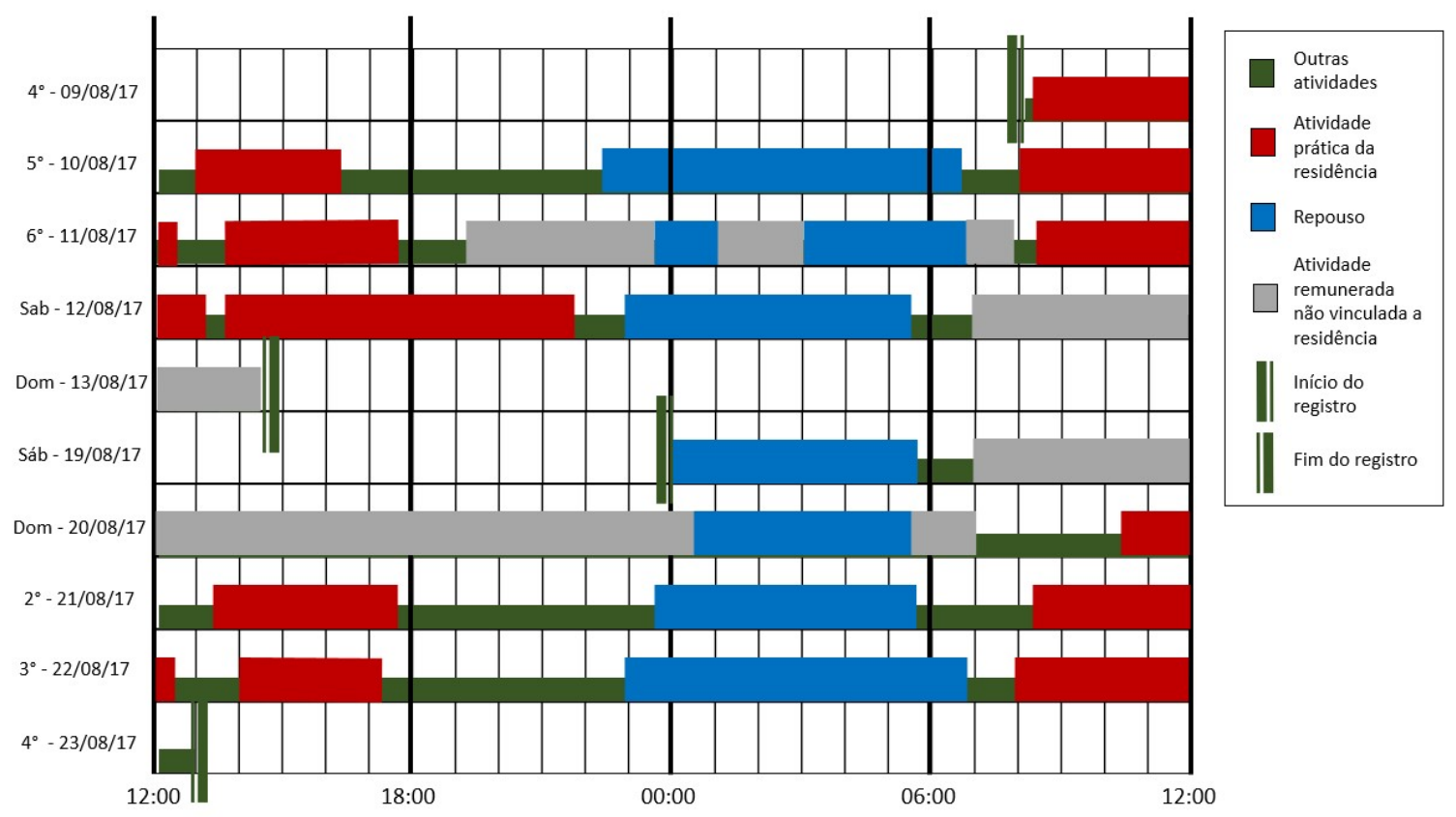

Fonte: Dados da pesquisa. Elaboração própria. 
O Participante P11, masculino, de 26 anos, na ocasião da coleta de dados estava no estágio de Pronto-Socorro de Clínica Médica, o qual é dividido em plantões de 12 horas, noturnos e diurnos, incluindo finais de semana. Os plantões são divididos entre plantões em sala de emergência e plantões nas "macas do PS" (pacientes em observação ou que estão aguardando leito para internação). Durante este estágio, que durou 30 dias, este residente realizou 14 plantões diurnos e 7 noturnos, usufruindo de 9 dias de folga. Nota-se o deslocamento do repouso para o período diurno quando há plantões noturnos. Apesar do deslocamento do repouso, há certa regularidade no tempo de duração). Nota-se que não ocorrem períodos de repouso durante os plantões, ao contrário do observado nos plantões remunerados.

Figura 7- Representação do ciclo atividade repouso do participante P11, São Paulo, Brasil, 2017.

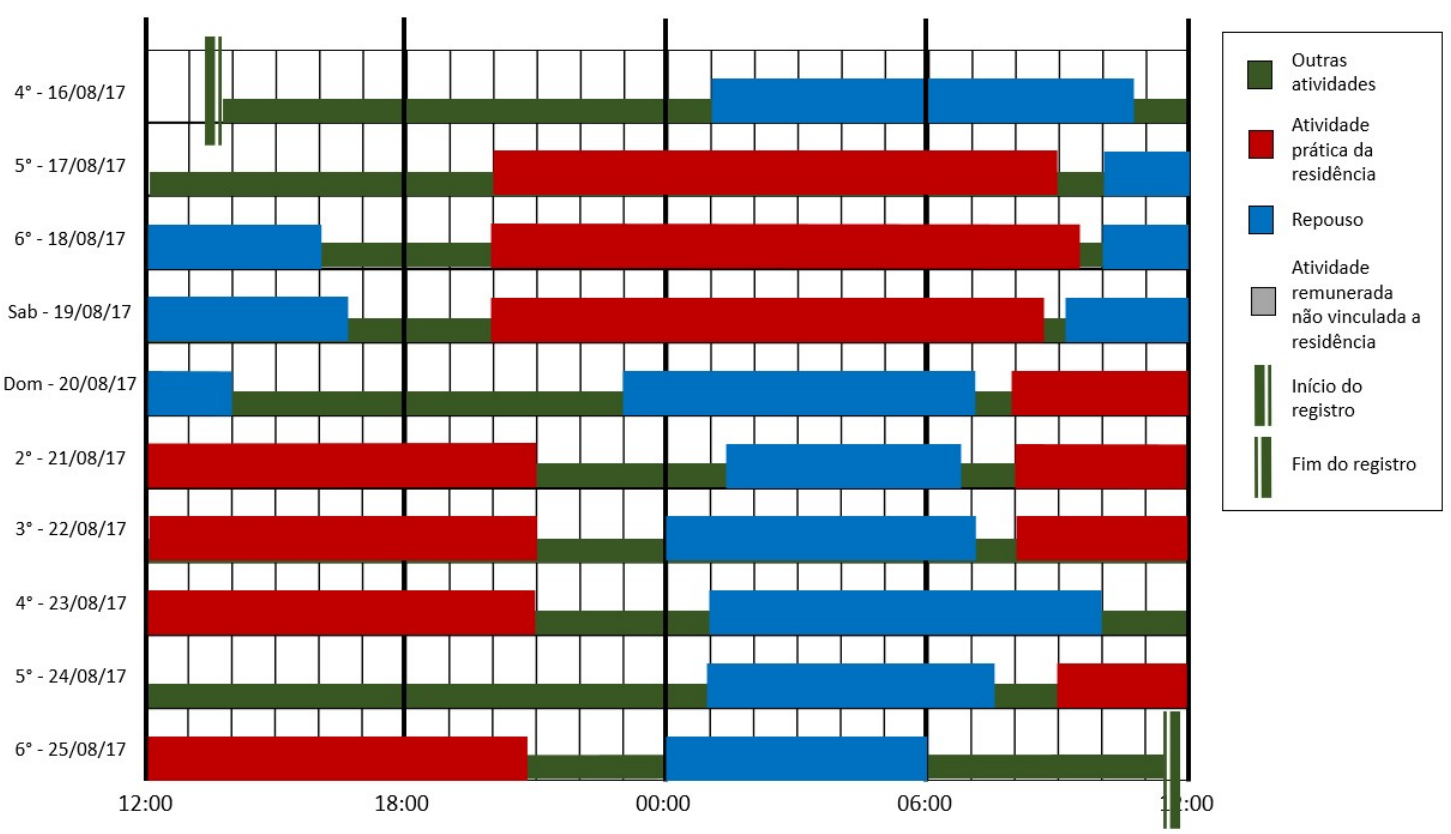

Fonte: Dados da pesquisa. Elaboração própria. 
Participante P12, masculino, de 26 anos que estava no estágio de Pronto-Socorro de Clínica Médica, realizou 15 plantões diurnos e 6 noturnos, usufruindo de 9 dias de folga, em 30 dias de estágio. Assim como no participante anterior, percebe-se que, ao subtrair o tempo de atividade da residência e o tempo para repouso, não há tempo vago para outras atividades durante o estágio.

Figura 8- Representação do ciclo atividade repouso do participante P12, São Paulo, Brasil, 2017.

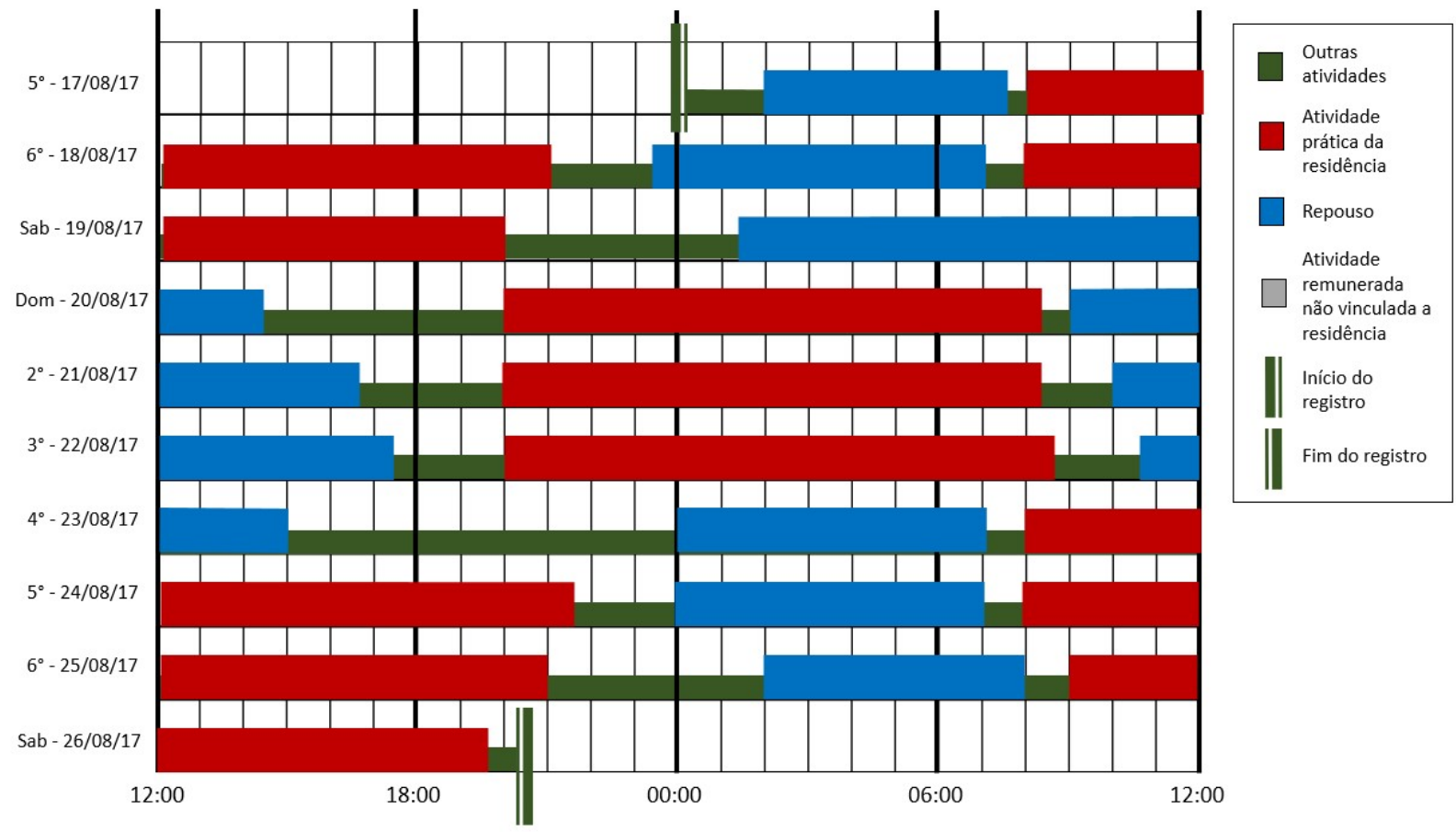

Fonte: Dados da pesquisa. Elaboração própria.

Com os 5 primeiros casos (estágio de avaliação pré-operatória), percebe-se que durante este estágio, o repouso é locado no período noturno. Há regularidade nos períodos de 
atividade da residência e no padrão do repouso dos residentes. São previstos tempos livres compatíveis com outras atividades, que são usados para estudo, lazer ou até mesmo plantões remunerados em outras instituições.

Consolidando os dados dos outros 2 participantes (estágio do pronto-socorro da clínica médica), percebemos que este estágio, durante a realização de plantões noturnos, promove o deslocamento do repouso para o período diurno, além de possuir uma alta demanda de carga horária, tornando muito difícil a prática de outras atividades como estudo teórico ou atividades de lazer durante este estágio.

Utilizando-se os protocolos de atividades diárias foi considerado a atividade realizada depois do repouso principal para classificar o período em dias de atividade prática na residência, dias com plantão da residência em final de semana, dias de folga e dias com atividades práticas na residência e com outro trabalho remunerado.

Foram calculados o tempo de repouso noturno (TRN), o tempo de repouso diurno (TRD), tempo de repouso total (TRT), tempo em atividades práticas da residência (TAR), tempo com estudo teórico (TET), tempo com outras atividades remuneradas que não a residência trabalho (TT) e tempo com atividades de lazer (TL).

Foram calculadas as médias para cada participante e, em seguida, agrupados conforme o estágio em que estavam passando na época, calculada a média, mediana e desvio padrão para os grupos.

O grupo 1 desenvolveu atividades no estágio de avaliação pré-operatória, atividade ambulatorial para avaliação de pacientes que serão submetidos à cirurgias. Durante este são realizados plantões diurnos aos finais de semana em hospital secundário, conforme a Tabela 3. 
Considerando a mediana, em dias com atividades práticas da residência o tempo de repouso noturno foi de $6,7 \mathrm{~h}$, durante a realização dos plantões previstos na residência $6,5 \mathrm{~h}$ e em dias de folga $8,5 \mathrm{~h}$. O tempo em atividades da residência para dias sem plantão foi de 7,0 h enquanto para dias com plantão foi de $12,0 \mathrm{~h}$.

O tempo destinado para lazer, em dias com plantões foi de 5,0 h, enquanto no dia sem plantão foi de 2,5 h e para dia de folga 6,7 h. Não houve tempo para estudo teórico nos dias de plantão pela residência, sendo este 2,8 h nos dias de folga e 2,2 nos dias de atividade sem plantão.

O participante P9 foi o único que realizou atividades remuneradas não vinculadas a residência no período da coleta, apresentado tempo de repouso noturno de $3,7 \mathrm{~h}$ no dia em que desenvolveu 7,2 h desta atividade (plantão noturno de $12 \mathrm{~h}$ ) e 5,0 h no dia em que desenvolveu 18,5 h (plantão com duração de 24 h). Dados completos seguem na Tabela 6.

Tabela 6- Tempo (em horas) despendido nas atividades ou repouso dos residentes do segundo ano que estavam no estágio de Avaliação Pré-Operatória, São Paulo, Brasil, 2017.

\begin{tabular}{|c|c|c|c|c|c|c|c|c|c|c|}
\hline & TRN & TRN 2 & TRD 1 & TRD2 & TRT & TAR & TET & TT & TL & $\begin{array}{c}\text { Tempo } \\
\text { Total } \\
\text { Avaliado }\end{array}$ \\
\hline \multicolumn{11}{|c|}{ Dia com atividade prática na residência } \\
\hline Média do participante P6 & 6,7 & 0 & 0 & 0 & 6,7 & 7,5 & 2,2 & 0 & 3,1 & 19,6 \\
\hline Média do participante P7 & 4,9 & 0,6 & 0,5 & 0 & 6,0 & 7,6 & 1,0 & 0 & 1,6 & 16,3 \\
\hline Média do participante P8 & 7,6 & 0 & 0 & 0 & 7,6 & 5,4 & 2,3 & 0 & 1,8 & 17,2 \\
\hline Média do participante $\mathrm{P} 9$ & 7,1 & 0 & 0 & 0 & 7,1 & 7,8 & 1,7 & 0 & 1,2 & 21,6 \\
\hline Média do participante P10 & 6,5 & 0 & 0,2 & 0 & 6,8 & 7,0 & 3,1 & 0 & 2,1 & 19,2 \\
\hline Média do Grupo 1 & 6,5 & 0,1 & 0,1 & 0,5 & 7,0 & 6,4 & 2,2 & $\mathbf{0}$ & 3,5 & 16,9 \\
\hline Mediana do Grupo 1 & 6,7 & $\mathbf{0}$ & $\mathbf{0}$ & $\mathbf{0}$ & 7,0 & 7,5 & 2,2 & $\mathbf{0}$ & 2,5 & 18,5 \\
\hline Desvio Padrão do Grupo 1 & 2,2 & 0,5 & 0,5 & 1,6 & 2,2 & 2,5 & 2,0 & $\mathbf{0}$ & 4,8 & 6,2 \\
\hline
\end{tabular}


(continuação)

\begin{tabular}{|c|c|c|c|c|c|c|c|c|c|c|}
\hline & TRN & TRN 2 & TRD 1 & TRD2 & TRT & TAR & TET & TT & TL & $\begin{array}{c}\text { Tempo } \\
\text { Total } \\
\text { Avaliado }\end{array}$ \\
\hline \multicolumn{11}{|c|}{ Dias com plantão da residência em final de semana } \\
\hline Média do participante P7 & 6,5 & 0 & 0 & 0 & 6,5 & 12,0 & 0 & 0 & 5,2 & 23,7 \\
\hline Participante P8 & 6,5 & 0 & 0 & 0 & 6,5 & 15,0 & 0 & 0 & 0 & 21,5 \\
\hline Média do Grupo 1 & 6,5 & $\mathbf{0}$ & $\mathbf{0}$ & $\mathbf{0}$ & 6,5 & 13,0 & 0 & 0 & 3,5 & 23,0 \\
\hline Mediana do Grupo 1 & 6,5 & $\mathbf{0}$ & $\mathbf{0}$ & $\mathbf{0}$ & 6,5 & 12,0 & 0 & 0 & 5,0 & 23,5 \\
\hline Desvio Padrão do Grupo 1 & 0,5 & $\mathbf{0}$ & $\mathbf{0}$ & $\mathbf{0}$ & 0,5 & 1,7 & 0 & 0 & 3,0 & 1,3 \\
\hline \multicolumn{11}{|l|}{ Dias de Folga } \\
\hline Média do participante P6 & 6,5 & 0 & 2,3 & 0,4 & 9,3 & 0 & 1,1 & 0 & 7,5 & 17,9 \\
\hline Participante P8 & 9,0 & 0 & 0 & 0 & 9,0 & 0 & 3,7 & 0 & 7,5 & 20,2 \\
\hline Média do participante P10 & 7,0 & 0 & 0 & 0 & 7,0 & 0 & 3,3 & 0 & 4,5 & 14,8 \\
\hline Média do Grupo 1 & 7,0 & $\mathbf{0}$ & 1,0 & 0,1 & 8,2 & $\mathbf{0}$ & 2,3 & $\mathbf{0}$ & 6,1 & 16,8 \\
\hline Mediana do Grupo 1 & 8,5 & $\mathbf{0}$ & $\mathbf{0}$ & $\mathbf{0}$ & 8,5 & $\mathbf{0}$ & 1,5 & $\mathbf{0}$ & 6,7 & 17,5 \\
\hline Desvio Padrão do Grupo 1 & 3,1 & $\mathbf{0}$ & 2,7 & 0,6 & 1,6 & $\mathbf{0}$ & 2,8 & $\mathbf{0}$ & 1,7 & 2,8 \\
\hline \multicolumn{11}{|c|}{ Dias com plantão na residência em final de semana e com outro trabalho remunerado } \\
\hline Participante P9 & 3,7 & 1,2 & 0 & 0 & 5,0 & 12,5 & 0 & 7,2 & 0 & 24,7 \\
\hline \multicolumn{11}{|c|}{ Dias com atividade prática na residência e com outro trabalho remunerado } \\
\hline Participante P9 & 5,0 & 0 & 0 & 0 & 5,0 & 5,5 & 3,0 & 18,5 & 2,5 & 34,5 \\
\hline
\end{tabular}

Fonte: Dados da pesquisa. Elaboração própria.

Nota: TRN: tempo de repouso noturno; TRD: tempo de repouso diurno; TRT: tempo de repouso total; TAR: tempo de atividade na residência; TET: tempo de estudo teórico; TT: tempo de trabalho; TL: tempo de lazer

O grupo 2 desenvolveu atividades no estágio do Pronto-Socorro de Clínica Médica, onde prestam assistência a pacientes graves encaminhados de outras unidades deste e de outros hospitais, realizando plantões de 12 horas, noturnos e diurnos.

Considerando a mediana, em dias de folga o tempo de repouso total foi $4,7 \mathrm{~h}$, para dias de plantão noturno $7,1 \mathrm{~h}$ e para dia de plantão diurno $7,0 \mathrm{~h}$. O tempo em atividades da residência para dias com plantão diurno foi de $13,0 \mathrm{~h}$ e para plantão noturno de foi de $12,5 \mathrm{~h}$.

O tempo destinado para lazer, em dias com plantões foi de 5,0 h, enquanto no dia sem plantão foi de 2,5 h e para dia de folga 6,7 h. Para os dias de plantão noturno e para os dias de folga (após a realização de plantão noturno) o tempo de repouso está locado no período 
diurno, conforme podemos verificar nas figuras 7 e 8 . Não houve tempo para estudo teórico neste grupo. O tempo para atividades de lazer foi de $1,7 \mathrm{~h}$ no período de plantão diurno, $2,5 \mathrm{~h}$ no período de plantão noturno e 3,0 h nos dias de folga. Dados completos na Tabela 7.

Tabela 7- Tempo (em horas) despendido nas atividades ou repouso dos residentes do segundo ano que estavam no estágio do Pronto-Socorro de Clínica Médica, São Paulo, Brasil, 2017.

\begin{tabular}{|c|c|c|c|c|c|c|c|c|}
\hline & TRN & TRD & TRT & TAR & TET & TT & TL & $\begin{array}{c}\text { Tempo Total } \\
\text { Avaliado }\end{array}$ \\
\hline \multicolumn{9}{|c|}{ Dias com atividade prática na residência (plantão diurno) } \\
\hline Média do Participante P11 & 6,9 & 0 & 6,9 & 12,9 & 0,8 & 0 & 2,5 & 23,2 \\
\hline Média do Participante P12 & 7,3 & 0 & 7,3 & 12,7 & 0 & 0 & 2,7 & 22,8 \\
\hline Média do Grupo 2 & 7,1 & $\mathbf{0}$ & 7,1 & 12,8 & $\mathbf{0 , 4}$ & $\mathbf{0}$ & 2,6 & 23,0 \\
\hline Mediana do Grupo 2 & 7,0 & $\mathbf{0}$ & 7,0 & 13,0 & $\mathbf{0 , 0}$ & $\mathbf{0}$ & 1,7 & 21,7 \\
\hline Desvio Padrão do Grupo 2 & 2,4 & $\mathbf{0}$ & 2,4 & 0,4 & $\mathbf{0 , 8}$ & $\mathbf{0}$ & 2,4 & 3,8 \\
\hline \multicolumn{9}{|c|}{ Dias com atividade prática na residência (plantão noturno) } \\
\hline Média do Participante P11 & 0 & 5,3 & 5,3 & 13,0 & 0,2 & 0 & 1,8 & 20,5 \\
\hline Média do Participante P12 & 0 & 7,5 & 7,5 & 12,3 & 0 & 0 & 2,5 & 20,3 \\
\hline Média do Grupo 2 & $\mathbf{0}$ & 6,4 & 6,4 & 12,6 & $\mathbf{0 , 1}$ & $\mathbf{0}$ & 2,1 & 21,4 \\
\hline Mediana do Grupo 2 & $\mathbf{0}$ & 7,1 & 7,1 & 12,5 & $\mathbf{0}$ & $\mathbf{0}$ & 2,5 & 21,3 \\
\hline Desvio Padrão do Grupo 2 & $\mathbf{0}$ & 1,6 & 1,6 & 0,5 & 0,2 & $\mathbf{0}$ & 0,6 & 1,0 \\
\hline \multicolumn{9}{|l|}{ Dias de folga } \\
\hline Participante P11 & 4,5 & 2,3 & 6,8 & 0 & 3,5 & 0 & 0 & 10,3 \\
\hline Participante P12 & 0 & 4,5 & 4,5 & 0 & 0 & 0 & 4,0 & 8,5 \\
\hline Média do Grupo 2 & 3,0 & 3,0 & 6,0 & $\mathbf{0}$ & 2,3 & $\mathbf{0}$ & 3,3 & 11,7 \\
\hline Mediana do Grupo 2 & $\mathbf{0}$ & 4,5 & 4,7 & $\mathbf{0}$ & $\mathbf{0}$ & $\mathbf{0}$ & 3,0 & 8,5 \\
\hline Desvio Padrão do Grupo 2 & 5,1 & 2,6 & 2,5 & $\mathbf{0}$ & 5,0 & $\mathbf{0}$ & 0,5 & 6,2 \\
\hline
\end{tabular}

Fonte: Dados da pesquisa. Elaboração própria.

Nota: TRN: tempo de repouso noturno; TRD: tempo de repouso diurno; TRT: tempo de repouso total; TAR: tempo de atividade na residência; TET: tempo de estudo teórico; TT: tempo de trabalho; TL: tempo de lazer

No grupo 2 percebe-se uma elevada carga horária de atividades práticas da residência, sendo que quase a totalidade do tempo do residente divide-se entre as atividades práticas da residência (representados pela cor vermelha nas figuras e o TAR nas tabelas) e o tempo para repouso (representados pela cor azul nas figuras e TRN, TRD e TRT nas tabelas). 
Há deslocamento do repouso para o período diurno nos dias com plantões noturnos e nos de folga, sendo que estas acontecem após plantões noturnos e ausência de tempo para estudo.

Ao comparamos as medianas dos grupos, para dias de atividade prática na residência percebemos valores semelhantes para períodos com plantões, mas menor para o $1^{\circ}$ grupo no período sem esta atividade.

Ao final do protocolo, os participantes marcaram sua percepção da qualidade do sono e de bem-estar ao acordar, tanto para o repouso noturno quanto diurno. Essa marcação ocorreu em escala visual de $10 \mathrm{~cm}$, sendo 10 a melhor situação e 0 a pior. Considerando as medianas, a percepção da qualidade do sono noturno, para os dois grupos, recebeu nota 6 , enquanto a do sono diurno 4,5. As médias individuais e em grupo, a mediana e o desvio padrão estão apresentados na Tabela 8, abaixo.

Tabela 8 - Médias individuais e em grupo de autoavaliações (escala visual analógica de zero a dez cm) dos participantes sobre a percepção da qualidade do sono e do bem-estar ao acordar, São Paulo, Brasil, 2017.

\begin{tabular}{lcccc}
\hline & \multicolumn{2}{c}{ SONO NOTURNO } & \multicolumn{2}{c}{ SONO DIURNO } \\
\hline & $\begin{array}{c}\text { Percepção da } \\
\text { qualidade do sono }\end{array}$ & $\begin{array}{c}\text { Percepção de bem- } \\
\text { estar ao acordar }\end{array}$ & $\begin{array}{c}\text { Percepção da } \\
\text { qualidade do sono }\end{array}$ & $\begin{array}{c}\text { Percepção de bem- } \\
\text { estar ao acordar }\end{array}$ \\
\hline Grupo 1 & & & & 3,0 \\
\hline Média do Participante 6 & 5,6 & 5,4 & 4,0 & 5,2 \\
Média do Participante 7 & 3,4 & 3,1 & 4,5 & 4,8 \\
Média do Participante 8 & 6,6 & 6,1 & 5,5 & -- \\
Média do Participante 9 & 5,9 & 5,3 & -- & 7,8 \\
Média do Participante 10 & 7,3 & 5,9 & 9,3 & $\mathbf{5 , 2}$ \\
Média do Grupo 1 & $\mathbf{5 , 9}$ & $\mathbf{5 , 3}$ & $\mathbf{5 , 7}$ & $\mathbf{5 , 0}$ \\
Mediana do Grupo 1 & $\mathbf{6 , 0}$ & $\mathbf{5 , 5}$ & $\mathbf{4 , 5}$ & $\mathbf{1 , 8}$ \\
Desvio Padrão do Grupo 1 & $\mathbf{2 , 2}$ & $\mathbf{2 , 3}$ & $\mathbf{2 , 2}$ &
\end{tabular}


(continuação)

\begin{tabular}{lcccc}
\hline & \multicolumn{2}{c}{ SONO NOTURNO } & \multicolumn{2}{c}{ SONO DIURNO } \\
\hline & $\begin{array}{c}\text { Percepção da } \\
\text { qualidade do sono }\end{array}$ & $\begin{array}{c}\text { Percepção de bem- } \\
\text { estar ao acordar }\end{array}$ & $\begin{array}{c}\text { Percepção da } \\
\text { qualidade do sono }\end{array}$ & $\begin{array}{c}\text { Percepção de bem- } \\
\text { estar ao acordar }\end{array}$ \\
\hline Grupo 2 & & & & \\
\hline Média do Participante 11 & 5,4 & 6,1 & 4,3 & 5,2 \\
Média do Participante 12 & 6,0 & 6,3 & 3,6 & 5,1 \\
Média do Grupo 2 & $\mathbf{5 , 8}$ & $\mathbf{6 , 2}$ & $\mathbf{3 , 9}$ & $\mathbf{5 , 1}$ \\
Mediana do Grupo 2 & $\mathbf{6 , 0}$ & $\mathbf{6 , 0}$ & $\mathbf{4 , 5}$ & $\mathbf{4 , 5}$ \\
Desvio Padrão do Grupo 2 & $\mathbf{2 , 5}$ & $\mathbf{1 , 8}$ & $\mathbf{1 , 7}$ & $\mathbf{2 , 2}$ \\
\hline
\end{tabular}

Fonte: Dados da pesquisa. Elaboração própria.

\subsubsection{Entrevistas da $2^{\circ}$ fase do estudo}

Quatro residentes participantes da $2^{\circ}$ fase do estudo aceitaram realizar uma segunda entrevista após a coleta dos protocolos, comparando os 2 estágios avaliados (Avaliação préoperatória e Pronto-socorro da Clínica Médica).

No discurso dos residentes é marcante a pressão psicológica e sobrecarga física do Pronto-Socorro de Clínica Médica (PSM). Há uma sobrecarga física devido ao número de horas de atividades diárias e uma sobrecarga emocional, caracterizada tanto pela gravidade e complexidade dos casos quanto pela responsabilidade de comandar a salas de emergência.

“[...] há sobrecarga nas áreas física e emocional, tanto o PSM quanto o Pronto Atendimento do Hospital Universitário [...] primeiro ponto a questão dos plantões noturnos [...] e $2^{\circ}$ que quando você está lá você não para nem um segundo. Quando você está no ambiente da terapia intensiva ou no ambulatório você tem atividades que tem interrupções, no pronto-socorro você tem a sensação que a qualquer instante a 
coisa pode agudizar [referindo-se à chegada de muitos pacientes ou de pacientes graves]. Então, eu acho que isso dá uma sensação para a gente de maior sobrecarga."

P12, masc.

“[...] Então apesar de ser um estágio que você tem um crescimento intelectual, um crescimento pelos casos, pelo que você vê dos pacientes, você também é sugado! Você fica muito exausto por conta das burocracias que você precisa resolver, das relações interpessoais com os familiares e com a equipe médica e entre os residentes também. Porque você tem que olhar para o R1, você tem que olhar para o interno... muita sobrecarga!”

P10, fem.

“No R2 você é o responsável pela sala de emergência, né? Então acho que esse é um elemento bem significativo [...] existe esse elemento de tensão associado a uma instabilidade muito grande [...] diria que foi um mês muito intenso, do ponto de vista físico mesmo, mas eu diria que eu gostei do mês, assim, porque realmente foi de muito aprendizado.”

P12, masc. 
Neste estágio há um menor tempo disponível para o convívio com amigos, familiares e lazer. Apesar das sobrecargas já relatadas, é caracterizado pelos residentes como um estágio de aprendizado intenso.

"Foi um mês bom mas não resta duvidas que com certeza eu interagi menos com o resto da minha vida, né? Eu estive menos com a minha namorada, eu fiz menos atividade física, então assim, elementos que são importantes na minha vida ficaram um pouco em segundo plano ... acho que esse tem sido um dos meses da residência em que eu menos tenha visto a minha família ... pensando a grosso modo foi um mês de muito sacrificio na minha vida pessoal."

P12, masc.

“Vida pessoal é meio que teste... é muito ruim, não tem nem muito o que comentar... é horrível! Você não consegue ter contato com ninguém. Um mês em que realmente você é abduzido [...] e aí chega no final do mês isso cansa, né? Para todo mundo que convive com você ... fica mais estressado ... essas coisas que somam, então isso só contribui para ficar pior essa sobrecarga de trabalho."

P10, fem. 
O sono diurno é relatado como "não reparador". Soma-se a isso a privação de sono durante e após os plantões noturnos como fatores complicadores para a gestão do tempo neste estágio.

“No pós-plantão noturno aquele seu sono diurno ele nunca é um sono tão reparador do sono noturno [...] o fato da gente fazer algumas noites seguidas faz com que seu corpo se acostume um pouco então você consegue descansar um pouco mais de dia, e você não perde tantos dias do mês."

$$
\text { P12, masc. }
$$

“[...] são muitos pacientes com um volume grande e você não consegue ver os pacientes direito e daí eu me sentia culpado, então eu passava o plantão oito da noite e eu não ia embora do PS, eu ficava lá resolvendo as coisas que eu não tinha conseguido resolver de dia. Teve várias noites no PSM que eu fui embora do plantão diurno onze da noite, meia noite, então eu literalmente saia, comia um negócio, e ia dormir ... e dormia as vezes cinco horas, seis [...] mas estressado, preocupado, com essa sensação meio que de insuficiência, sabe de: puxa, eu não estou conseguindo cuidar direito dos pacientes por causa do caos que é o PS! Então eu acho que é assim, a tensão do estágio fazia com que a qualidade do meu sono fosse pior [...] era muito frequente o sono diurno, que na minha opinião não repousa 
tanto, e o sono noturno estava atrelado ao estresse grande e o número de horas um pouco menor, entendeu?"

P12, masc.

“Quando você tem que dar os plantões noturnos é mais difícil ainda de você conseguir conciliar o estresse, a sobrecarga de trabalho, fisica, emocional e tudo isso porque te desregula sono, te desregula atividade social [...] aí você começa...você acorda vai pro hospital, não saí, nem vê a luz do dia.",

$$
\text { P10, fem. }
$$

Já sobre o estágio de Avaliação Pré-operatória/ Inter consultas, é marcante a ausência de plantões noturnos e a possibilidade de conciliar os horários de estágio com outras atividades.

"[...] com certeza do ponto de vista de carga horaria, do ponto de vista de cobrança, eu acho que é em disparada um dos estágios mais tranquilos assim, por que a gente realmente consegue ir embora no final da tarde pra casa sabe, tipo você consegue fazer mais atividade fisica, você consegue estudar mais, então assim é um mês mais tranquilo mesmo $[\ldots]$ "

P12, masc. 
“[...] a característica do estágio é que você não está responsável diretamente o tempo todo com o paciente internado, você mexe com paciente ambulatorial ou com pacientes que não estão aos seus cuidados [...] o vínculo que a gente tem é a distância, é um vínculo ambulatorial [...] te dá um pouco mais de tempo, ele não é tão exaustivo [...] não precisa passar o dia inteiro ali sob os seus cuidados."

$$
\text { P10, fem. }
$$

"Foi o meu maior período de atenção pessoal porque foi o período que eu consegui ir pra academia [...] conseguia ter contato com vida social...com minha família, com meu noivo com meus amigos... principalmente porque os horários eram muito mais adequados assim... eram mais, digamos assim, fisiológicos [...] o estágio começava às 7:00h e eu as vezes ficava até mais tarde, até umas 18:00 eu não me importava... as vezes estudava, preparava apresentação eu nunca me importei. Pelo menos no horário noturno nunca tinha plantão. Então era uma grande diferença e o plantão que a gente tinha no pronto-socorro [referindo-se aos finais de semana] também era diurno, então isso era muito bom."

P10, fem. 


\section{DISCUSSÃO}

\subsection{ORGANIZAÇÃO DO TRABALHO}

Quadros sindrômicos em médicos em treinamento são descritos há muito tempo. SMALL (1981) descreve um quadro composto por distúrbios cognitivos episódicos, raiva crônica, ceticismo, discórdia familiar, uso abusivo de drogas, depressão, ideação suicida e suicídio, correlacionando este quadro à privação do sono, excessiva carga de trabalho, responsabilidade profissional, mudanças frequentes das condições de trabalho e a competição entre os residentes.

Como discutido acima, estágios relacionados à atividades em pronto-socorros, unidades de terapia intensiva ou semi apresentam uma demanda de tempo elevada e uma sobrecarga emocional e mental frente a complexidade e gravidade dos pacientes. Aqueles relacionados a enfermarias e ambulatórios são percebidos com uma demanda de tempo menor, incluindo inclusive horários para estudo teórico e aulas, além de uma demanda psicológica mais branda.

Em hospital universitário de Santa Marina (Porto Alegre) foi levantado que 54\% dos residentes consideram a jornada de trabalho excessiva e $80 \%$ a consideram estressante. Considerando apenas os residentes de Clínica Médica, a jornada de trabalho foi considerada adequada pela totalidade dos residentes, porém $72,7 \%$ consideram a mesma estressante (VELHO et al., 2012).

No presente estudo é relatado uma carga horária elevada, muitas vezes pela atividade se estender para além do horário previsto devido intercorrências e visitas em enfermarias. $\mathrm{O}$ trabalho real nem sempre é o prescrito (DEJOURS, 2004), como muitas vezes aparece no discurso dos residentes. 
Temos, como exemplo, os dias com plantões da residência (Tabela 6 e 7), para os dois grupos, com mediana de tempo em atividades da residência (TAR) entre 12 e 13 horas diárias.

O foco deste trabalho não é a identificação de transtornos mentais embora diversos estudos mostrem uma alta incidência destes entre médicos residentes, geralmente associados a uma alta demanda em situações complexas. (BALDWIN; DODD; WRATE, 1997; CABANA et al., 2007; CARVALHO et al., 2013; ROCHA et al., 2010). Entre os fatores organizacionais associados a transtornos mentais, como a Síndrome de Burnout em médicos residentes, podemos citar: alta demanda de carga horária, falta de controle sobre os processos de trabalho (procedimentos e atendimentos), falta de reconhecimento, respeito e valorização pela instituição e percepção da importância do próprio trabalho (FABICHAK; DAS SILVAJUNIOR; MORRONE, 2014).

Ao analisarmos as representações do ciclo atividade /repouso dos médicos residentes (Figuras 2 a 8), ao compararmos o tempo despendido com as atividades práticas da residência (TAR) entre os estágios de Avaliação Pré-Operatória e o Pronto-socorro da Clínica Médica, fica evidente a grande carga horária prevista neste último (mediana de 7,1 e 12,5 horas, respectivamente - Tabela 6 e 7).

As atividades desenvolvidas pelo Grupo 2 são todas em regime de plantão, seja diurno ou noturno. O TAR se equipara ao do Grupo 1 ao avaliarmos dias nestes grupos com presença de plantões, mostrando que essa carga horária elevada é uma característica desse formato de trabalho. 


\subsection{REPOUSO}

Para um estado de vigília adequado um adulto dorme em média 7 a 8 horas em 24 horas, sendo que devido variações individuais, algumas pessoas podem necessitar de um maior ou menor número de horas de sono, sendo denominados dormidores curtos / pequenos dormidores ou dormidores longos / grandes dormidores (MORENO; FISCHER; ROTENBERG, 2003; POYARES et al., 2003; WEBB; FRIEL, 1970).

A Fundação Nacional do Sono dos E.U.A. (HIRSHKOWITZ et al., 2015) recomenda que jovens adultos (18 a 25 anos) e adultos (26 a 64 anos) tenham a duração de sono entre 7 a 9 horas, não sendo recomendável uma duração de sono menor do que 6 horas devido riscos para a saúde.

Os participantes do grupo 1 (Pré-op) apresentaram, em dias com atividade prática da residência, uma média do Tempo de Repouso Total (TRT) semelhante ao grupo 2 (PSM) durante os plantões noturnos, no entanto, o grupo 1 apresenta esta média locada no repouso noturno (TRN) enquanto o grupo 1 apresenta esta locação no repouso diurno (TRD).

Podemos notar, então, que o Tempo de Repouso Total (TRT), para os dias com atividades práticas na residência, é menor do que o recomendável ou muito próximo a este valor (HIRSHKOWITZ et al., 2015) para os dois grupos, fato exacerbado para o P9, que, na época do levantamento de dados, realizava outra atividade remunerada que não a residência e apresentou TRT de 5 horas.

Ao avaliarmos o tempo de repouso do grupo 2, no dia de folga, percebemos que este é menor do que nos dias de atividade prática na residência. Ao analisarmos as representações do 
ciclo atividade repouso (Figuras 7 e 8 ) percebemos que estas folgas apareceram com maior frequência após um plantão noturno, sendo este sono locado no período diurno.

Neste contexto, devemos levar em consideração alguns relatos mencionados nas entrevistas: a dificuldade de adormecer e sustentar o sono no período diurno; a sensação de que este sono não é repousante; a vontade de aproveitar o período de folga para outras atividades, como socialização com amigos, atividades de lazer, momentos com o parceiro ou mesmo atividades comuns como pagar contas.

Ou seja, percebemos uma restrição crônica de sono nos dois grupos de residentes, sendo mais exacerbada no grupo que realiza atividades práticas relacionadas à plantões noturnos, mesmo padrão encontrado no participante do grupo 1 que realizou outra atividade remunerada para complementação de renda.

Esta restrição, como listada em outros estudos, inclusive com acadêmicos de medicina, pode ser tanto por demanda de trabalho, exigências curriculares, responsabilidade familiar, estilo de vida e fatores pessoais.

No grupo 2 aparece ainda a fragmentação do repouso, resultando em uma quantidade e qualidade inadequada do mesmo, no caso, explicado por fatores ambientais que o interrompem. (MORENO; FISCHER; ROTENBERG, 2003; POYARES D RIZZO GNV, MINHOTO G, PINTO; JUNIOR LR ET AL., 2003; RIBEIRO; SILVA; OLIVEIRA, 2014).

Ao avaliarmos a percepção da qualidade do sono (Tabela 8) percebemos que, para ambos os grupos, a mediana das notas para o sono noturno é 6 e para o sono diurno é 4,5. Apesar da mesma mediana, devemos lembrar que o grupo 1 possui o sono principal locado no período noturno, como podemos verificar nas figuras 2 a 6 , sendo sua avaliação do repouso diurno predominantemente de cochilos. Notamos então, que esta avaliação é condizente com os 
relatos coletados, demonstrando uma percepção de sono "não repousante" ou "de baixa qualidade" durante o dia.

Importante salientar que o trabalho noturno pode levar a um pior desempenho de suas tarefas, uma maior chance de acidentes durante o desempenho de suas atividades e há um envelhecimento funcional precoce (MORENO; FISCHER; ROTENBERG, 2003).

Neste estudo há relatos de um pior desempenho em suas tarefas, incluindo incidentes que podem comprometer a segurança dos pacientes, em concordância com estudos que relatam a privação de sono de estudantes de medicina levando a deterioração mental, psicológica e física, diminuindo a capacidade de raciocínio, de retenção de informações e resolução de problemas, incluindo a interpretação de exames e erros de prescrição médica (CHAGAS CARDOSO et al., 2009; PIKOVSKY et al., 2013; RIBEIRO; SILVA; OLIVEIRA, 2014; ZERAATCHI et al., 2013).

Em inquérito realizado no Reino Unido (MCCLELLAND et al., 2017) com residentes em Anestesia mostra que a fadiga resultante deste treinamento, mesmo com a redução da jornada de 56 para 48 horas semanas, interfere no bem estar psicológico, saúde física e relacionamentos pessoais desses residentes, sendo esses fatores mais problemáticos no turno da noite.

\subsection{ESTUDO TEÓRICO DURANTE PERÍODO DE FOLGA}

Apesar da residência ser caracterizada como um período de plena imersão na atividade profissional (NOGUEIRA-MARTINS, 2010), há a necessidade de estudo teórico para complementação da parte prática. 
No grupo que estava no estágio de Avaliação Pré-Operatória, a média diária de estudo teórico nos dias de atividade prática foram de $02 \mathrm{~h} 11 \mathrm{~min}$, muito semelhante à média de estudo em dias de folga, de $02 \mathrm{~h} 43 \mathrm{~min}$.

Já no grupo do Pronto-socorro de Clínica Médica não houve mediana para este valor. Esta diferença decorre, de acordo com a parte qualitativa deste estudo, devido a diferença de carga horária destes estágios, sendo que, devido o pouco tempo livre do grupo 2 , há a prioridade de realização de outras atividades sociais neste período.

RENA (2012) discute se a atual organização da residência médica, com a carga horária atual supre a necessidade de formação dos médicos brasileiros, questionando especificamente se o período de 2 anos para os programas que são requisitos para outras especialidades, como no caso da Residência em Clínica Médica ou Cirurgia, são adequados.

O aumento no tempo de formação permitiria uma melhor distribuição das atividades, provavelmente diminuindo a carga horária real de trabalho diária permitindo, inclusive, o aumento da carga de estudo teórico. Por outro lado, interferiria no planejamento pessoal dos residentes, que teriam que adequar seu planejamento pessoal e financeiro para um período maior de formação.

Apesar das dificuldades de assimilação do conteúdo programado no tempo propostos, gerando uma carga horária extensa em alguns estágios e um pouco tempo para estudo teórico, a residência médica aparece como um período de grande amadurecimento e aprendizagem profissional, assim como levantado por outros autores (BOTTI; REGO, 2010; NOGUEIRAMARTINS, 2010; VEASEY et al., 2002). 


\subsection{ATIVIDADES REMUNERADAS NÃO VINCULADAS À RESIDÊNCIA E} TEMPO PARA LAZER

Considerando o tempo com atividades práticas da residência (TAR) e tempo para lazer (TL), o grupo 1, nos dias de plantões pela residência apresenta distribuição semelhante à do grupo 2. No entanto, apresenta um TAR inferior ao do grupo 2 para dias sem plantões, o que permite distribuir o tempo restante em tempo de estudo (TET) e realizar atividades remuneradas extra residência (representado pelo participante 9).

Todos os participantes relataram realizar atividades remuneradas não vinculadas à residência durante sua formação. Múltiplos fatores levam a este quadro: estratégias para manejo do tempo que aumentam seu custo de vida (como moradia próximo à instituição de ensino, alimentação em restaurantes, contratação de diaristas para tarefas domésticas), necessidade / vontade de independência financeira e o valor atual da bolsa de residência (aproximadamente $1 / 7$ do valor pago pelo mercado se estes profissionais trabalhassem nestes períodos).

Os relacionamentos pessoais também são afetados durante a residência, tanto pelo pouco tempo disponível para investir em relações sociais fora do ambiente de trabalho quanto pelo cansaço ou necessidade de desenvolver outras atividades remuneradas ou estudo teórico em seu tempo livre, fato também exacerbado nos estágios com plantões noturnos.

Trabalhadores em turnos, principalmente os que exercem atividades no turno da noite, relacionam-se a um cotidiano diferente do restante da comunidade, os que o tornam propenso a enfrentar dificuldades de convivência com amigos e familiares (MORENO; FISCHER; ROTENBERG, 2003; RIBEIRO; SILVA; OLIVEIRA, 2014). 
No caso dos residentes, essa dificuldade é descrita em períodos sem plantões previstos, devido a quantidade de horas e complexidade dos estágios, com agravamento nos períodos em que há trabalho em plantões noturnos, sejam os previstos pela residência quanto aqueles realizados para complementação de renda.

ASAIAG et al. (2010) conclui que os residentes percebem que sua qualidade de vida é pior durante a residência do que em sua vida em geral, traçando uma proporcionalidade direta entre carga horária semanal e nível de sonolência diurna, dados em concordância com as entrevistas deste estudo.

Estudos sobre trabalhos em turnos mostram que o gênero tem influência na tolerância a estes trabalhos devido comportamentos sociais e não biológicos, sendo mais complexo para as mulheres devido as atividades tradicionais domésticas e à família, diminuindo seu tempo para repouso diurno e lazer (MORENO; FISCHER; ROTENBERG, 2003; NACHREINER, 1998; ROTENBERG et al., 2001).

Neste estudo as entrevistas não mostraram diferenças entre gênero fato que pode ser explicado pela aparente uniformização dos comportamentos sociais nesta fase: o auxílio das atividades domésticas por diaristas, a dificuldade de manter relacionamentos afetivos, a opção por adiar o momento da paternidade/maternidade, dado em conformidade com o estudo de ASAIAG et al. (2010) que não encontraram diferenças entre gêneros ao avaliar a qualidade de vida de médicos residentes. 


\subsection{SUPORTE SOCIAL, PLANEJAMENTO FAMILIAR E ESTRATÉGias}

\section{INSTITUCIONAIS DE APOIO}

O suporte social, durante a fase de residência, é importante para prevenção de transtornos mentais, em especial o burnout, sendo tanto apoio familiar importante quanto o apoio dos supervisores dos programas e estágios, das equipes que participam das atividades (internos, enfermagem, outros assistentes) e dos outros médicos em treinamento (ASSUNCAO et al., 2013; MIKKOLA; SUUTALA; PARVIAINEN, 2018).

No discurso apresentado pelos residentes há uma dificuldade, devido ao pouco tempo livre, em manter relacionamentos próximos com familiares e amigos. Mesmo assim, estes são caracterizados como pilares de suporte social durante os discursos, tendo um papel de destaque os relacionamentos de amizade e apoio entre os próprios residentes. É relatado também uma dificuldade em conciliar relacionamentos amorosos nesta fase mas, quando estes ocorrem, fica caracterizado um suporte social importante.

Nos programas que são requisitos para outras especialidades, como a Clínica Médica, muitos residentes elegem como prioridade a preparação para o concurso de egresso na próxima residência (RENA, 2012). Neste estudo os residentes optaram por adiar o momento da maternidade / paternidade para focar no estudo da residência atual, preparação para a prova de título da especialidade ou para a prova do próximo concurso de residência.

A esposa de um dos entrevistados, que é residente de Pediatria, está grávida. No relato deste participante fica claro as dificuldades encontradas pelo casal frente a gravidez neste período como o aumento da carga horária em outras atividades remuneradas do entrevistado e 
a necessidade de apoio à sua esposa por outros colegas residentes e supervisores para que as atividades do programa sejam desempenhadas.

Assim como no relato, MCCARTNEY (2016) discute as dificuldades de médicas no Reino Unido aderirem a contratos de trabalho de tempo integral, considerando as redes de apoio para a maternidade e o fato que nesta profissão um contrato de trabalho de 35-40 horas semanais é de meio período.

Na tentativa de fornecer suporte ao residente, a Residência de Clínica Médica implantou uma estratégia de apoio denominada "Programa de Tutoria". Este programa é caracterizado por reuniões mensais nas quais 1 tutor acompanha um grupo de 8 residentes durante os dois anos de residência. Este programa é bem avaliado pelos residentes pois abre a possibilidade de diálogo, tanto entre os residentes quanto com seus supervisores, além de fornecer apoio social e, por vezes, psicológico.

\subsection{FORMAÇÃO MÉDICA}

Durante a residência médica há diversos profissionais mais experientes que orientam, auxiliam e avaliam o médico residente. Este vêm recebendo diferentes denominações, entre as quais preceptor, supervisor, tutor e mentor (BOTTI; REGO, 2007). Como a denominação corrente durante as entrevistas foi "supervisor", usaremos este termo para o médico assistente que acompanha as atividades do residente, tem a incumbência de orientá-lo e avaliá-lo durante o período de estágio. 
Segundo FERRI; GOMES (2015) há uma grande preocupação dos médicos em formação com a avaliação de seus supervisores, a sensação de que qualquer comportamento ou atitude é avaliado por estes. Esta percepção aparece de forma implícita em vários discursos neste estudo, sendo fator de preocupação tanto a avaliação dos supervisores quanto de outros colegas residentes. Pensar no erro torna-se uma prática constante durante as atividades (FERRI; GOMES, 2015), o que aumenta a tensão e a ansiedade no cotidiano destes profissionais.

A complexidade e gravidade dos pacientes, o manejo de situações delicadas, como a terminalidade da vida e a situação de impotência frente a falta de recursos são caracterizados como fatores de sobrecarga psicológica, que são somados a sobrecarga física devido a quantidade de horas na jornada (FERRI; GOMES, 2015; NOGUEIRA-MARTINS, 2010; NOGUEIRA-MARTINS; JORGE, 1998), principalmente nos estágios de atividades em prontos-socorros e de unidades de terapia intensivas (ou semi). Nestes estágios é relatado a necessidade de uma supervisão mais presente e humana para auxiliar a lidar com estas situações.

Estas mesmas dificuldades aparecem em estudos com médicos já formados, durante o desempenho de suas atividades, como intensivistas, anestesistas, pediatras e outras especialidades (ASSUNÇÃO; LIMA, 2010; NOGUEIRA-MARTINS, 2003; STANISCIA et al., 2011).

Apesar de contraditório, os próprios residentes reconhecem estes fatores de sobrecarga psicológica como necessários para a formação médica adequada. Nos discursos, por exemplo, 
o Pronto-Socorro aparece como um estágio de alta sobrecarga, porém ligado há um período de responsabilidades na qual o residente sente-se útil e recompensado por ela.

COUSINS (1981), avaliando a formação médica de vários Estados dos E.U.A., compara a Residência Médica à um "ritual de passagem", um "teste de resistência” pelo qual é esperado que o médico recém-formado passe, cenário idêntico ao apresentado neste estudo.

Segundo HEDDLE; HEUDEBERT (2007) é esperado do residente que absorva conhecimentos e técnicas específicas e que consiga responder, com eles, aos diversos pacientes em diferentes contextos.

O modelo relatado pelos residentes é estruturado em estágios fixos e não integrados que, com o desenvolvimento de novas técnicas e tratamentos, aumentam gradativamente a quantidade de habilidades e conhecimento que devem ser adquiridos. Há necessidade de repensar o ensino de modo a otimizar o aprendizado destes estudantes integrando as disciplinas e facilitando o aprendizado (HEDDLE; HEUDEBERT, 2007).

\subsection{LIMITAÇÕES E PONTOS FORTES DO ESTUDO}

Este estudo foi realizado com uma população de características próprias: médicos residentes, de clínica médica, sendo realizada as duas fases do estudo com residentes do $2^{\circ}$ ano.

Trata-se de hospital escola, de grande porte, que atende unicamente pacientes do Sistema Único de Saúde e cuja entrada no concurso de residência ocorre após uma concorrência 
elevada. Desta maneira há que se guardar as devidas proporções na generalização dos dados para outras populações de médicos residentes.

Devido limitação de tempo em campo e a adesão dos participantes, durante a $2^{\circ}$ fase do estudo, houveram 5 residentes no $1^{\circ}$ grupo e 2 residentes no $2^{\circ}$ grupo. Desta maneira, por não serem os mesmos residentes comparados em diferentes estágios, há que se considerar as variações individuais durante as análises.

Como os dados de actimetria foram excluídos do estudo, as representações do ciclo repouso /atividade foram realizadas utilizando-se os dados dos protocolos de atividades diárias, instrumento desenhado para validação dos dados da actigrafia e que não possui dados de sono tão exatos quanto os registrados pelo actígrafo.

Para este estudo foram utilizadas metodologias validadas e realiza uma abordagem mista apresentando dimensões diferentes de um mesmo objeto, sendo uma abordagem quantitativa (numérica) e uma abordagem em profundidade com as entrevistas.

A pesquisa foi realizada com médicos de um hospital que é serviço de referência nacional e internacional, sendo esta uma população de difícil acesso. 


\section{CONCLUSÕES}

A Residência Médica é um período da formação marcado por uma imersão na especialidade escolhida, através de atividades práticas que visam o desenvolvimento de capacidades técnicas e o amadurecimento profissional.

Os residentes de Clínica Médica vivenciam um período de aprendizado intenso e que demanda uma carga horária de atividades elevadas e complexas. Estas podem levar o residente há uma restrição de sono crônica, complicada com períodos de plantões noturnos e em fins de semana, previstos pela residência ou por outras atividades remuneradas não vinculadas a residência.

Trata-se de uma fase em que o médico, em início de carreira, busca independência financeira, de tal forma que todos os residentes participantes do estudo relataram desenvolver alguma atividade remunerada não vinculada a residência, em algum período durante esta, para complementação de renda.

Estas atividades, via de regra, ocorrem em trabalhos informais, autônomos ou por empresas jurídicas dos próprios residentes, ocorrendo em estágios em que a carga horária possibilita o acúmulo de horas, mas diminuindo desta maneira o tempo previsto para repouso, estudo, lazer ou outras atividades sociais.

Há diversas estratégias adotadas para gestão do tempo, muitas delas, apesar de diminuir o tempo com determinadas atividades, encarecem o custo de vida. Entre elas podemos perceber:

- configuração de moradias próximas ao hospital;

- auxílio das atividades domésticas por empregadas/diaristas;

- a utilização dos restaurantes do hospital para a maioria das refeições;

- o adiamento da maternidade/paternidade para após a conclusão da residência; 
- apoio social centrado no convívio com outros colegas residentes e supervisores do programa;

- otimização do tempo disponível para atividades de lazer, relacionamentos familiares e afetivos, por vezes em detrimento do tempo para repouso.

Ao comparar o grupo que estava no Pronto-socorro de Clínica Médica com o grupo do estágio de Avaliação Pré-Operatória, percebemos a maior demanda do primeiro em relação a horas de atividades práticas, reduzindo o tempo de repouso, tempo de estudo teórico e de atividades para lazer. Trata-se de um estágio em que, devido a disponibilidade de tempo, não é comum a prática de outras atividades remuneradas.

São relatados uma piora do convívio social e familiar durante os períodos de plantões noturnos, além de uma maior restrição do período de sono, comparados a períodos sem plantões, e o deslocamento de parte do repouso para o período diurno, dificultando o repouso e piorando a qualidade do sono, o que ocorre tanto nos plantões previstos pela residência, mesmo com o repouso pós-plantão sendo respeitado, quanto na execução de outras atividades remuneradas.

A duração de um mês dos estágios é apontada pelos residentes como um fator positivo em estágios de alta demanda de carga horária ou psicológica, assim como estratégias institucionais de apoio social, como o programa de tutoria desenvolvido pela Clínica Médica, que facilita a comunicação entre os residentes e os supervisores. 


\section{CONSIDERAÇÕES FINAIS}

Devido às políticas públicas das últimas décadas há um elevado número de médicos residentes no Brasil. Apesar deste aumento não há uma rede estruturada em âmbito federal para monitorar a saúde destes jovens médicos e verificar as condições de trabalho destes, por vezes, consideradas como uma organização do trabalho tóxica.

Há a necessidade de realizar pesquisas sobre organização temporal e organização do trabalho com os gestores e supervisores envolvidos nestes programas de residência.

Apesar das melhorias ocorridas nos últimos anos, como a previsão de folga pós-plantão para os residentes, há várias oportunidades que podem ser exploradas para melhoria da qualidade de vida neste período:

- redução da carga horária de estágios específicos, como os de Prontos-socorros e Unidades de Terapia Intensiva, onde há uma sobrecarga de trabalho física e psicológica;

- valorização e aprimoramento de iniciativas institucionais para suporte ao residente, como o "Programas de tutoria";

- implantação de programas institucionais que viabilizem a inserção de médicas residentes gestantes nos cursos;

- implantação de estratégias para capacitações de supervisores mais centrados no residente como indivíduo;

-implantação de um programa de monitorização da saúde dos médico residente;

- fiscalização da realização da jornada prevista pela legislação vigente;

- aumento do tempo para descanso no pós-plantão noturno (legislação trabalhista preconiza período mínimo de descanso de 11 horas seguidas entre dois períodos diários de trabalho consecutivo); 
- adoção de rodízio entre as atividades de estágios com alta demanda física ou mental e estágios com baixa demanda;

- reestruturação do modelo de ensino da residência, buscando otimização do aprendizado e integração entre as áreas de ensino; 


\section{REFERÊNCIAS}

AKERSTEDT, T.; GILLBERG, M. Displacement of the sleep period and sleep deprivation. Implications for shift work. Human neurobiology, n. 3, p. 163-171, 1982.

ALMEIDA, M. J. DE. Educação médica e saúde: limites e possibilidades das propostas de mudança. Interface - Comunicação, Saúde, Educação, v. 2, n. 2, p. 214-215, fev. 1998.

ALTOÉ, S. M. L. et al. Work-life Balance na ótica de contadores paranaenses. RIGC, v. 12, n. 24, p. 1-20, 2014.

AMBUlATORY MONITORING. Action-W. Ardsley, NY USA:Ambulatory Monitoring, Inc. (800) 341-0066, fax: (914)693-6604, 1996.

AMBUlatory MONITORING. Act Millennium. Ardsley, NY USA: Ambulatory Monitoring, Inc. (800) 341-0066, fax: (914)693-6604, 2003.

AMORETTI, R. A educação médica diante das necessidades sociais em saúde. Revista Brasileira de Educação Médica, v. 29, n. 2, p. 136-146, 2005.

ANDRADE, M. C. P. Work-Life balance: condições de trabalho facilitadoras da integração do papel profissional e familiar. Exedra, v. número esp, p. 41-54, 2011.

ASAIAG, P. E. et al. Avaliação da qualidade de vida, sonolência diurna e burnout em Médicos Residentes. Revista Brasileira de Educação Médica, v. 34, n. 3, p. 422-429, set. 2010.

ASSOCIAÇÃO BRASILEIRA DE EDUCAÇÃO MÉDICA. Origem e evolução do internato. In: ASSOCIAÇÃO BRASILEIRA DE EDUCAÇÃO MÉDICA. O Internato nas escolas médicas brasileiras. RIo de Janeiro: Associação Brasileira de Educação Médica, 1982. p. 7- 
13.

ASSUNCAO, A. A. et al. Working conditions and common mental disorders in physicians in Brazil. Occupational Medicine, v. 63, n. 3, p. 234-237, 1 abr. 2013.

ASSUNÇÃO, A. A.; LIMA, F. P. A. Aproximações da ergonomia ao estudo das exigências afetivas da tarefa. In: GLINA, D. M. R.; ROCHA, L. E. (Eds.). Saúde Mental no Trabalho: da teoria à prática. $1^{\circ}$ ed. São Paulo: Roca, 2010. p. 210-228.

BAFFA, A. M. Internato Médico: Desafios da Avaliação da Aprendizagem em Serviço. Dissertação (mestrado) - Pontifícia Universidade Católica de Campinas, Centro de Ciências Sociais Aplicadas, Pós-Graduação em Educação, 2008.

BALDWIN, P. J.; DODD, M.; WRATE, R. W. Young doctors' health -I. How do working conditions affect attitudes, health and performance? Social science \& medicine, v. 45, n. 1, p. 35-40, 1997.

BERNARD, J. Esperanças e Sabedoria da Medicina. Tradução de Roberto Leal Ferreira. São Paulo: Unesp, 1998.

BORGES, F. N. DA S. Repercussões do trabalho em turnos noturnos de 12 horas no sono e bem estar em auxiliares de enfermagem e enfermeiros. [s.l.] Universidade de São Paulo, 2002.

BOTTI, S. H. DE O.; REGO, S. Processo ensino-aprendizagem na residência médica. Revista Brasileira de Educação Médica, v. 34, n. 1, p. 132-140, 2010.

BRASIL. Resolução $\mathbf{n}^{\mathbf{0} 466}$, de 12 de dezembro de 2012. Disponível em: <http://bvsms.saude.gov.br/bvs/saudelegis/cns/2013/res0466_12_12_2012.html\%5Cnhttp://co 
nselho.saude.gov.br/resolucoes/2012/Reso466.pdf>.

BRASIL. PRESIDÊNCIA DA REPÚBLICA. Decreto $\mathrm{n}^{\circ} 80.281$ de 5 de setembro de 1977 . Regulamenta a Residência Médica, cria a Comissão Nacional de Residência Médica e dá outras providências. Brasília, D.O.U. de 05/09/1977.

BRASIL. PRESIDÊNCIA DA REPÚBLICA. Lei 6932 de 7 de julho de 1981. Dispõe sobre a atividade do médico residente e dá outras providências. Brasília, D.O.U. de 09/07/1981.

CABANA, M. C. F. D. L. et al. Transtornos mentais comuns em médicos e seu cotidiano de trabalho. Jornal Brasileiro de Psiquiatria, v. 56, n. 1, p. 33-40, 2007.

CARVALHO, C. N. et al. Prevalência e fatores associados aos transtornos mentais comuns em residentes médicos e da área multiprofissional. Jornal Brasileiro de Psiquiatria, v. 62, n. 1, p. 38-45, 2013.

CHAGAS CARDOSO, H. et al. Avaliação da qualidade do sono em estudantes de Medicina. Revista Brasileira de Educação Médica, v. 33, n. 3, p. 349-355, 2009.

CHAVES, H. L. et al. Vagas para Residência Médica no Brasil: Onde Estão e o que É Avaliado. Revista Brasileira de Educação Médica, v. 37, n. 4, p. 557-565, 2013.

CHAVES, I. T. DA S.; GROSSEMAN, S. O Internato médico e suas perspectivas: estudo de caso com educadores e educandos. Revista Brasileira de Educação Médica, v. 31, n. 3, p. 212-222, 2007.

CLARK, S. C. Work/Family Border Theory: A New Theory of Work/Family Balance. Human Relations, v. 53, n. 6, p. 747-770, 2000. 
CLEVER, L. H. A Saúde do Médico. In: BEESON, P.; MCDERMOTT, W. (Eds.). Cecil Loeb: Tratado de Medicina. Rio de Janeiro: Guanabara Koogan, 1990.

COMISSÃO NACIONAL DE RESIDÊNCIA MÉDICA. Resolução CNRM N4 de 16.06.2011 - Dispõe sobre o estabelecimento e condições de descanso obrigatório para o médico residente que tenha cumprudido plantão noturno. Brasil, 2011.

CONSELHO FEDERAL DE MEDICINA. Residência Médica. Disponível em: $<$ http://portal.cfm.org.br/index.php?option $=$ com_content\&id=88\&Itemid $=47>$. Acesso em: 5 jan. 2017.

COREME. Comissão Nacional de Residência Médica - Edital Residência Médica 2017. Faculdade de Medicina da USP, 2016.

COUSINS, N. Internship: Preparation or Hazing? JAMA: The Journal of the American Medical Association, v. 245, n. 4, p. 377, 23 jan. 1981.

CROUTER, A. C. et al. Linking parents' work pressure and adolescents' well-being: insights into dynamics in dual-earner families. Developmental psychology, v. 35, n. 6, p. 1453-1461, 1999.

DARCY, C. et al. Work-life balance: One size fits all? An exploratory analysis of the differential effects of career stage. European Management Journal, v. 30, n. 2, p. 111-120, 2012.

DAVIES, N. The work-life balance. Nursing standard (Royal College of Nursing (Great Britain): 1987), v. 29, n. 2, p. 63, 2014.

PELLEGRINI, C. F. DE S.; CALAIS, S. L.; SALGADO, M. H. Habilidades sociais e 
administração de tempo no manejo do estresse. Arquivos Brasileiros de Psicologia, v. 64, n. 3, p. 110-129, 2012.

DEJOURS, C. Subjetividade, trabalho e ação. Revista Produção, v. 14, n. 3, p. 27-34, 2004.

DICKINSON, D. L.; MCELROY, T. Sleep restriction and circadian effects on social decisions. European Economic Review, v. 97, p. 57-71, 2017.

EDWARDS, J. R.; ROTHBARD, N. P. Mechanisms linking work and family: Clarifying the relationship between work and family constructs. Academy of Management Review, v. 25, n. 1, p. 178-199, 2000.

EDWARDS, M. E. Uncertainty and the rise of the work-family dilemma. Journal of Marriage and Family, v. 63, n. 1, p. 183-196, 2001.

FABICHAK, C.; DA SILVA-JUNIOR, J. S.; MORRONE, L. C. Síndrome de burnout em médicos residentes e preditores organizacionais do trabalho. Revista Brasileira de Medicina do Trabalho, v. 12, n. 2, p. 79-84, 2014.

FERREIRA, V. S. Artes e manhas da entrevista compreensiva. Saude e Sociedade, v. 23, n. 3, p. 118-130, 2014.

FERRI, P. A.; GOMES, R. DA S. Formação situada ou situações do formar: Internato Médico em questão. Revista Brasileira de Educação Médica, v. 39, n. 2, p. 252-260, 2015.

FILARDI, M. et al. Actigraphic assessment of sleep/wake behavior in central disorders of hypersomnolence. Sleep Medicine, v. 16, n. 1, p. 126-130, 2015.

FISCHER, F. M. Método de avaliação do ritmo de trabalho e repouso entre condutores 
de veículos. In:Primeiro Congresso Brasileiro de Segurança de Tráfego, São Paulo, 1986.

FISCHER, F. M. Condições de trabalho e de vida em trabalhadores de setor petroquímico. [s.1.] Universidade de São Paulo, 1990.

FISCHER, F. M.; MORENO, C. R. C.; ROTENBERG, L. Trabalho em turnos e noturno: impactos sobre o bem-estar e saúde dos trabalhadores. Possíveis intervenções. In: MENDES, R. Patologia do Trabalho. $3^{\circ}$ ed. São Paulo: Atheneu, 2013. Cap. 25.

FRONE, M. R. Interpersonal conflict at work and psychological outcomes: testing a model among young workers. Journal of occupational health psychology, v. 5, n. 2, p. 246-255, 2000.

FRONE, M. R.; MARKEL, K. S.; YARDLEY, J. K. Developing and Testing an Integrative Model of the Work - Family Interface. Journal of Vocational Behavior, v. 50, n. 50, p. 145$167,1997$.

GASPAR, S.; MORENO, C.; MENNA-BARRETO, L. Os plantões médicos, o sono e a ritmicidade biológica. Revista da Associação Médica Brasileira, v. 44, n. 3, p. 239-245, 1984.

GOLDSTEIN-PIEKARSKI, A. N. et al. Sleep deprivation impairs the human central and peripheral nervous system discrimination of social threat. The Journal of Neuroscience, v. 35, n. 28, p. 10135-10145, 2015.

HIRSHKOWITZ, M. et al. National sleep foundation's sleep time duration recommendations: Methodology and results summary. Sleep Health, v. 1, n. 1, p. 40-43, 2015. 
HUDDLE, T.S.; HEUDEBERT, G.R. Taking Apart the Art: The Risk of Anatomizing Clinical Competence. Acad Med., v. 82, p. 536-541, 2007.

INSTITUTO BRASILIERO DE GEOGRAFICA E ESTATÍSTICA. Projeção Populacional. Disponível em: <https://www.ibge.gov.br/apps/populacao/projecao/>, acessado em $01 / 06 / 2018$.

KHALLASH, S.; KRUSE, M. The future of work and work-life balance 2025. Futures, v. 44, n. 7, p. 678-686, 2012.

KNAUTH, P. et al. Time-budget studies of policemen in weekly or swiftly rotating shift systems. Applied Ergonomics, v. 14, n. 4, p. 247-252, 1983.

LEMKE, M. R. et al. [Motor behavior in depression: applications and limitations of actigraphic analyses]. Aktivitat und Depression--Moglichkeiten und Grenzen aktigraphischer Verhaltensanalysen., v. 28, n. 5, p. 219-225, 2001.

LEWANDOWSKI, C. M. The Industrial-Organizational Psychologist. The IndustrialOrganizational Psychologist, v. 50, n. 1, 2012.

LOURENÇÃO, L. G.; SOLER, Z. A. S. G.; MOSCARDINI, A. C. Saúde e qualidade de vida de Médicos Residentes. Rev Assoc Med Bras, v. 53, n. 1, p. 81-91, 2010.

MACHADO, M. H. Os médicos no Brasil: um retrato da realidade. São Paulo: Fiocruz, 1997.

MAHER, C. A. Time management training for school psychologists. Professional Psychology, v. 12, n. 5, p. 613-620, 1981. 
MANSUKHANI, M. P. et al. Sleep deprivation in resident physicians, work hour limitations, and related outcomes: A systematic review of the literature. Postgraduate Medicine, v. 124, n. 4, p. 241-249, 2012.

MAXQDA. MAXQDA - Software für qualitative Datenanalyse. Disponível em: $<$ http://www.maxqda.de/>.

MCCALL, T. B. The Impact of Long Working Hours on Resident Physicians. New England Journal of Medicine, v. 318, n. 12, p. 775-778, 24 mar. 1988.

MCCARTNEY, M. Margaret McCartney: A sexist contract for junior doctors. BMJ, v. 1943, n. April, p. i1943, 5 abr. 2016.

MCCLELLAND, L. et al. A national survey of the effects of fatigue on trainees in anaesthesia in the UK. Anaesthesia, v. 72, n. 9, p. 1069-1077, set. 2017.

MELLO, S. L. Pensando o cotidiano em ciências sociais: identidade e trabalho. Cadernos CERU, v. 5, p. 23-31, 1994.

MICROSOFT CORPORATION. Microsoft Excel, 2013.

MIKKOLA, L.; SUUTALA, E.; PARVIAINEN, H. Social support in the workplace for physicians in specialization training. Medical Education Online, v. 23, n. 1, p. 1435114, 2018.

MINISTÉRIO DA EDUCAÇÃO. Residência Médica. Disponível em: $<$ http://portal.mec.gov.br/residencias-em-saude/residencia-medica?id=12263>. Acesso em: 5 jan. 2017a. 
MINISTÉRIO DA EDUCAÇÃO. Legislação Específica. Disponível em: $<$ http://portal.mec.gov.br/index.php?option=com_content\&view=article\&id=12703:legislacao -especifica-e-atas\&catid=247:residencia-medica $>$. Acesso em: 16 jan. $2017 \mathrm{~b}$.

MONK, T. H. A visual analogue scale technique to measure global vigor and affect. Psychiatry Research, v. 27, n. 1, p. 89-99, 1989.

MORENO, C. R. D. C.; FISCHER, F. M.; ROTENBERG, L. A saúde do trabalhador na sociedade 24 horas. São Paulo em Perspectiva, v. 17, n. 1, p. 34-46, 2003.

MOTA, M. C. et al. Dietary Patterns, Metabolic Markers and Subjective Sleep Measures in Resident Physicians. Chronobiology International, v. 30, n. 8, p. 1032-1041, 2013.

MUNIR, F. et al. Mediating the effects of work-life conflict between transformational leadership and health-care workers' job satisfaction and psychological wellbeing. Journal of Nursing Management, v. 20, n. 4, p. 512-521, 2012.

NACHREINER, F. Individual and social determinants of shiftwork tolerance. Scandinavian Journal of Work, Environment and Health, v. 24, n. 3, p. 35-42,1998.

NOGUEIRA-MARTINS, L. A. Saúde Mental dos Profissionais de Saúde. Rev. Bras. Med. Trab. Belo Horizonte, v. 1, n. 1, p. 56-68, 2003.

NOGUEIRA-MARTINS, L. A. Qualidade de Vida dos Médicos Residentes: Revisão de Estudos Brasileiros. Cadernos ABEM, v. 6, p. 12-18, 2010.

NOGUEIRA-MARTINS, L.; JORGE, M. Natureza e magnitude do estresse na Residência Médica. Rev Ass Med Brasil, v. 44, n. 1, p. 28-34, 1998. 
NUNES, C.; SANTANA, M. A. Clínica Médica. In: NUNES, C.; SANTANA, M. A. (Eds.). Residência Médica. $2^{\circ}$ ed. Editora Sanar, 2016. p. 271-80.

OLIVEIRA, D. C. DE. Análise de conteúdo temático-cateorial: uma proposta de sistematização. Rev. enferm., v. 16, n. 4, p. 569-576, 2008.

OSWALD, V.; EICHENBERG, F. No Reino Unido e na Suécia, médicos precisam servir no setor público. Disponível em: $<$ https://oglobo.globo.com/brasil/no-reino-unido-na-sueciamedicos-precisam-servir-no-setor-publico-8979622>. Acesso em: 5 fev. 2017.

PIKOVSKY, O. et al. The impact of sleep deprivation on sleepiness, risk factors and professional performance in medical residents. Israel Medical Association Journal, v. 15, n. 12, p. 739-744, 2013.

PONTES, O. D. DE A.; SOUSA-MUÑOZ, R. L. DE. O internato médico no novo currículo de uma universidade pública: a apreciação do estudante. Revista Brasileira de Educação Médica, v. 38, n. 4, p. 519-531, 2014.

PORTELA, L. F.; ROTENBERG, L.; WAISSMANN, W. Self-Reported Health and Sleep Complaints Among Nursing Personnel Working Under $12 \mathrm{~h}$ Night and Day Shifts. Chronobiology International, v. 21, n. 6, p. 859-870, 2004.

POYARES, D. et al. I Consenso Brasileiro de Insonia. Hypnos: rev sono, v. 4, n. (Supl 2), p. $5-39,2003$.

PURIM, K. S. M. et al. Privação do sono e sonolência excessiva em médicos residentes e estudantes de medicina. v. 43, n. 6, p. 438-444, 2016.

RENA, C. DE L. O papel da residência médica. Revista Médica de Minas Gerais, v. 22, n. 
4, p. 430-432, 2012.

RIBEIRO, C. R. F.; SILVA, Y. M. G. P. DA; OLIVEIRA, S. M. C. DE. O impacto da qualidade do sono na formação médica. Rev Soc Bras Clin Med, v. 12, n. 1, p. 8-14, 2014.

RICHARDSON, R. J. Questionário. In: Pesquisa Social - Métodos e Técnicas. $3^{\circ}$ ed. São Paulo: Editora Atlas, 1999. p. 189-205.

ROCHA, S. V. et al. Prevalência de transtornos mentais comuns entre residentes em áreas urbanas de Feira de Santana, Bahia. Revista Brasileira de Epidemiologia, v. 13, n. 4, p. 630-640, 2010.

RODRIGUES, V. F. Principais impactos do trabalho em turnos: estudo de caso de uma sonda de perfuração marítima. Revista da Universidade de Alfenas, v. 4, p. 199-207, 1998.

ROTENBERG, L. et al. Gênero e trabalho noturno: sono, cotidiano e vivências de quem troca a noite pelo dia. Cad. Saúde Pública, v. 17, n. 3, p. 639-649, 2001.

SANBORN, G. Work-Life Balance. Jom, v. 65, n. 6, p. 675, 2013.

ShEFFER, M.; BIANCARELli, A.; CASSENOTE, A. Demografia Médica no Brasil 2015. São Paulo: Departamento de Medicina Preventiva da USP; Conselho Regional de Medicina do Estado de São Paulo; Conselho Federal de Medicina, 2015.

SCHEFFER, M. et al. Demografia Médica no Brasil 2018. São Paulo: Departamento de Medicina Preventiva da USP; Conselho Regional de Medicina do Estado de São Paulo; Conselho Federal de Medicina, 2018.

SIMON, E. B. et al. Losing Neutrality: The Neural Basis of Impaired Emotional Control 
without Sleep. Journal of Neuroscience, v. 35, n. 38, p. 13194-13205, 2015.

SMALL, G. W. House officer stress syndrome. Psychosomatics, v. 22, n. 10, p. 869-864, 1981.

STANISCIA, A. C. M. et al. Dificuldades emocionais vivenciadas pelos médicos intensivistas da unidade de terapia - adulto de um hospital geral privado. Rev SBPH, v. 14, n. 1, 2011.

TEICHER, M. H. Actigraphy and motion analysis: new tools for psychiatry. Harvard review of psychiatry, v. 3, n. 1, p. 18-35, 1995.

TURATO, E. R. Métodos qualitativos e quantitativos na área da saúde: Definições, diferenças e seus objetos de pesquisa. Revista de Saude Publica, v. 39, n. 3, p. 507-514, 2005.

UENO, H. M.; NATAL, D. Fundamentos de epidemiologia. In: ROCHA, A. M.; CHESTER, L. G. C.; RIBEIRO, H. Saúde Pública: bases conceituais. $2^{\circ}$ ed. São Paulo: Editora Atheneu, 2013. Cap 2

VEASEY, S. et al. Sleep loss and fatigue in residency training: a reappraisal. JAMA : the journal of the American Medical Association, v. 288, n. 9, p. 1116-24, 2002.

VELHO, M. T. A. DE et al. Residência Médica em Hospital Universitário: a Visão dos Residentes. Revista Brasileria de Educação Médica, v. 36, n. 3, p. 351-357, 2012.

WEBB, W. B.; FRIEL, J. Characteristics of "Natural" Long and Short Sleepers: A Preliminary Report. Psychological Reports, v. 27, n. 1, p. 63-66, 31 ago. 1970.

WONG, S. C. KEUNG; KO, A. Exploratory study of understanding hotel employees' perception on work-life balance issues. International Journal of Hospitality Management, 
v. 28, n. 2, p. 195-203, 2009.

ZERAATCHI, A. et al. Frequency and types of the medication errors in an academic emergency department in Iran: The emergent need for clinical pharmacy services in emergency departments. Journal of research in pharmacy practice, v. 2, n. 3, p. 118-22, 2013. 
ANEXO I- TERMO DE ANUÊNCIA DE INSTITUIÇÃO PARTICIPANTE 


\section{DECLARAÇÃO DE ANUÊNCIA E TERMO DE COMPROMISSO DA INSTITUIÇÃO CO-PARTICIPANTE}

Vimos pelo presente manifestar nosso apoio ao projeto de pesquisa objeto desse documento, coordenado pela Prof ${ }^{a}$. Dr ${ }^{a}$. Frida Marina Fischer, da Faculdade de Saúde Pública, da Universidade de São Paulo (FSP-USP), por entendermos que se trata de iniciativa que vem ao encontro dos esforços que temos desenvolvido neste Hospital das Clínicas da Faculdade de Medicina da Universidade de São Paulo (HCFMUSP) no sentido de melhor atender os Médicos Residentes, no que diz respeito às estratégias de conciliação entre sua vida pessoal e profissional.

Nestes termos, a Comissão de Residência Médica (COREME) do Hospital das Clínicas da Faculdade de Medicina da Universidade de São Paulo (HCFMUSP), representado pela sua Coordenadora, Prof $^{\mathrm{a}}$. Dr ${ }^{\mathrm{a}}$. Vera Hermina Kalika Koch, declara para os devidos fins e efeitos de direito que apoia e autoriza a realização da pesquisa abaixo citada, com os Médicos Residentes desse hospital:

- Identificação das estratégias para gestão do tempo entre vida pessoal e profissional de médicos residentes de um hospital público universitário de Säo Paulo, Brasil. Pesquisador responsável: Rafael Augusto Tamasauskas Torres, aluno de Mestrado da Faculdade de Saúde Pública da Universidade de Sảo Paulo (FSP-USP).

A COREME-HCFMUSP e a FSP-USP declaram que conhecem e que cumprirão os requisitos da Resolução $n^{\circ} 466$, de 12 de dezembro de 2012, do Conselho Nacional de Saúde, e suas complementares, e comprometem-se a utilizar os materiais e dados coletados exclusivamente para os fins previstos no protocolo da pesquisa acima descrita.

A COREME- HCFMUSP e a FSP-USP estão cientes que o propósito do estudo é contribuir para a elucidação de fatores que influenciam em patologias relacionadas à formação destes profissionais, incluindo a análise das complicaçōes devido as alteraçöes do ciclo sono-vigília, fatores psicossociais e ambientais, além de auxiliar na transformação das condições propiciadoras desses fatores, no sentido de prevenir o adoecimento desta população e dar melhores condiçōes de trabalho, assunto de relevância e interesse para o HCFMUSP.

São Paulo, 15 de agosto de 2016.

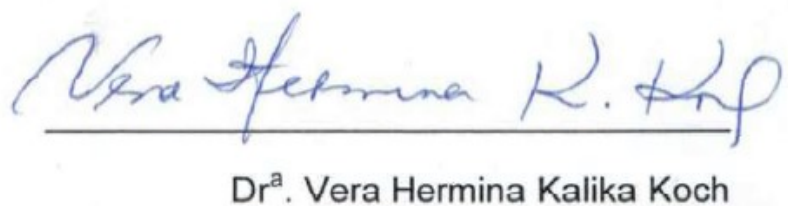

Coordenadora da COREME-HCFMUSP 
ANEXO II- PROTOCOLO DO COMITÊ DE ÉTICA EM PESQUISA 


\section{USP - FACULDADE DE SAÚDE PÚBLICA DA UNIVERSIDADE DE SÃO PAULO - FSP/USP}

\section{COMPROVANTE DE ENVIO DO PROJETO}

\section{DADOS DO PROJETO DE PESQUISA}

Título da Pesquisa: Identificação das estratégias para gestão do tempo entre vida pessoal e profissional de médicos residentes de um hospital público universitário de São Paulo, Brasil.

Pesquisador: Rafael Augusto Tamasauskas Torres

Versão: 2

CAAE: 62190916.0 .0000 .5421

Instituição Proponente:

Faculdade de Saúde Pública USP/SP

DADOS DO COMPROVANTE

Número do Comprovante:

$121135 / 2016$

Patrocionador Principal:

Financiamento Próprio

Informamos que o projeto Identificação das estratégias para gestão do tempo entre vida pessoal e profissional de médicos residentes de um hospital público universitário de São Paulo, Brasil. que tem como pesquisador responsável Rafael Augusto Tamasauskas Torres, foi recebido para análise ética no CEP USP - Faculdade de Saúde Pública da Universidade de São Paulo - FSP/USP em 21/11/2016 às 18:23.

Endereço: Av. Doutor Arnaldo, 715

Bairro: Cerqueira Cesar

CEP: $01.246-904$

UF: SP

Município: SAO PAULO

Telefone: (11)3061-7779

Fax: (11)3061-7779

E-mail: coep@fsp.usp.br 
ANEXO III- TERMO DE CONSENTIMENTO LIVRE E

ESCLARECIDO 
FACULDADE DE SAÚDE PÚBLICA/USP

TERMO DE CONSENTIMENTO LIVRE E ESCLARECIDO

DADOS DE IDENTIFICAÇÃO DO SUJEITO DA PESQUISA ( ${ }^{\circ}$

NOME:

DOCUMENTO DE IDENTIDADE No:

SEXO: M $\square$ F $\square$

DATA NASCIMENTO: 1

.$/$

ENDEREÇO

№

APTO:

BAIRRO:

CIDADE:

CEP:

TELEFONE: DDD (.......)

DADOS SOBRE A PESQUISA

1. TITULO DO PROTOCOLO DE PESQUISA: Identificação das estratégias para gestão do tempo no cotidiano de médicos residentes de Clínica Médica em um hospital público universitário de São Paulo

2.PESQUISADOR: DR. RAFAEL AUGUSTO TAMASAUSKAS TORRES

CARGO/FUNÇÃO: MÉDICO PRECEPTOR DO PROGRAMA DE RESIDÊNCIA MÉDICA EM MEDICINA LEGAL.

INSCRIÇÃO CONSELHO REGIONAL No 150.342

UNIDADE DA PESQUISA: FACULDADE DE SAÚDE PÚBLICA / COREME

3. AVALIAÇÃO DO RISCO DA PESQUISA: RISCO MÍNIMO

4.DURAÇÃO DA PESQUISA: 2 ANOS

Rubrica do participante:

Rubrica do pesquisador: 


\section{FACULDADE DE SAÚDE PÚBLICA/USP}

Este projeto tem como objetivo avaliar as estratégias de gestão do cotidiano de médicos residentes de Clínica Médica do Hospital das Clínicas da Universidade de São Paulo. Para tanto é necessária avaliação actimétrica (monitor de pulso semelhante há um relógio que acompanhará o participante por 15 dias consecutivos, o qual registra a amplitude e frequência dos movimentos do braço não dominante), avaliação da sonolência através de questionário, preenchimento de um relatório de atividades diárias (protocolo de atividades diárias), questionário de identificação de indivíduos matutinos ou vespertinos e entrevista semiestruturada, sendo estas avaliações realizadas em local e horário definido pelo residente participante. A entrevista será gravada através de um gravador digital e o conteúdo será confidencial. O material coletado pela gravação será transcrito, mantendo o anonimato e analisado durante o estudo.

Durante a execução do projeto, o participante, que fará adesão ao estudo de forma voluntária, terá como risco, por trata-se de uma população pequena e altamente específica, uma pequena, porém existente, possibilidade de identificação, através de dados gerais (por exemplo: residente do $2^{\circ}$ ano de Cirurgia, feminina, de 20 anos, do hospital estudado).

Como benefício, os participantes deste estudo os participantes serão informados sobre seu cronotipo e receberão um panorama geral de como suas atividades interferem em seu padrão de sono.

O pesquisador responsável é o Dr. Rafael Augusto Tamasauskas Torres, poderá ser encontrado no IOF- Instituto Oscar Freire, no Departamento de Medicina Legal, Ética Médica, Medicina Social e do Trabalho da FMUSP (Av. Dr. Enéas de Carvalho Aguiar, 255) ou no telefone (11) 9.5300-8804. Se você tiver alguma consideração ou dúvida sobre a ética da pesquisa, entre em contato com o Comitê de Ética em Pesquisa (CEP) da Faculdade de Saúde Pública - Av. Dr. Arnaldo, 715 - tel: 3061-7779 - email: coep@fsp.usp.br.

O participante tem garantida a liberdade de retirada deste estudo em qualquer momento da pesquisa.

As informações obtidas serão analisadas em conjunto com os outros participantes, não sendo divulgado a identificação de nenhum participante, os quais possuem o direito de serem mantidos atualizado sobre os resultados parciais da pesquisa.

Rubrica do participante: Rubrica do pesquisador: 


\section{FACULDADE DE SAÚDE PÚBLICA/USP}

Não há despesas pessoais para o participante em qualquer fase do estudo. Também não há compensação financeira relacionada à sua participação.

Há necessidade de consultá-lo para autorizar o uso deste material doado em outras pesquisas científicas?

(.....) SIM. Eu quero ser consultado para autorizar ou não cada pesquisa futura com o meu material.

(....) NÃO. Eu dispenso a autorização para cada pesquisa e estou informado (a) que a Comissão de Ética em Pesquisa irá examinar a nova pesquisa e decidir sobre a utilização ou não do material que eu estou doando.

Acredito ter sido suficientemente informado a respeito das informações que li ou que foram lidas para mim, descrevendo o estudo "Identificação das estratégias para gestão do tempo no cotidiano de médicos residentes de Clínica Médica em um hospital público universitário de São Paulo, Brasil".

Eu discuti com o Dr. Rafael Augusto Tamasauskas Torres sobre a minha decisão em participar nesse estudo. Ficaram claros para mim quais são os propósitos do estudo, os procedimentos a serem realizados, seus desconfortos e riscos, as garantias de confidencialidade e de esclarecimentos permanentes. Ficou claro também que minha participação é isenta de despesas. Concordo voluntariamente em participar deste estudo e poderei retirar o meu consentimento a qualquer momento, antes ou durante o mesmo, sem penalidades ou prejuízo ou perda de qualquer benefício que eu possa ter adquirido.

Data:

Assinatura do participante:

Declaro que obtive de forma apropriada e voluntária o Consentimento Livre e Esclarecido deste sujeito para participação neste estudo.

Assinatura do pesquisador responsável: 
ANEXO IV - ROTEIRO PARA ENTREVISTAS 


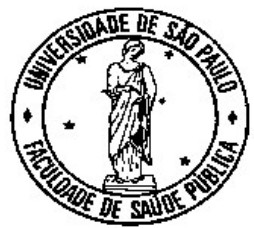

\section{Universidade de São Paulo - Faculdade de Saúde Pública \\ Pesquisa com Médicos Residentes \\ ROTEIRO DE ENTREVISTA}

\section{1) IDENTIFICAÇÃO DA ENTREVISTA}

Data da entrevista:

Hora de início:

Hora final:

Local de realização:

Endereço completo do informante e telefone para eventual contato posterior:

Comentários sobre a situação da entrevista (breve diário de campo):

\section{2) BREVE IDENTIFICAÇÃO DO ENTREVISTADO}

Nome:

ID:

Idade:

Sexo:

Estado civil:

Residência que está cursando:

Onde fez a graduação:

\section{3) CARACTERIZAÇÃO DA MORADIA E RENDA}

a) Onde você mora?

(Localização)

b) Possui mais de uma moradia? Se sim, fale mais sobre isso.

(Quanto tempo em cada uma? Qual o motivo? Localização da outra moradia)

c) Com quem você mora?

d) Qual sua renda mensal?

(Valor aproximado)

e) Explique a composição da sua renda?

( $\mathrm{x} \%$ bolsa da residência; $\mathrm{x} \% 1$ emprego; $\mathrm{x} \%$ outro emprego; $\mathrm{x} \%$ ajuda familiar)

f) Tem filhos ou algum dependente financeiro? (Se SIM, EXCLUSÃO DA PESQUISA) 
g) Recebe ajuda financeira de alguma pessoa? Se sim, de quem? Qual a participação desta pessoa na sua renda mensal?

h) Aproximadamente, como é dividido seus gastos mensais?

(explorar este ponto: $\mathrm{x} \%$ alimentação, $\mathrm{x} \%$ moradia, $\%$ atividades de lazer)

4) CARACTERIZAÇÃO DAS ATIVIDADES DESENVOLVIDAS NA RESIDÊNCIA MÉDICA

a) É a sua primeira residência médica? Se não, quais fatores levaram a realizar esta nova residência?

(Caracterizar se terminou a outra residência ou se não a concluiu e explorar as causas, tanto da escolha da nova residência quanto do não término da primeira, se aplicável)

b) Como são suas atividades diárias na residência?

c) Explique sua grade com um breve resumo dos seus estágios nestes dois anos de residência.

d) Há períodos programados para estudos durante as atividades práticas?

(Se possível, desenhar a grade)

e) Você realiza plantões noturnos pela residência médica? Se sim, quantos por semana? Quantas semanas no mês? Em quais estágios?

f) Você consegue descansar após realizar um plantão? Onde? Por quanto tempo?

g) Como é a qualidade deste repouso na sua opinião?

\section{5) CARACTERIZAÇÃO DE OUTRAS ATIVIDADES REMUNERADAS}

a) Você realiza outras atividades remuneradas fora a residência médica? Se sim, quais e como são os vínculos?

(Plantões? Ambulatórios? CLT? Caixa 2? PJ?)

b) Especifique as atividades desenvolvidas

(O que faz, quanto tempo, qual a frequência)

c) Nestas atividades estão inclusos plantões noturnos? Quantas vezes por semana?

d) Se sim, você consegue descansar após o plantão? Na sua opinião, como é a qualidade deste repouso? 


\section{6) MOBILIDADE, ATIVIDADES DOMÈSTICAS E DE LAZER}

a) Descreva as atividades desenvolvidas em um dia típico, incluindo o tempo gasto em transporte e locomoções.

(explorar tipo de transporte, tempo gasto no deslocamento, logística como um todo)

b) Quem cuida das atividades domésticas da sua moradia?

(Explorar limpeza e manutenção da casa, frequência, etc.)

c) Você cozinha? Com qual frequência?

d) Costuma almoçar em casa ou em restaurantes?

e) O que são atividades de lazer na sua opinião?

f) Você dedica parte de seu tempo a atividades de lazer?

g) Quais você costuma fazer?

h) Quantas horas por semana você dedica a atividades de lazer? [Especificar quais são as atividades de lazer para o entrevistado]

\section{7) RELACIONAMENTOS INTERPESSOAIS}

a) Você mora sozinho? Se não, quem mora com você?

b) Como é este relacionamento?

(Quantas horas passam juntos por dia/semana, quais as atividades que desempenham juntos, quais as responsabilidades de cada um nas atividades "do lar")

c) Você namora/é casado/solteiro/etc.? Há quanto tempo estão juntos? Como vocês se conheceram?

d) Quais atividades você realiza em conjunto com seu parceiro?

e) As atividades da residência ou outras remuneradas interferem de alguma forma neste relacionamento ou já interferiu em algum relacionamento passado? De que forma interfere/interferiu?

(tentar caracterizar a percepção sobre a influência, se positiva, negativa, neutra, se adaptado, possíveis angustias, etc.)

f) Quais são seus parentes mais próximos? Com quais mantem contato frequente? Como é a relação que você possui com eles? Quanto tempo por semana/mês você passa com estes parentes? Quais as atividades que vocês realizam em conjunto? 
g) Como é a relação que você possui com seus colegas de residência? Quanto tempo por semana/mês você passa com estes colegas? Quais as atividades que vocês realizam em conjunto?

h) Há algum colega de residência que participa do seu círculo de amigos íntimos? Se sim, descreva essa relação. Fale um pouco sobre seu círculo de amizades íntimas (quem são, quanto tempo dedica a estas amizades)?

\section{8) DETALHANDO ALGUMAS MUDANÇAS/INTERFERÊNCIAS}

a) Você acha que o início da residência trouxe mudanças para a sua rotina? Se sim, quais as principais diferenças da sua rotina antes e depois de iniciar a residência médica?

b) Como você avalia as mudanças do seu cotidiano com o início da residência médica?

c) Qual a sua opinião sobre o programa de residência médica quanto aos estágios programados?

d) Fale um pouco sobre a carga horária da residência.

e) Quais são seus planos após a conclusão da residência?

\section{9) FATORES QUE INFLUENCIAM NO SONO/SONOLÊNCIA}

a) Descreva o seu quarto e as condições em que ele se encontra nos momentos em que você pode dormir

(horários, luminosidade, ruído, interferência de outras pessoas)

b) Há locais adequados para o repouso durante os plantões realizados durante a residência médica?

c) Há locais adequados para o repouso durante os plantões realizados durante as outras atividades remuneradas?

d) Você sente-se descansado quando acorda em um dia sem plantão? E quando realiza plantões?

e) Você utiliza-se de café ou outra substância (chás, energéticos, medicamentos, drogas ilícitas) para manter-se acordado durante os plantões ou durante as atividades diárias? Se sim, fale mais sobre isso (tentar especificar qual, em quais momentos, com qual 
frequência) Se sim, há efeitos colaterais?

f) Você já dormiu sem conseguir controlar o sono? Se sim, em qual situação

(Investigar cochilos durante as aulas e caracterizá-los, cochilos enquanto dirigia, batidas de carro devido estes cochilos, cochilos durante atendimentos, etc.)

g) Alguma vez o sono pôs em risco sua atividade física ou profissional? Quando foi? Descreva a situação

h) Você já fez uso de alguma substância/medicação para induzir ou manter o sono? Se sim, qual, com qual frequência? Houve efeitos colaterais?

i) Você possui algum problema de saúde? Usa algum medicamento devido este problema?

j) Pratica atividade física? Se sim, qual, quantas vezes por semana, quanto tempo dura cada atividade e há quanto tempo faz esta modalidade.

Há algum aspecto referente a gestão do tempo das suas atividades pessoais e profissionais que você julgue importante que não foi abordado ao longo desta entrevista? 
ANEXO V - PROTOCOLO DE ATIVIDADES DIÁRIAS 
PESQUISA COM MÉDICOS RESIDENTES

CÓDIGO NA PESQUISA:

DATA:

DIA DA SEMANA:

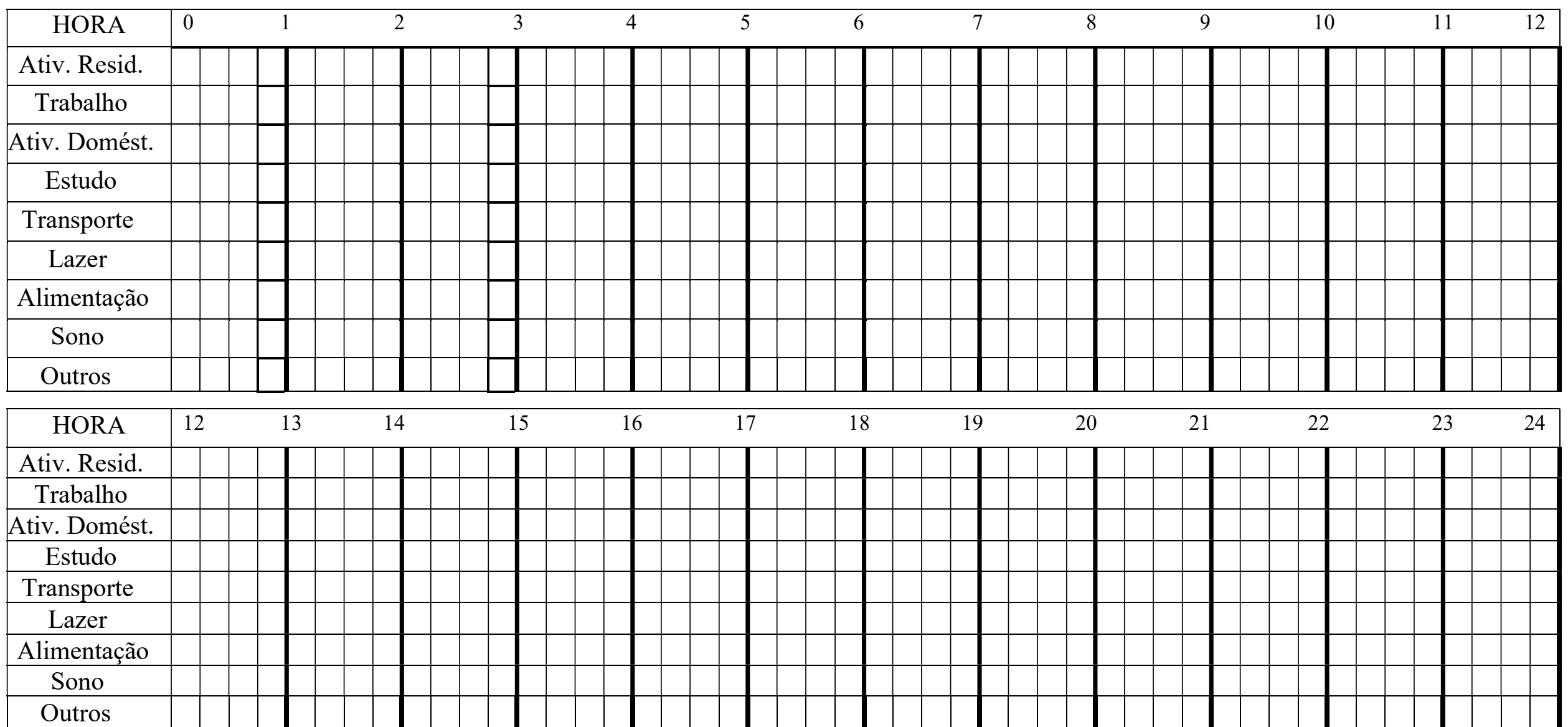

Como foi a qualidade do seu sono noturno?

Muito ruim

Como você sentiu-se ao acordar do seu sono noturno?

Muito ruim
Muito boa

Muito bem
Como foi a qualidade do seu sono diurno (caso se aplique)?

Muito ruim

Muito boa

Como você sentiu-se ao acordar do seu sono diurno (caso se aplique)?

Muito ruim

Muito bem 
